DANMARKS GEOLOGISKE UNDERSøGELSE

Serie B, Nr. 6

Geological Survey of Denmark. Series B, No. 6

\title{
Dinocyst stratigraphy of the latest Jurassic to Early Cretaceous of the Haldager No. 1 borehole, Denmark
}

BY

Roger J. Davey

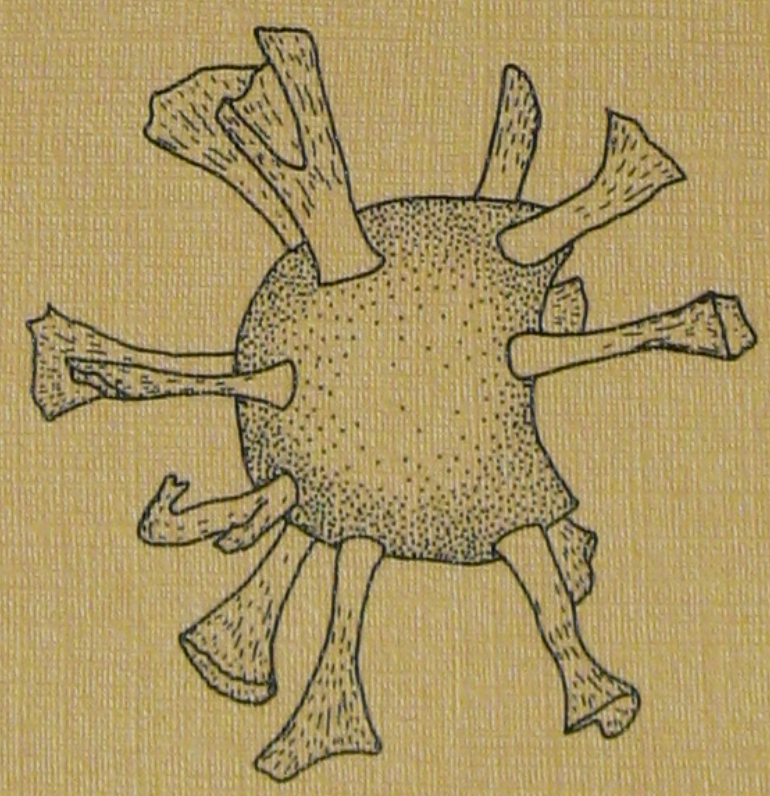

I kommission hos C. A. Reitzels Forlag. København 1982 
Danmarks Geologiske Undersøgelse. Serie B, Nr. 6

Geological Survey of Denmark. Series B, No. 6

\section{Dinocyst stratigraphy of the latest Jurassic to Early Cretaceous of the Haldager No. 1} borehole, Denmark

by

Roger J. Davey

I kommission hos C. A. Reitzels Forlag. København 1982 
D.G.U. Serie B, nr. 6

er sat med Foto Times og trykt i offset i 1000 eksemplarer hos AiO Tryk as, Odense

Bogen er trykt på Thai-Cote, $115 \mathrm{~g}$ fra a/s De forenede Papirfabrikker.

ISBN 87-421-0729-6

Date of publication 1982-07-30 


\section{Contents}

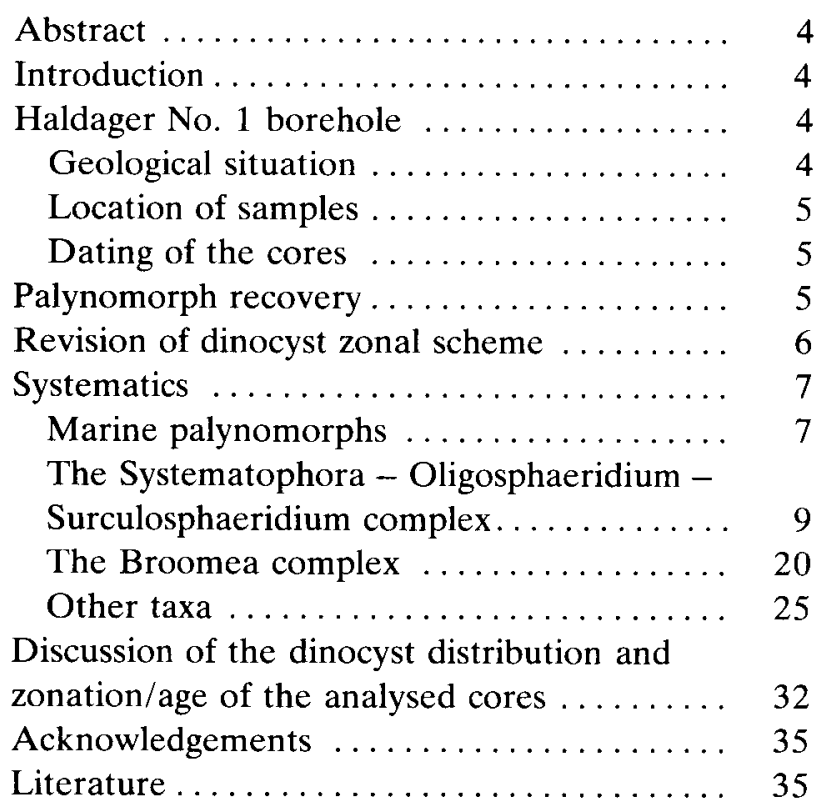




\section{Abstract}

The dinocyst assemblages were obtained from selected core samples, between the depths $2505^{\prime}$ and $3190^{\prime}$, from the Haldager No. 1 borehole, onshore Denmark. It has been possible to apply the dinocyst zonation of Davey (1979) to these assemblages and they have been dated as Hauterivian (Early Cretaceous) to early Portlandian (Late Jurassic). The placing of the Cretaceous-Jurassic boundary between 2945' and $2989^{\prime}$ differs significantly from its initial position in Sorgenfrei and Buch (1964) at 2706'. The present revised dating has subsequently been used by $\mathrm{Mi}-$ chelsen $(1978$, p. 23) in his study of the Norwegian Danish Basin. The study has necessitated the examination of many accurately dated samples of Early Cretaceous and Late Jurassic age from onshore eastern England and the results are incorporated in this paper. Detailed systematics, the key to a detailed stratigraphic breakdown, has necessitated the erection of 2 new genera (Cymososphaeridium and Stiphrosphaeridium), 12 new species and 2 new subspecies. In addition minor amendments are also made to the dinocyst zonation of Davey (op. cit.).

\section{Introduction}

The present investigation, although examining primarily the distribution of dinocysts in the latest Jurassic and Early Cretaceous of the Haldager No. 1 borehole, onshore Denmark, is part of a larger study dealing with rocks of these ages from the Boreal Province of northwest Europe. Thus, in this paper, reference is often made to onshore, accurately dated sections in eastern and southern England. The former include the classic exposure at Speeton, east Yorkshore (Neale, 1974), and the quarries and more temporary exposures in Lincolnshire and Norfolk (Casey, 1973). The sections in southern England include the type localities of the Kimmeridgian and Portlandian in Dorset (Torrens, 1969). Preliminary results of the stratigraphic distribution of dinocysts at this stratigraphic level, both in the Haldager No. 1 borehole and in England, are to be found in Davey (1979), where a formal dinocyst zonation was estab- lished. In the present paper recent data on the stratigraphic distribution of certain dinocysts and on the dating of some onshore English sections have neccessitated several revisions in the originally proposed zonation scheme. These are discussed below and the age of the interval examined from the Haldager No. 1 borehole, $2505^{\prime}-3190^{\prime}$, is reassessed accordingly.

\section{Haldager No. 1 borehole}

The Haldager No. 1 borehole was drilled by the Danish American Prospecting Co. (DAPCO.) during the later part of 1950 in northern Denmark to examine the Cretaceous and Jurassic (Sorgenfrei and Buch, 1964). Drilling commenced in a thin Pleistocene and a relatively complete Cretaceous and Jurassic succession was encountered. The borehole terminated in the Liassic at $4989^{\prime}(1521 \mathrm{~m})$ depth.

\section{Geological Situation}

The core samples analysed are from depths $2505^{\prime}$ to $3190^{\prime}$ (measured in feet below rotary table) and are of Early Cretaceous and Late Jurassic age. Sedimentation during these epochs took place in the Danish Sub-basin of the Norwegian-Danish Basin (Michelsen, 1978). This sub-basin was bordered by positive structural elements to the north and east, the Fennoscandian Shield, and to the south, the Ringkøbing-Fyn High. Seaways existed to the southeast, the Danish-Polish Trough, and to the west into the North Sea Basin. Most of the succession examined is assigned to the Bream Formation which is divided into two members. Only the upper one, the Frederikshavn Member $\left(2576^{\prime}-3374^{\prime}\right)$, was examined. The Frederikshavn Member is overlain by the Vedsted Formation of which only the basal part was analysed. During the deposition of the Bream Formation, Haldager was situated at or near the depocentre. 


\section{Location of Samples}

The upper part of the succession analysed, from $2505^{\prime}$ to $3009^{\prime}$, consists predominantly of silty clays and shales with minor siltstone. Between $3009^{\prime}$ and $3080^{\prime}$, sandstones and sands become dominant and below this level, down to $3190^{\prime}$, the lithology consists of clays, shales and silts with minor sands. (Additional, and more detailed, lithological information is to be found in the "Core Descriptions" of the Weekly Report of the Haldager No. 1 borehole obtainable from the Danish Geological Survey).

Although the interval analysed during this study was entirely cored, recovery was often poor and, as the cores have been moved and sampled several times, the exact positions of the analysed samples is usually only approximate. The following is a list of the cores analysed and the approximate position within the core of the actual core piece:-

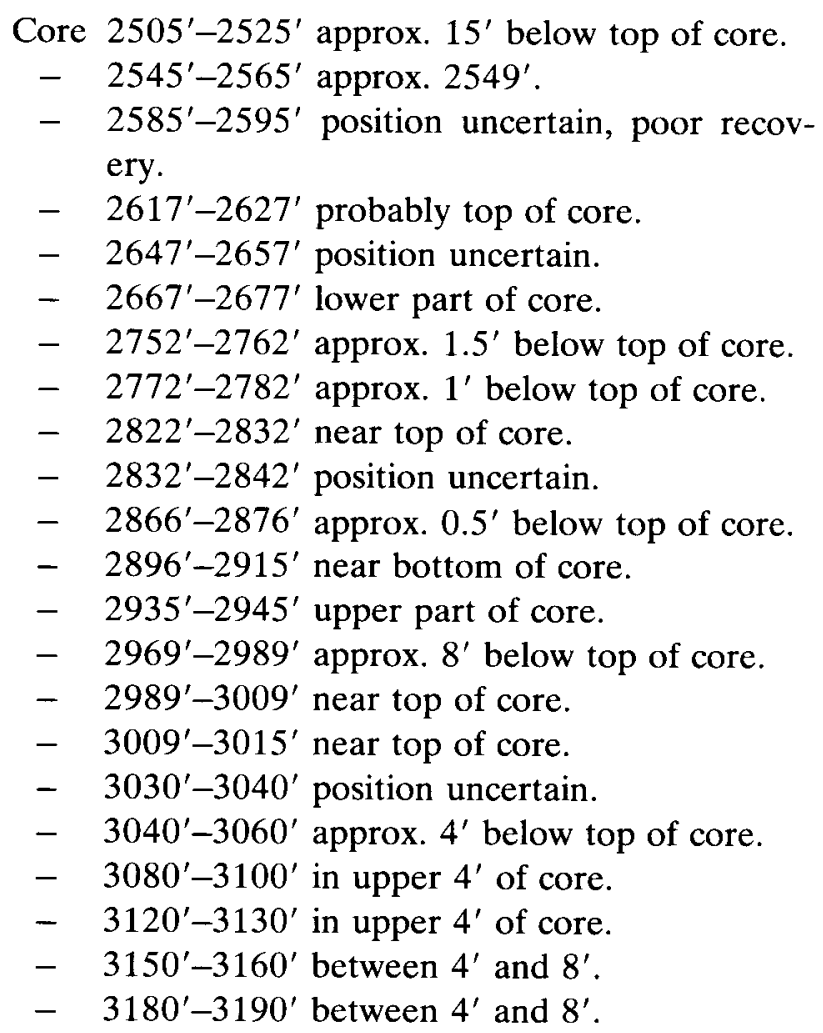

\section{Dating of the Cores}

The original stratigraphic account, in Sorgenfrei and Buch 1964, dated the Lower Cretaceous (1369'$\left.2706^{\prime}\right)$ and Portlandian $\left(2706^{\prime}-2950^{\prime}\right)$ on a combination of ammonites, pelycepods (Buchia) and benthonic foraminifera. These ages, and particularly the position of the Cretaceous-Jurassic boundary, were re-evaluated by Davey in 1976 (subsequently incorporated in Davey 1979) using dinocysts. These revised and more detailed datings were used by Michelsen (1978) in his account of the Jurassic of the Norwegian-Danish Basin and are discussed in the present paper.

\section{Palynomorph recovery}

Palynomorph recovery from seventeen of the nineteen core samples analysed was good. Two samples, at $2617^{\prime}-27^{\prime}$ and $3040^{\prime}-60^{\prime}$, proved to be barren. The latter is understandably barren as it is a fine grained sand which must have undergone winnowing during deposition. The reason for the former sample, a light grey silt, being barren is unclear. A third sample, at $2585^{\prime}-95^{\prime}$, contains downhole contamination and so has not been included in the detailed stratigraphic analyses.

Dinocyst recovery was generally good to very good and even in the poorest sample, at $3150^{\prime}-60^{\prime}$, a reasonable number of species are present. Acanthomorph acritarchs, consisting mainly of Micrhystridium Deflandre, 1937, are only common in the two youngest samples $\left(2505^{\prime}-25^{\prime}\right.$ and $\left.2545^{\prime}-65^{\prime}\right)$ although they are present throughout the analysed sequence. Miospores, of terrestrial derivation, are relatively common to very common in all the cores. Bisaccate pollen grains are typically relatively common in marine sediments but, in the present case, the relatively heavy pteridophyte spores are also consistently common. The latter characteristic is important and indicates strong terrestrial influence at the site of deposition and significant run-off from well vegetated landmasses bordering the depositional ba$\sin$. As would be expected terrestrically derived plant debris, in the form of woody material (humic) and plant cuticle, is the dominant kerogen component.

Obvious signs of reworking are uncommon and are indicated by Triassic species (Ovalipollis spp. and Ricciisporites tuberculatus Lundblad, 1954) at $2822^{\prime}-32^{\prime}$ and $2896^{\prime}-915^{\prime}$ and by the Liassic species Chasmatosporites magnolioides (Erdtman, 1948) at $2822^{\prime}-32^{\prime}$. In addition, there is some evidence to indicate minor reworking of Ryazanian to lower Valanginian sediments into the Hauterivian. Two occurrences illustrate this; firstly, the present of Occisucysta sp. A Davey, 1979, of early Valanginian to late Ryazanian age, at $2545^{\prime}-65^{\prime}$ and secondly, Aldorfia dictyota (McIntyre and Brideaux, 1980) comb. nov. at $2505^{\prime}-25^{\prime}$. 


\section{Revision of dinocyst zonal scheme}

The dinocyst zonal scheme for the Barremian to Portlandian, established by Davey 1979 , is here slightly modified because of recent changes in ammonite stratigraphy coupled with the reassessment of critical onshore sections and because of recent advances in our knowledge of dinocyst distribution and changes in taxonomy. Davey (op. cit., text-fig. 5) omitted detailed ammonite zonal schemes for the Barremian, Hauterivian and Valanginian and correlated his dinocyst zones/subzones directly to the Speeton Clay litho-units. This omission is here rectified in text-fig. 1. The Barremian and Hauterivian

\begin{tabular}{|c|c|c|c|c|}
\hline \multirow{2}{*}{\multicolumn{2}{|c|}{ AGE }} & \multirow{2}{*}{$\begin{array}{l}\text { BOREAL } \\
\text { AMMONITE } \\
\text { ZONES }\end{array}$} & \multicolumn{2}{|c|}{$\begin{array}{l}\text { DINOCYST ZONATION } \\
\text { (after Davey 1979) }\end{array}$} \\
\hline & & & SUBZONES & ZONES \\
\hline \multirow{4}{*}{ 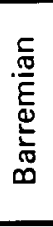 } & \multirow{4}{*}{ 츨 } & bidentatum & \multirow{2}{*}{$\begin{array}{c}\text { Palaeoperidinium } \\
\text { cretaceum }\end{array}$} & \multirow{3}{*}{$\begin{array}{c}\text { Odontochitina } \\
\text { operculata }\end{array}$} \\
\hline & & \multirow{2}{*}{ rude-fissicostatum } & & \\
\hline & & & Aptea anaphrissa & \\
\hline & & & $\frac{1}{2}$ & \multirow{3}{*}{$\begin{array}{l}\text { Subtilisphaera } \\
\text { terrula }\end{array}$} \\
\hline \multirow{7}{*}{ 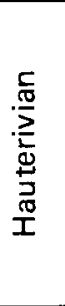 } & \multirow{3}{*}{ 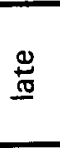 } & marginatus & \multirow{2}{*}{$\begin{array}{l}\text { Canningia cf. } \\
\text { reticulata }\end{array}$} & \\
\hline & & gottschei & & \\
\hline & & speetonensis & \multirow{3}{*}{$\begin{array}{l}\text { Batiodinium } \\
\text { Iongicornutum }\end{array}$} & \multirow{5}{*}{ Discorsia nanna } \\
\hline & \multirow{4}{*}{$\underset{\mathbb{E}}{\frac{Z}{\mathbb{E}}}$} & inversum & & \\
\hline & & regale & & \\
\hline & & noricum & \multirow{2}{*}{$\begin{array}{c}\text { Kleithriasphaeridium } \\
\text { simplicispinum }\end{array}$} & \\
\hline & & amblygonium & & \\
\hline \multirow{8}{*}{$\begin{array}{l}\frac{\sqrt{0}}{\sigma} \\
\frac{5}{\sigma} \\
\frac{\pi}{\pi} \\
>\end{array}$} & \multirow{6}{*}{ 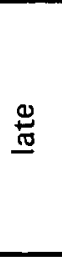 } & "Astieria" fauna & & \multirow{7}{*}{$\begin{array}{l}\text { Spiniferites } \\
\text { ramosus }\end{array}$} \\
\hline & & tuberculata* & & \\
\hline & & bidichotomoides ${ }^{*}$ & & \\
\hline & & triptychoides * & & \\
\hline & & pitrei & & \\
\hline & & Dichotomites spp. & & \\
\hline & \multirow{2}{*}{$\frac{7}{\frac{1}{8}}$} & Polyptychites & & \\
\hline & & Paratollia & & \multirow{2}{*}{$\begin{array}{l}\text { Pseudoceratium } \\
\text { pelliferum }\end{array}$} \\
\hline \multirow{5}{*}{ 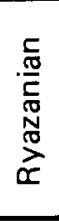 } & \multirow{3}{*}{ 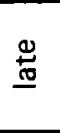 } & albidum & & \\
\hline & & stenomphalus & \multirow{2}{*}{ Scriniodinium pharo } & \multirow{9}{*}{$\begin{array}{l}\text { Gochteodinia } \\
\text { villosa }\end{array}$} \\
\hline & & icenii & & \\
\hline & 츤 & kochi & Cannosphaeropsis & \\
\hline & 0 & runctoni & & \\
\hline \multirow{8}{*}{ 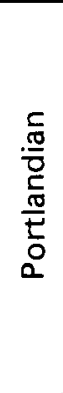 } & \multirow{3}{*}{ 离 } & lamplughi & \multirow{5}{*}{$\begin{array}{l}\text { Egmontodinium } \\
\text { expiratum }\end{array}$} & \\
\hline & & preplicomphalus & & \\
\hline & & primitivus & & \\
\hline & \multirow{5}{*}{$\frac{2}{\frac{1}{8}}$} & oppressus & & \\
\hline & & anguiformis & & \\
\hline & & kerberus & & $\begin{array}{l}\text { Dingodinium } \\
\text { spinosum }\end{array}$ \\
\hline & & glaucolithus & & Avellodinium \\
\hline & & albani & & culmulum \\
\hline
\end{tabular}

Fig. 1. Correlation of the dinocyst zonation to the Boreal ammonite zonation for the Portlandian to Barremian. 
ammonite zonal schemes are taken from Rawson et al. (1978) and the Valanginian scheme from Kemper et al. (in press). In addition, the revision of the early Portlandian ammonite zones by Wimbledon and Cope (1978) have also been incorporated into text-fig. 1.

In more detail, the following emendments have been made to the original ammonite zonation scheme used by Davey (op. cit.): I. It is not internationally agreed as to where the late-early Barremian boundary should be placed. At present, a "mid" interval is retained for practical purposes and is equivalent to the middle Barremian of Davey (op. cit.) and the Cement Beds of the Speeton Clay. For convenience, the late-early Barremian boundary has been placed at the top of the "mid" Barremian.

II. The position of the Barremian-Hauterivian boundary has been revised by Kemper et al. (in press) and is now placed at the base of the variabilis Zone which is equivalent to the base of the litho-unit $\mathrm{C} 2 \mathrm{C}$ in the Speeton Clay. Davey (op. cit.) and Rawson et al. (1978) had previously placed it at the top of this zone, that is at the base of the litho-unit LB5D. III. The late-early Hauterivian boundary is placed in the upper part of the inversum Zone (Kemper et al., in press).

IV. The upper portion of the Valanginian is represented by a remanié horizon in the Speeton Clay at Speeton and for this reason three German ammonite zones have been utilised at this stratigraphic level.

The majority of the changes made to the dinocyst zonal scheme of Davey (op. cit.) involve taxonomic changes - the reattribution of species to different genera and the erection of new species. These are as follows:

Palaeoperidinium cretaceum substituted for Astrocysta cretacea.

Aptea anaphrissa substituted for Doidyx anaphrissa. Nexosispinum vetusculum substituted for Adnatosphaeridium vetusculum.

Scriniodinium pharo substituted for Endoscrinium pharo.

Gochteodinia villosa substituted for Pareodinia dasyforma.

Cannosphaeropsis thula sp. nov. to replace Cannosphaeropsis sp. A.

Egmontodinium expiratum sp. nov. to replace $E g-$ montodinium sp. A.

The definition of only one subzone is here changed and the lower boundary moved down slightly. This change involves the Chlamydophorella trabeculosa Subzone, the lower boundary of which was defined as the first stratigraphic appearance of the nominative species which was considered to be at the base of the
Speeton Clay litho-unit C9, in the middle of the regale ammonite Zone. Forms that are attributable to, or at least could be easily confused with, $C$. trabeculosa have recently been observed in the early Hauterivian and Valanginian. Thus, the use of this species in a zonation scheme is obviously not desirable and the distinctive species Batioladinium longicornutum has been substituted. The first stratigraphic occurrence of this species is marginally lower, at the base of the regale ammonite Zone and at the base of the C11 litho-unit in the Speeton Clay. The upper boundary of the $B$. longicornutum Subzone remains the same as that of the former $C$. trabeculosa Subzone. The difinition of the $B$. longicornutum Subzone is as follows:- "The interval from the first appearance of Batioladinium longicornutum to the first appearance of Subtilisphaera terrula. Age - early to late Hauterivian (C11 to C7F litho-units, Speeton Clay, Speeton).

\section{Systematics}

The following section is divided into four parts. The first lists, in alphabetical order, all marine palynomorphs encountered during the present study and indicates, where appropriate, the plates on which they are figured. Figures in brackets refer to the position of that palynomorph on text-fig. 3. New species or those that require certain amplifying remarks are indicated by an asterisk (*) and are dealt with in parts two to four. Parts two and three deal with two groups of related genera - the Systematophora, Oligosphaeridium and Surculosphaeridium complex and the Broomea complex. The final section treats all forms not included in these complexes.

All type material has been assigned MPK numbers and is housed with all the slides examined in this study, in the palynologic slide collection at the Institute of Geological Sciences, Leeds, England. A representative set of slides is also housed at the Danish Geological Survey, Copenhagen.

\section{Marine Palynomorphs}

Acanthomorph acritarchs (1)

Achomosphaera neptuni (Eisenack, 1958) Davey \& Williams, 1966a (83)

A. cf. neptuni (Eisenack, 1958) Davey \& Williams, 1966a, in Davey \& Verdier, 1974 (105)

*Aldorfia dictyota (Cookson \& Eisenack, 1960b) comb. nov. (63) 
*A. spongiosa (McIntyre \& Brideaux, 1980) comb. nov. Pl. 7, figs. 7-10 (55)

Aldorfia sp. A, Pl. 7, figs. 13-15

Aprobolocysta neistosa Duxbury, 1980, P1. 7, figs. 5-7 (52)

*Apteodinium sp. A, Pl. 7, figs. 11, 12, 16 (46)

Athigmatocysta grabra Duxbury, 1977 (65)

*Avellodinium culmulum (Norris, 1965) comb. nov. (16)

A. falsificum Duxbury, 1977 (53)

* Batioladinium longicornutum (Alberti, 1961) Brideaux, 1975 (106)

${ }^{*} B$. pomum sp. nov. Pl. 5, figs. 2-4 (59)

${ }^{*} B$. radiculatum sp. nov. Pl. 5, figs, 1, 7-9 (60)

*B. varigranosa Duxbury, 1977, Pl. 5, figs. 5, 6 (102)

${ }^{*} B$. cf. varigranosa Duxbury, 1977, Pl. 5, fig. 10 (62)

* Batioladinium sp. I, Pl. 5, figs. 11-13

Caddasphaera halosa (Filatoff, 1975) Fenton, Neves \& Piel, 1980 (2)

Callaiosphaeridium cf. asymmetricum (Deflandre \& Courteville, 1939) Davey \& Williams, 1966b (122)

* Canningia compta sp. nov. P1. 8, figs. 3-6 (11)

*Cannosphaeropsis thula sp. nov. Pl. 8, figs. 7-11 (19)

*Cantulodinium speciosum Alberti, 1961, Pl. 4, fig. 11 (71)

Cassiculosphaeridia magna Davey, 1974 (31)

C. reticulata Davey, 1969a (94)

*Chlamydophorella membranoidea Vozzhennikova, 1967, Pl. 8, fig. 12 (41)

C. trabeculosa (Gocht, 1959) Davey, 1978 (107)

Chlamydophorella spp. (87)

Cleistosphaeridium tribuliferum (Sarjeant, 1962a)

Davey et al., 1969 (21)

Cleistosphaeridium spp. (3)

Cometodinium whitei (Deflandre \& Courteville, 1939) Stover \& Evitt, 1978 (76)

Cribroperidinium edwardsii (Cookson \& Eisenack, 1958) Davey, 1969a (118)

*Cribroperidinium sp. A, Pl. 10, figs. 5, 6 (37)

Cribroperidinium spp. (66)

Ctenidodinium elegantulum Millioud, 1969 (84)

Cyclonephelium hystrix (Eisenack, 1958) Davey, 1978 (4)

Cyclopsiella sp. (58)

*Cymososphaeridium validum sp. nov. Pl. 3, figs. 5, 6, 8, 11 (108)

Cymososphaeridium sp. I, Pl. 3, figs. 9, 12

*Dichadogonyaulax pannea (Norris, 1965) Sarjeant, 1969. Pl. 9, fig. 10 (22)

Dingodinium albertii Sarjeant, 1966c (32)

D. minutum Dodekova, 1975. (12)

D. spinosum (Duxbury, 1977) Davey, 1979 (47)
Discorsia nanna (Davey, 1974) Duxbury, 1977 (109)

*Egmontodinium expiratum sp. nov. Pl. 8, figs. 13-16 (39)

E. ovatum (Gitmez \& Sarjeant, 1972) Riley, 1979, Pl. 10, figs. 1, 2 (27)

E. polyplacophorum Gitmez \& Sarjeant, 1972 (23)

E. torynum (Cookson \& Eisenack, 1960b) Davey 1979 (35)

Ellipsoidictyum cinctum Klement, 1960 (38)

Exiguisphaera phragma Duxbury, 1979 (88)

Exochosphaeridium phragmites Davey et al., 1966 (110)

Fromea amphora Cookson \& Eisenack, 1958 (73)

Glossodinium dimorphum Ioannides et al., 1977 (40)

*Gochteodinia mutabilis (Fisher \& Riley, 1980) comb. nov. Pl. 6, figs. 9, 12 (26)

*G. villosa (Vozzhennikova, 1967) Norris, 1978. Pl. 6 , figs. 1, 4-6 (45)

${ }^{*} G$. villosa subsp. multifurcata nov. Pl. 6, fig. 13 (80)

${ }^{*} G$. virgula sp. nov. Pl. 6, figs. 2, 3, 7, 8, 10, 11 (51)

*Gochteodinia sp. I, P1. 6, figs. 14, 15 (49)

*Gochteodinia sp. II, Pl. 7, figs. 1-4

Gonyaulacysta helicoidea (Eisenack \& Cookson, 1960) Sarjeant, 1966b (5)

G. ordocava Duxbury, 1977 (123)

G. pennata Fisher \& Riley, 1980 (14)

*Gonyaulacysta sp. A, Davey, 1979. Pl. 10, fig. 3 (61)

*Gonyaulacysta sp. B (81)

Heslertonia heslertonensis (Neale \& Sarjeant, 1962) Sarjeant, 1966b (95)

H. pellucida Gitmez, 1970 (77)

Hystrichodinium furcatum Alberti, 1961 (124)

H. pulchrum Deflandre, 1935 (6)

H. voigtii (Alberti, 1961) Davey, 1974 (42)

*Hystrichogonyaulax cf. cladophora (Deflandre, 1938b) Stover \& Evitt, 1978, Pl. 10, fig. 7 (111)

Hystrichogonyaulax spp (7)

Hystrichosphaeridium cf. arborispinum Davey \& Williams, 1966b (101)

$H$. cf. recurvatum (White, 1842) Davey \& Williams, 1966b. Pl. 10, fig. 4 (125)

*Hystrichosphaerina schindewolfii Alberti, 1961. (89)

Isthmocystis distincta Duxbury, 1979. Pl. 8, figs. 1, 2 (43)

Kleithriasphaeridium corrugatum Davey, 1974 (28)

K. fasciatum (Davey \& Williams, 1966b) Davey, 1974 (67)

*K. porosispinum sp. nov. Pl. 10, figs. 8-12. (17)

K. simplicispinum (Davey \& Williams, 1966b) Davey, 1974 (90)

Lagenorhytis delicatula (Duxbury, 1977) Duxbury, $1979(92)$ 
Lecaniella foveata Singh, 1971 (30)

Lithodinia bulloidea (Cookson \& Eisenack, 1960b) Lentin \& Williams, 1977 (74)

?Maduradinium sp. A Davey, 1978 (85)

Millioudodinium sp. A (18)

Mendicodinium groenlandicum (Pocock \& Sarjeant, 1972) Davey, 1979 (15)

Muderongia crucis Neale \& Sarjeant, 1962 (119)

M. extensiva Duxbury, 1977 (120)

M. simplex Alberti, 1961 (68)

* $M$. simplex subsp. microperforata nov. Pl. 9, figs. 4-6 (82)

*Muderongia sp. A sensu Davey, 1979. Pl. 9, figs. 1-3. (25)

*Muderongia sp. B (121)

Nelchinopsis kostromiensis (Vozzhennikova, 1967) Wiggins, 1972 (112)

Nematosphaeropsis scala Duxbury, 1977 (113)

Occisucysta tentoria Duxbury, 1977. Pl. 9, figs 13, 14 (86)

*Occisucysta sp. A Davey, 1979. Pl. 10, figs. 14, 15 (57)

* Oligosphaeridium asterigerum (Gocht, 1959) Davey \& Williams, 1969, Pl. 1, fig. 12 (103)

O. complex (White, 1842) Davey \& Williams, 1966b (114)

${ }^{*} O$. diluculum sp. nov. P1. 2, figs. 1-5 (70)

${ }^{*}$ Oligosphaeridium sp. I, Pl. 2, figs. 6-8

Ophiobolus sp. A Davey, 1979 (96)

*Pareodinia sp. I, Pl. 4, figs. 12-14 (75)

Pareodinia spp. (29)

*Perisseiasphaeridium insolitum sp. nov. Pl. 4, figs. 8-10 (50)

Phoberocysta neocomica (Gocht, 1957) Millioud, 1969 (99)

P. tabulata Raynaud, 1978 (97)

*Polygonifera staffinensis (Gitmez, 1970) comb. nov. (24)

Polysphaeridium warrenii Habib, 1976 (98)

Pseudoceratium pelliferum Gocht, 1957. Pl. 10, fig. $16(78)$

Pterospermella aureolata (Cookson \& Eisenack, 1958) Eisenack, 1972 (36)

*Pterospermella sp. A (54)

Pterospermella spp. (79)

Scriniodinium campanulum Gocht, 1959. Pl. 9, figs. $11,12(91)$

*S. pharo (Duxbury, 1977) comb. nov. (13)

Sirmiodinium grossii Alberti, 1961 (9)

Spiniferites ramosus (Ehrenberg, 1838) Loeblich \& Loeblich, 1966 (100)

S. ramosus (Ehrenberg, 1838) subsp. primaevus Duxbury, 1977. Pl. 9, figs. 7, 8 (113)
*Stiphrosphaeridium arbustum sp. nov. Pl. 3, figs. $1-4(72)$

${ }^{*} S$. dictyophorum (Cookson \& Eisenack, 1958) comb. nov. Pl. 2, figs. 10-13 (64)

*Surculosphaeridium sp. I, Pl. 3, figs. 7, 10 (104)

*Surculosphaeridium sp. II, Pl. 4, figs. 1, 2

*Surculosphaeridium sp. III, Pl. 4, figs. 3-6

* Systematophora cf. areolata Klement, 1960, PI. 1, figs. 5, 6 (10)

*S. palmula sp. nov. Pl. 1, figs. 1-4 (56)

S. silyba Davey, 1979 (116)

*Systematophora sp. I, Pl. 1, figs. 7-9 (20)

*Systematophora sp. II, Pl. 1, figs. 10, 11 (93)

Tanyosphaeridium boletum Davey, 1974 (117)

Tanyosphaeridium spp. (44)

*Tasmanites newtoni Wall, 1965 (48)

Trichodinium ciliatum (Gocht, 1959) Eisenack, 1964 (33)

Tubotuberella apatela (Cookson \& Eisenack, 1960b) Ioannides et al. 1977 (34)

Wallodinium spp. (69)

\section{The Systematophora - Oligosphaeridium - Surculosphaeridium complex}

\section{Discussion}

The species included within these three genera have in common that they are all skolochorate, gonyaulacacean cysts having an apical archaeopyle and possessing not more than one process or process group per paraplate. Generic differentiation depends on process morphology, i.e. annulate-arcuate, hollow or solid, how the various types are combined, upon the process formula (particularly the presence or absence of paracingular processes) and the presence of ring and linking trabeculae. Thus it is theoretically possible to define many genera using various combinations of the above criteria. The presence of ring trabeculae, either completely or partly linking the distal ends of the processes in annulate complexes, or the distal furcations of solid, fenestrate processes, is used solely at the generic level to differentiate Hystrichosphaerina Alberti 1961 from Systematophora Klement 1960 . This morphological criterion is usually easy to use although, in some instances, adherence to it may cause controversial results as when two morphologically related forms, $S$. fasciculigera Klement 1960 and $H$. orbifera (Klement) Stover and Evitt 1978, are placed in different genera. The linking of processes or process groups by trabeculae, however, as in Emmetrocysta Stover 1975 and the »Adnatosphaeridium « aemulum (Deflandre 1938) 
complex, is considered to be of greater generic value. A summary of the process arrangements and types in the genera belonging to this complex is shown on table 1 . Seven of the genera are already in existence and two new genera, Stiphrosphaeridium and Cymososphaeridium, are here erected.

The Systematophora - Oligosphaeridium - Surculosphaeridium complex is not considered to be a simple lineage in which one genus simply evolves from another and in time gives rise to a further one. More realistically, the basic Systematophora type must be regarded as a root stock from which, at certain times in the past, evolved certain variants or morphotypes that are now assigned to different genera. Hence the Oligosphaeridium species (described as $O$. pulcherrium, by Ioannides et al. 1977 , herein pl. 2, fig. 9) from the mid-Kimmeridgian evolved from the Systematophora root stock but did not give rise directly to $O$. complex in the Valanginian. Sometimes associated with this Kimmeridgian Oligosphaeridium, and probably closely related to it, is a form here referred to Perisseiasphaeridium sp. I (pl. 4 , fig. 7) which has solid, paracingular processes. $O$. complex, in all probability, arose from the Systematophora root stock in the Ryazanian - early Valanginian perhaps through an intermediate species (see fig. 2). Similarly Surculosphaeridium cribrotubiferum (Sarjeant 1960) arose in the Oxfordian probably from ancesters attributable to Systematophora. Morphotypes attributable to Surculosphaeridium did not reappear until the Valanginian, again probably from a Systematophora stock.

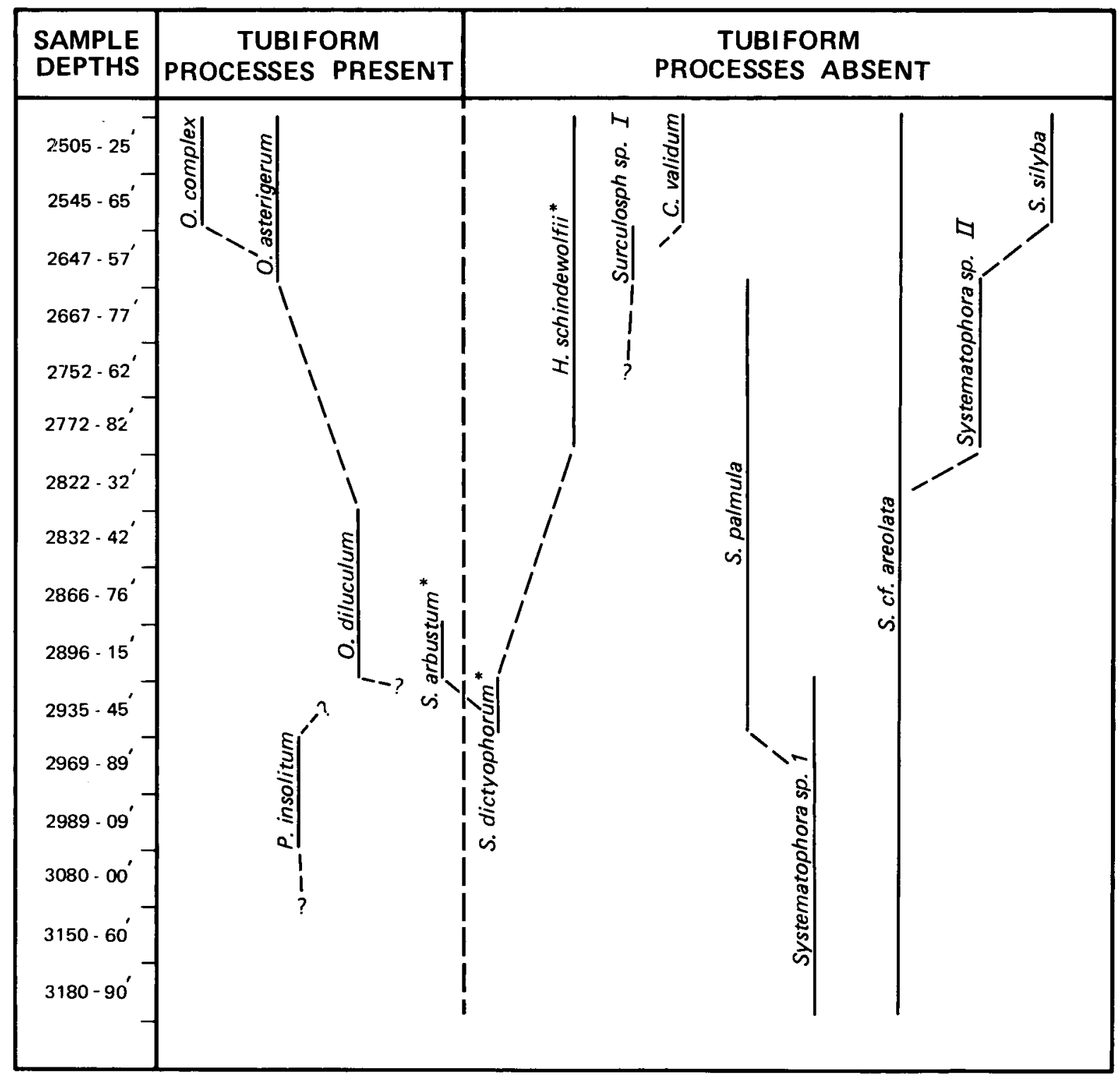

* Ring Trabeculae

Fig. 2. The ranges of certain chorate dinocysts in the Haldager No. 1 borehole. 
Table 1. Summary of the morphological characteristics of similarly structured chorate dinocysts

\begin{tabular}{|c|c|c|c|c|}
\hline Genera & $\begin{array}{l}\text { Pre- and } \\
\text { postcingular } \\
\text { process type }\end{array}$ & $\begin{array}{l}\text { Ring } \\
\text { trabeculae }\end{array}$ & $\begin{array}{l}\text { Linking trabeculae } \\
\text { between processes/ } \\
\text { process complexes }\end{array}$ & $\begin{array}{l}\text { Paracingular } \\
\text { process type }\end{array}$ \\
\hline Systematophora & $\begin{array}{l}\text { Annulate-arcuate } \\
\text { complexes }\end{array}$ & Absent & Absent & Solid \\
\hline Oligosphaeridium & Tubiform & Absent & Absent & Absent \\
\hline Surculosphaeridium & Solid & Absent & Absent & Solid \\
\hline Stiphrosphaeridium & $\begin{array}{l}\text { Solid-restricted } \\
\text { annulate complexes }\end{array}$ & Present & Absent & Absent \\
\hline Hystrichosphaerina & $\begin{array}{l}\text { Solid?-restricted } \\
\text { annulate complexes }\end{array}$ & Present & Absent & $\begin{array}{l}\text { Solid } \\
\text { (rarely absent) }\end{array}$ \\
\hline Cymososphaeridium & Solid & Absent & Absent & Absent \\
\hline Perisseiasphaeridium & Tubiform & Absent & Absent & Solid \\
\hline Hystrichosphaeridium & Tubiform & Absent & Absent & Tubiform \\
\hline Emmetrocysta & Annulate complexes & Present & Present & Absent \\
\hline $\begin{array}{l}\text { "Adnatosphaeridium } \\
\text { aemulum complex }\end{array}$ & $\begin{array}{l}\text { Solid-annulate } \\
\text { complexes. Rarely } \\
\text { tubiform }\end{array}$ & Present & Present & Absent \\
\hline Polystephanephorus & Annulate complexes & Present & Present & Solid \\
\hline
\end{tabular}

\section{Genus Systematophora Klement 1960}

Description. The genus Systematophora is characterised by annulate complexes of processes which are best developed in the pre-, postcingular and antapical regions; a single complex occupies each paraplate. When well developed the annulate complexes are penitabular in position but often their size is reduced and they become circular and occupy the central part of the individual paraplate. An additional trend is for the basal ridge of the pre-and postcingular complexes to become reduced on the paracingular margin and the processes to the concentrated on the side of the ridge opposite this margin. In other forms the basal ridge is absent and the individual processes appear to arise immediately from the cyst wall.

The processes are solid, although internal vacuoles may be present; they may be completely separate as in $S$. areolata Klement 1960 , the type species, or may be linked to neighbouring processes in the complex by a few simple branches or by numerous branches so that a intricate network is developed. All intermediates extist between isolated processes and simple and intricately linked processes. Restricted annulate complexes, composed of two to three individual processes, may develop in the apical region but often here one paraplate bears a single process. This also happens on the parasulcus and on paraplate $1^{\prime \prime \prime}$. Two linearly arranged processes usually occupy each cingular paraplate. The process formula appears to be $4^{\prime}, 6^{\prime \prime}, 5-6 \mathrm{c}, 6^{\prime \prime \prime}, 1 \mathrm{p}, 1^{\prime \prime \prime}, 1-5 \mathrm{~s}$. The ar- chaeopyle is apical, formed by the detachment of four apical paraplates as a unit (Type $\bar{A}$ ).

Remarks. The holotype of Polystephanephorus calathus (Sarjeant 1961a) Downie and Sarjeant 1965, which is the type species of the genus, has been reexamined and possesses paracingular processes of the Systematophora - type. This is considered to be an important morphological criterion and suggests that Polystephanephoros Sarjeant 1961b is closely related to Systematophora. Polystephanephoros is distinguished from Systematophora by having trabeculae which distally link the process complexes.

\section{Systematophora palmula sp. nov}

Pl. 1, figs. $1-4$

Derivation of name. Latin, palma, hand - with reference to the shape of the major processes.

Diagnosis. Shape. The body was originally spheroidal with only minor dorso-ventral flattening.

Wall. The cyst wall is of moderate thickness and is apparently two-layered, the two layers being closely appressed except where the periphragm alone forms the processes. It is smooth to scabrate. The processes are smooth and may have internal vacuoles.

Processes. These are basically of two types - the pre-, postcingular and antapical annulate processes being membranous and the apical, parasulcal and paracingular processes being simple. The proximal 
ridges of the annulate complexes tend to be arcuate and, in the pre- and postcingular series, are best developed on the side away from the paracingulum. The single membranous process arising from this arcuate ridge divides medially into two or more branches; additional branching may be present and the distal termination is a small bifurcation. The parasulcal processes are unbranched and solid; they gradually taper-distally to terminate with a small bifuration. The apical processes are similar or slightly membranous. The paracingular processes occur in pairs, two per paraplate, and each pair may be linked proximally by a ridge.

Archaeopyle. An apical archaeopyle always appears to be developed by the detachment of the apical paraplates as a unit (Type $\overline{\mathrm{A}}$ ). It has a strongly zigzag margin.

Holotype. MPK 2608, slide SAL 4639/III, Haldager No. 1 borehole, core depth 2896'-2915', Denmark. Ryazanian, Early Cretaceous.

\section{Dimensions}

Body diameter

(excluding processes)

Length

(archaeopyle developed)

width

Process length

$\begin{array}{cc}50 & 34(45) 53 \\ 44 & 39(43) 48 \\ 18-38 & 20-38\end{array}$

Description. The width of the membranous processes varies considerably upon an individual specimen and from specimen to specimen. The largest ones, in the antapical and dorsal postcingular positions, divide medially into four to seven subparallel branches; the remaining postcingular processes and the precingular processes are less divided, typically two to four branches, and the division may commence in the lower part of the process.

Remarks. The membranous nature of the major processes in S. palmula sp. nov. distinguishes this species from all previously described forms. When some of the major processes become deeply divided, as is sometimes the case, they tend to resemble the larger annulate complexes of $S$. cf. areolata, indicating that the two forms are morphologically related.

Occurrence. S. palmula sp. nov. is consistently present from $2935^{\prime}-45^{\prime}$ to $2667^{\prime}-77^{\prime}$ (Ryazanian to Valanginian), Haldager No. 1 borehole. It also occurs in the albidum (late Ryazanian) and Paratollia spp. (early Valanginian) Zones of the Speeton Clay.
Systematophora cf. areolata Klement 1960

Pl. 1, figs. 5, 6

Remarks. The present specimens are very similar to the type material from the Lower Kimmeridgian of Germany from which they may be distinguished by, i) the processes being more variable in that they occasionally branch and maybe linked medially or proximally, and, ii) the proximal ridges of the annulate complexes that are subpolygonal in $S$. areolata are reduced to either circular or arcuate ridges, or are apparently absent altogether in $S$. cf. areolata.

Occurrence. S. cf. areolata occurs in most of the Haldager No. 1 borehole samples and in eastern and northeastern England occurs infrequently in the late Ryazanian and early Valanginian (bed D4, Speeton).

\section{Systematophora sp. I}

Pl. 1, figs. 7-9

Description. The cyst is subcircular in outline and is composed of a more or less smooth wall. The anulate complexes are variably developed and proximally usually have a circular ridge from which arise the solid processes. The antapical annulate complex is well developed but in the pre- and postcingular regions the processes tend to be concentrated on the side of the ridge away from the paracingular region. One broad to several finer processes arise from each complex and these divide medially to give several branches which tend to be linked distally by a trabeculum; the trabeculum is arcuate, not circular, in the pre-and postcingular series because of the paucity of processes on the paracingular side of each complex. Alternatively, a process may broaden distally to form a "pseudo-trabeculum" which parallels the cyst surface (pl. 1, figs. 7). The outer margins of the trabeculae bear small spines. The trabeculae and pseudo-trabeculae are formed within an annulate complex and there is no linkage between neighbouring complexes. The apical, cingular and sulcal processes do not form annulate complexes and usually simply branch distally.

Remarks. A reasonable amount of variation as to complexity of process branching has been taken as being acceptable in Systematophora sp. I. This variation appears to be continuous and, for the present, there does not seem to be a practical way of subdividing this species. It is characterised by clearly defined pre- and postcingular annulate complexes which distally form arcuate trabeculae or psuedotrabeculae that are distally spiny. 
The most similar species to Systematophora sp. I appears to be Adnatosphaeridium caulleryi (Deflandre) Williams and Downie 1969 which has finer processes and more extensive trabeculae. If true trabeculae are absent from $A$. caulleryi then Systematophora sp. I may fall within the range of variation acceptable for this species. Hystrichosphaerina orbifera (Klement) Stover \& Evitt 1978 is basically similar to Systematophora sp. 1 but has considerably more complexly branched processes and the distal trabeculae are typically complete.

Occurrence. Systematophora sp. I is very rare in core $2935^{\prime}-2945^{\prime}$ (Ryazanian) but is common to moderately common in all the underlying cores of Haldager No. 1. It is moderately common in the early Ryazanian (kochi and runctoni Zones) of eastern England and becomes common in the Portlandian and Kimmeridgian of this region and southern England.

\section{Systematophora sp.II}

P1. 1, figs. 10, 11

Description. This subspherical cyst has a slightly to heavily granular wall and rather poorly defined annulate complexes. The proximal ridges of the complexes are rarely developed and the processes tend to be concentrated on the side of the complexes away from the paracingulum. The processes are short, less than half the cyst diameter and are of variable width. The broader ones widen distally to terminate with small spines; the narrow processes terminate with a simple bifurcation. The processes are not branched or linked by trabeculae.

Dimensions. Body diameter (excluding processes);

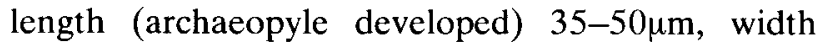
$40-52 \mu \mathrm{m}$; maximum length of processes $13-19 \mu \mathrm{m}$.

Remarks. The granular wall, poorly defined annulate complexes and relatively short, broad, processes differentiate Systematophora sp. II from S. cf. areolata.

Occurrence. This form was only recovered in cores $2752^{\prime}-62^{\prime}$ to $2772^{\prime}-82^{\prime}$ (early Valanginian) Haldager No. 1 borehole, where it was common to abundant.

\section{Other species}

The genus Surculosphaeridium is below (p. 16) restricted to species having one process per paraplate in the pre-, postcingular and antapical series. Hence the following species no longer belongs in this genus and is here transferred to Systematophora.

Systematophora vestitum (Deflandre) Davey comb. nov. = Hystrichosphaeridium vestitum Deflandre, 1938, p. 189, pl. 11, figs. 4-6. Lower Oxfordian, France.

Genus Oligosphaeridium Davey and Williams 1966b emend.

Type species. Oligosphaeridium complex (White 1842). Upper Cretaceous, England.

Emended diagnosis. Shape: The body is spherical to subspherical in shape with only minor dorso-ventral flattening.

Wall: The cyst wall is apparently two-layered, the two layers being closely appressed except where the periphragm alone forms the processes. The surface is smooth to coarsely verrucate; an internal structuring maybe present. The processes are generally smooth.

Paratabulation: The parasutures are occasionally defined either by a positive (i.e. ridges) or a negative (i.e. lack of granulation) ornamentation. The paratabulation formula is $4^{\prime}, 6^{\prime \prime}, 6 \mathrm{c}, 6^{\prime \prime \prime}, 1 \mathrm{p}, 1^{\prime \prime \prime}{ }^{\prime \prime}, 5 \mathrm{~s}$.

Processes: The plate-centred processes are basically of tubiform shape and flare distally to terminate with several spines. They vary in width according to position on the cyst with the pre-, postcingular and antapical processes being the largest. Rearly a solid process is present in the $1^{\prime \prime \prime}$ position and one may be present in the parasulcal region. The process formula is $4^{\prime}, 6^{\prime \prime}, 5-6^{\prime \prime \prime}, 1 \mathrm{ps}, 1 \mathrm{p}, 1^{\prime \prime \prime \prime}$ plus $0-1 \mathrm{~s}$.

Paracingular processes are absent; the only parasulcal process normally present is the posterior parasulcal.

Archaeopyle: An apical archaeopyle is normally developed by the detachment of the apical paraplates as a unit (Type $\overline{\mathrm{A}}$ ). It has a strongly zigzag margin with a deep parasulcal notch.

Remarks. The diagnosis has been emended mainly to give the paratabulation formula, to indicate process variation, to allow the presence of certain solid processes and to correct the process formula.

The genera Cymososphaeridium gen. nov. and Stiphrosphaeridium gen. nov. have similar process formulae but the processes are basically solid not tubiform. The process formula of the tubiform processes in Perisseiasphaeridium is the same as in Oligosphaeridium but fine, solid paracingular and parasulcal processes are also present. 
Oligosphaeridium asterigerum (Gocht) Davey and Williams 1969.

Pl. 1, fig. 12

1959: Hystrichosphaeridium asterigerum Gocht, p. 67, pl. 3, fig. 1; pl. 7, figs. $1-4$.

1969: Oligosphaeridium asterigerum (Gocht) Davey and Williams, p. 5.

Remarks. The holotype of $O$. asterigerum (Gocht, pl. 3 , fig. 1) comes from a borehole in northwest Germany and is reported to be of early Hauterivian age. Gocht differentiates his new species from $O$. complex (White) Davey and Williams $1966 \mathrm{~b}$ mainly by the form of the processes which are considered to be narrower and not to widen into funnels. However, from his illustrations of these two species $(O$. asterigerum, pl. 7, fig. 4; O. complex, pl. 7, fig. 5) there does not appear to be a significant difference in process form, as he admits in the text (p. 68). I consider that there is a complete graduation between these process types, not only between individuals but upon an individual depending on the position of the process. However, the holotype of $O$. asterigerum does have a narrow, apparently solid, process (upper right of specimen) and this has been found consistently during the present study; its position is $1^{\prime \prime \prime}$. Thus the occurrence of this process indicates that a more precise way of differentiating the two species is by their process formulae:-

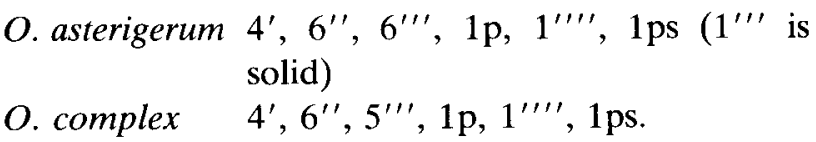

Occurrence. $O$. asterigerum at Speeton has a known range of early Valanginian (bed D4) to latest early Hauterivian (bed C7F) and in the Haldager, No. 1 borehole has a basal occurrence in core $2647^{\prime}-57^{\prime}$.

$O$. complex only occurred rarely in the youngest two cores of the Haldager No. 1 borehole and in the Speeton section has an apparent basal occurrence in bed $\mathrm{C} 4 \mathrm{C}$ of late Hauterivian age.

\section{Oligosphaeridium diluculum sp. nov.}

\section{Pl. 2, figs. 1-5}

Derivation of name. Latin, diluculum, daybreak or dawn - this species being one of the earliest members of this genus in the Lower Cretaceous.

Diagnosis. Shape: The body is subspherical.

Wall: The thin wall is apparently two-layered. The periphragm is smooth and alone forms the processes.

Paratabulation: None.

Processes: The plate - centred processes vary con- siderably in size and shape with the larger ones occupying the pre- and postcingular and antapical regions. The processes terminate distally with aculeate and secate spines which maybe branched. Minor fenestration maybe present. One side of the larger processes is often partly lost and in the narrower processes, particularly $1{ }^{\prime \prime}, 1 \mathrm{p}$ and the parasulcal process(es), it may be completely lost and these then appear to be solid. The process formula is $4^{\prime}, 6^{\prime \prime}, 6^{\prime \prime \prime}, 1 \mathrm{p}, 1^{\prime \prime \prime \prime}, 1 \mathrm{ps}$ plus 0-1s.

Archaeopyle: An apical archaeopyle (Type $\bar{A}$ ) is typically developed.

Holotype. MPK 2609, slide SAL 4638/III, Haldager No. 1 borehole, core depth $2866^{\prime}-76^{\prime}$, Denmark. Ryazanian, Early Cretaceous.

\section{Dimensions}

Body diameter

$\begin{array}{cc}\text { Holotype } & \text { Range } \\ (\mu \mathrm{m}) & (\mu \mathrm{m})\end{array}$

(excluding processes)

length

(archaeopyle developed) $48 \quad 46(48) 50$

$\begin{array}{lll}\text { width } & 56 & 42(48) 56\end{array}$

Process length 24-36 18-36

Description. The cyst wall is relatively thin (less than $1 \mu \mathrm{m})$ and consequently it is often distorted. The processes vary from approximately 1 to $6 \mu \mathrm{m}$ in stem width with the pre- and postcingular and antapical processes being the largest. The walls of these processes sometimes appear to be fibrous and this may be related to incipient fenestration which is usually best developed, when present, at the bases of the processes. When the process stem is short, the rather irregular distal furcations may extend to the body surface.

Remarks. $O$. diluculum sp. nov. is characterised by its deeply and irregularly furcate, basically tubiform processes. It is thought to be related to Stiphrosphaeridium arbustum sp. nov. which differs by having strongly fenestrate processes that terminate with distal trabeculae. Oligosphaeridium pulcherrimum (Deflandre and Cookson 1955) Davey and Williams 1966 b may be distinguished by its more regularly tubiform processes, 18 in number, whick are strongly fenestrate distally.

Occurrence. $O$. diluculum is moderately common at depths $2832^{\prime}-42^{\prime}$ to $2896^{\prime}-2915^{\prime}$ in the Haldager No. 1 borehole but in eastern England only occurs, with certainty, in the stenomphalus Zone, late 
Ryazanian. It was also recovered from bed D7G at Speeton which probably belongs to the same zone.

Oligosphaeridium sp. I

Pl. 2, figs. 6-8

Description. The cyst is subspherical in shape and is composed of a thin, smooth to scabrate wall. The basically tubiform processes are short, broad and are usually finely fenestrate. They may have short stems (pl. 2, fig. 6) and then flare widely to give a broad funnel or the stem may be absent and flaring or funneling commences directly from the endocyst (pl. 2, fig. 7). In the latter case they simulate annulate complexes, particularly when the fenestration is coarse and irregular so that the process wall begins to disintegrate (pl. 2, fig. 8). The process formula appears to be $4^{\prime}, 6^{\prime \prime}, 5^{\prime \prime \prime}, 1 \mathrm{ps}, 1 \mathrm{p}, 1^{\prime \prime \prime \prime}$.

Remarks. Oligosphaeridium sp. 1 appears most similar to Amphorula metaelliptica Dodekova 1969, described from the Tithonian of Bulgaria, which differs by having arcuate processes and significantly both paracingular and parasulcal processes.

Occurrence. Oligosphaeridium sp. I is a rare but distinctive form which, as yet, has only been found in eastern England, in the runctoni Zone (early Ryazanian) and in bed $\mathrm{E}$ at Speeton. Distortion of the rare specimens observed makes measurements rather meaningless.

Genus Surculosphaeridium Davey, Downie, Sarjeant and Williams 1966 emend.

Type species. Surculosphaeridium cribrotubiferum (Sarjeant 1960) Davey et al. 1966. Upper Jurassic (Lower Oxfordian), England.

Emended Diagnosis. Shape: The body is spherical to subspherical in shape with only minor dorso-ventral flattening.

Wall: The cyst wall is apparently two-layered, the two layers being closely appressed except where the periphragm alone forms the processes. The surface is smooth to lightly ornamented and the processes are generally smooth.

Paratabulation: Parasutures not observed.

Processes: The processes are solid, often with internal vacuoles, and simply to complexly branched. The apical, pre-, postcingular, parasulcal and antapical processes are plate-centred. Although the paracingular processes are usually deeply bifurcate and also plate-centred, sometimes the bifurcation extends to the cyst wall so forming two processes per cingular paraplate. The processes vary in width according to position on the cyst with the pre-, postcingular and antapical being the largest. The process formula is $4^{\prime}$, $6^{\prime \prime}, 6 \mathrm{c}, 6^{\prime \prime}, 1 \mathrm{p}, 1^{\prime \prime \prime \prime}, 1-5 \mathrm{~s}$.

Archaeopyle: An apical archaeopyle is normally developed by the detachment of the apical paraplates as a unit (Type $\overline{\mathrm{A}}$ ). It has a strongly zigzag margin with a deep parasulcal notch.

Remarks. The diagnosis has been emended principally to correct the process formula and to limit the genus to species having only one process per paraplate in the apical, pre-, postcingular and antapical series. For the latter reason Surculosphaeridium vestitum (Deflandre) is transferred to Systematophora on p. 14.

\section{Surculosphaeridium sp. I}

Pl. 3, figs. 7, 10

Description. The cyst is subspherical in shape and composed of a thin, more or less smooth wall. The processes are solid, often with internal vacuoles (particularly the larger processes), and are of variable shape; their distribution conform with the process formula for the genus. The larger processes - the pre-, postcingular and antapical - are relatively broad proximally, sometimes with arcuate bases, sometimes bifurcate medially and typically widen distally into a broad, fenestrate fan which distally may be slightly denticulate. The paracingular processes are narrow, deeply furcate and bifid distally; the parasulcal processes are similarly narrow and briefly bifurcate distally. An apical archaeopyle is typically developed.

Dimensions. Cyst diameter (excluding processes) $38-53 \mu \mathrm{m}$; process length $10-25 \mu \mathrm{m}$.

Occurrence. This species was only found in one sample, core $2647^{\prime}-57^{\prime}$, Haldager No. 1 borehole, where it was relatively common. Undistorted specimens are rare.

Surculosphaeridium sp. II

Pl. 4, figs. 1, 2

Discription. The cyst is subspherical in shape and composed of a thin, more or less smooth wall. The stout, solid processes are strongly vacuolate, vary somewhat in size depending on their position and indicate the process formula $4^{\prime}, 6^{\prime \prime}, 6 \mathrm{c}, 6^{\prime \prime}, 4-5 \mathrm{c}, 1 \mathrm{p}$, 
$1^{\prime \prime \prime \prime}$. The larger processes, belonging to the pre-, postcingular and antapical series, are unbranched but recurve distally to form a membranous, subcircular flange orientated parallel to the cyst wall. The paracingular processes are moderately to deeply furcate and terminate distally with a small pad or are briefly bifurcate. The narrow parasulcal processes are rather irregularly branched. An apical archaeopyle is typically developed.

Dimensions. Cyst diameter (excluding processes) $32-50 \mu \mathrm{m}$; process length $14-22 \mu \mathrm{m}$, process width up to $2 \mu \mathrm{m}$.

Remarks. This rare but distinctive species is undoubtedly best assigned to Surculosphaeridium even though the major process are unusual, in that they are not branched.

Occurrence. As yet this species has only been found in beds D4 and D3 of the early Valanginian at Speeton, northeast England.

\section{Surculosphaeridium sp. III}

Pl. 4, figs. 3-6

Description. The cyst is subspherical in shape and composed of a smooth wall of moderate thickness. The stout, solid processes are often strongly vacuolate and appear to be distributed according to the generic process formula. The pre-, postcingular and antapical processes divide initially either medially or distally into two to several branches which may then subdivide further. When the branching is restricted distally a radiating secate margin may develop. The larger processes may be arcuate proximally. The paracingular processes occur in pairs that may be joined by a small proximal ridge. Both the paracingular and parasulcal processes are briefly bifurcate distally. An apical archaeopyle is typically developed.

Remarks. Except for the presence of paracingular processes, this species is very similar to Cymososphaeridium sp. I. All the specimens encountered have been damaged and so meaningful measurements have not been possible.

Occurrence. As yet Surculosphaeridium sp. III has only been found in beds D4 and D3 of the early Valanginian at Speeton, northeast England.

Genus Stiphrosphaeridium gen. nov.

Type species. Stiphrosphaeridium dictyophorum
(Cookson \& Eisenack, 1958) comb. nov. Upper Jurassic, Papua.

Derivation of name. Greek, stiphros, solid or stout with reference to the strong, solid processes.

Diagnosis. Shape: The body is spherical to subspherical in shape with only minor dorso-ventral flattening.

Wall: The cyst wall is apparently two-layered, the two layers being closely appressed except where the periphragm alone forms the processes. The surface is smooth to scabrate.

Paratabulation: Parasutures not observed.

Processes: The plate-centred processes are solid and fenestrate. Paracingular processes are absent. The pre-, postcingular $\left(2-6^{\prime \prime \prime}\right)$ and antapical processes are the largest but do vary in size depending on their position on the cyst. The processes may be solid for most of their length before becoming fenestrate, or the fenestrations may extend down to the body surface. Distally these larger processes each terminate in a more or less complete circular trabeculum; in the smaller process $\left(1-4^{\prime}, 1 \mathrm{ps}, 1 \mathrm{p}\right)$ the trabeculae are sometimes incompletely developed. The process formula is $4^{\prime}, 6^{\prime \prime}, 6^{\prime \prime \prime}, 1 \mathrm{p}, 1^{\prime \prime \prime \prime}, 1 \mathrm{ps}$, plus $0-4 \mathrm{~s}$.

Archaeopyle: An apical archaeopyle is developed by the apical paraplates as a unit (Type $\bar{A}$ ). The archaeopyle has a strongly zigzag margin.

Remarks. An alternative way of defining most of the processes is to describe them as fenestrate funnels which may become solid proximally. Stiphrosphaeridium gen. nov. is considered to be most closely related to Systematophora and differs principally by never having paracingular processes. Processes occupying the major plate series (i.e. pre-, postcingular and antapical) of Systematophora are never solid, one per paraplate, but always form annulate complexes which proximally typically extend over a large proportion of a paraplate. It is possible to interpret the larger processes of Stiphrosphaeridium, when they are fenestrate down to the cyst wall, as representing narrow or reduced annulate complexes. The processes of Oligosphaeridium are similarly distributed on the cyst surface but are tubiform.

Stiphrosphaeridium dictyophorum (Cookson \& Eisenack) comb. nov.

Pl. 2, figs. $10-13$

1958: Hystrichosphaeridium dictyophorum Cookson and Eisenack, p. 44 , pl. 11, fig. 14

1969: Oligosphaeridium dictyophorum (Cookson and Eisenack) Davey and Williams, p. 5. 
1979: Polystephanephorus sarjeantii Gitmez, Davey, p. 65, pl. 3, figs. 4,5 .

Description. S. dictyophorum comb. nov. illustrates all the characteristics of the genus. Most of the major processes are solid proximally for up to half their length and only in the largest processes, mainly the dorsal postcingular and the antapical, do the fenestrations extend to the body surface. Thus, in the latter cases, it could be interpreted that the 2 to 4 processes arising from the surface constitute narrow or restricted annulate process complexes. Parasulcal processes, additional to the posterior parasulcal, are rare as is the first postcingular process (1"'). The trabeculae are smooth to slightly denticulate distally. An apical archaeopyle is usually developed.

Remarks. S. dictyophorum is very similar to $S$. anthophorum (Cookson \& Eisenack 1958) comb. nov. which appears to have broader and more fenestrate processes. The holotype of $S$. anthophorum (Cookson \& Eisenack 1958, pl. 11, fig. 12) is reported as occurring in the Apto-Albian of Papua; the other specimen illustrated as this species by Cookson \& Eisenack in the same paper (pl. 11, fig. 13) is reported as occurring in sample 27 (I.E.C. well 1) from the Upper Jurassic of Papua, as does the holotype of $S$. dictyophorum. This specimen, attributed to $S$. anthophorum, has more solid (less fenestrate) processes than the holotype of $S$. anthophorum and more closely resembles the holotype of $S$. dictyophorum; it should probably be re-assigned to this latter species.

Specimens previously assigned to Polystephanephorus sarjeantii by Davey (1979) are here re-assigned to $S$. dictyophorum. P. sarjeantii is similar to $S$. anthophorum although if paracingular processes are present then this species belongs to Hystrichosphaerina Alberti 1961 and closely resembles $H$. orbifera (Klement) Stover \& Evitt 1978.

Occurrence. S. dictyophorum only occurs in one sample $\left(2935^{\prime}-45^{\prime}\right)$ in the Haldager No. 1 borehole and it is there very common. It is similarly very common in the two ammonite zones of the early Ryazanian, eastern England (runctoni and kochi Zones). Its reported occurrence by Davey 1979 in the oppressus Zone of the Portlandian of eastern England is now considered probably due to contamination.

\section{Stiphrosphaeridium arbustum sp. nov.}

Pl. 3, figs. 1-4

Derivation of name. Latin, arbutus, with trees - with reference to the tree - like form of the processes.

Diagnosis. Shape: The body is subspherical in shape.

Wall: The two layers of the cyst wall are closely appressed except where the periphragm forms the processes. The surface is almost smooth.

Processes: The plate-centred processes vary considerably in size, particularly in width, with the smallest being 1"', $1 \mathrm{p}$ and the parasulcal process(es). The larger processes are poorly to complexly fenestrate; distally each terminates with an incompletely developed circular trabeculum which is slightly spinous distally. Where trabeculae are not developed the processes are distally irregularly aculeate and secate. The more proximal parts of the incompletely fenestrate processes are solid, hollow with a restricted lumen or very rarely hollow. Internal vacuoles are often present. The process formula is $4^{\prime}, 6^{\prime \prime}, 6^{\prime \prime \prime}$, $1^{\prime \prime \prime \prime}, 1 \mathrm{ps}$, plus $0-1 \mathrm{~s}$.

Archaeopyle: An apical archaeopyle (Type $\overline{\mathrm{A}}$ ) is typically developed.

Holotype. MPK 2610, slide SAL 4639/III, Haldager No. 1 borehole, core depth 2896'-2915', Denmark. Ryazanian, Early Cretaceous.

\section{Dimensions}

$$
\begin{gathered}
\text { Body diameter } \\
\text { length } \\
\text { (archaeopyle } \\
\text { developed) } \\
\text { width }
\end{gathered}
$$

Process length

Description. The cyst wall is relatively thin (less than $1 \mu \mathrm{m})$ and because of this is easily distorted and broken. The processes vary from approximately 1 to $7 \mu \mathrm{m}$ in stem width with the pre-, postcingular and antapical processes being the widest. In some of these latter processes the fenestration continues to the body surface so giving rise to what could be termed "narrow-based annulate complexes". Usually, however, fenestration commences medially to distally and the more proximal parts of the processes are solid. Occasionally the internal vacuoles in the processes appear to have joined so giving a hollow process. Rarely this is well developed and the lumen of the stem appears to be confluent with the distal fenestrate funnel of the process so giving a "tubiform" process. Typically the stem walls of these processes are fenestrate.

Remarks. S. arbustum sp. nov. is characterised by 
possessing strongly fenestrate processes which terminate distally by incompletely developed trabeculae. The processes are very variable and the above features do not occur on all the processes. This species is intermediate between Oligosphaeridium diluculum sp. nov., which has basically tubiform processes that are not strongly fenestrate and never have distal trabeculae, and Stiphrosphaeridium dictyophorum in which practically all the processes are strongly fenestrate with circular, distal trabeculae.

Occurrence. $S$. arbustum is relatively common in core $2896^{\prime}-2915^{\prime}$, Haldager No. 1 borehole, and infrequently in the icenii and stenomphalus Zones of eastern England.

\section{Other species}

The following species is here transferred to Stiphrosphaeridium.

Stiphrosphaeridium anthophorum (Cookson and Eisenack) Davey comb. nov. = Hystrichosphaeridium anthophorum Cookson and Eisenack 1958, p. 43, pl. 11, fig. 12. Lower Cretaceous (Apto - Albian), Australia.

Genus Cymososphaeridium gen. nov.

Type species. Cymososphaeridium validum sp. nov. Early Cretaceous, Hauterivian, Denmark.

Derivation af name. Latin, cymosus, full of shoots with reference to the branching nature of the processes.

Diagnosis Shape: The body is spherical to subspherical in shape with minor dorso-ventral flattening.

Wall: The cyst wall is apparently two-layered, the two layers being closely appressed except where the periphragm alone forms the processes. The surface is smooth to scabrate.

Paratabulation: Parasutures not observed.

Processes: The solid, plate-centred processes vary in size with $1^{\prime \prime \prime}$ being particularly small. Paracingular processes are absent. The processes branch, usually medially or distally, to give rise to two to four main branches and these may give rise to further branches. The process formula is $4^{\prime}, 6^{\prime \prime}, 6^{\prime \prime \prime}, 1 \mathrm{p}, 1^{\prime \prime \prime \prime}, 1 \mathrm{ps}$.

Archaeopyle: An apical archaeopyle is developed by the detachment of the apical paraplates as a unit (Type $\bar{A}$ ). The archaeopyle has a strongly zigzag margin.
Remarks. The form of the processes in Cymososphaeridium gen. nov. is practically identical to that of Surculosphaeridium Davey et al. 1966 but the latter genus can easily be distinguished by the presence of paracingular processes. The process formula of $C y$ mososphaeridium is the same as for Oligoshaeridium and Stiphrosphaeridium gen. nov.; the former genus, however, has tubiform processes whereas the processes in the latter genus are strongly fenestrate.

Cymososphaeridium validum sp. nov.

Pl. 3, figs. 5, 6, 8, 11

Derivation of name. Latin, validus, strong and powerful - with reference to the stout processes.

Diagnosis. Shape: The body is spherical to subspherical.

Wall: The two wall layers are closely appressed except where the periphragm forms the processes. The surface is more or less smooth.

Processes: The plate-centred process vary somewhat in size with $1^{\prime \prime \prime}$ being particularly narrow and flimsy. They are smooth and solid, except sometimes for internal vacuoles. The processes are parallel sided before branching to initially give two to four branches which then branch further. The initial branching is typically medial to distal although in the postcingular processes it is proximal. The process formula is $4^{\prime}, 6^{\prime \prime}, 6^{\prime \prime \prime}, 1 \mathrm{p}, 1^{\prime \prime \prime \prime}, 1 \mathrm{ps}$.

Archaeopyle: An apical archaeopyle (Type $\bar{A}$ ) is typically developed.

Holotype. MPK 2611, slide SAL 4628/I, Haldager No. 1 borehole, core depth $2505^{\prime}-25^{\prime}$, Denmark. Hauterivian, Early Cretaceous.

\section{Dimensions}

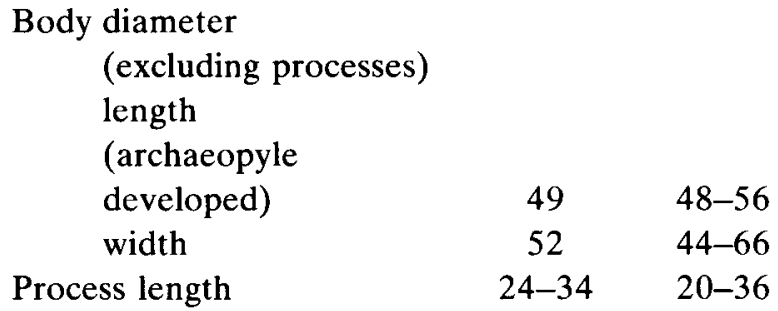

Description. The wall is thin, less than $1 \mu \mathrm{m}$ in thickness, and the cyst is often distorted. The narrow process $1 " \prime$ is approximately $1 \mu \mathrm{m}$ thick and the other processes are between 2 and $6 \mu \mathrm{m}$ in thickness. The internal vacuoles are not abundant and are often noticeably concentrated at the bases of the processes. 
Remarks. The presence of solid branching processes and the lack of paracingular processes distinguishes C. validum $\mathrm{sp}$. nov. from all previously described species. It may be identical to specimens wrongly attributed to Hystrichosphaeridium ramuliferum by Gocht 1959 (pl. 3, fig. 9) from the Valanginian and Hauterivian of Germany.

Occurrence. It occurs moderately commonly in cores $2505^{\prime}-25^{\prime}$ and $2545^{\prime}-65^{\prime}$ in the Haldager No. 1 borehole and in the Hauterivian of the North Sea Basin.

\section{Cymososphaeridium sp. I}

Pl. 3, figs. 9, 12

Description. The cyst is of subspherical shape and is composed of a moderately thick wall from which arise 19 solid, stout processes. They are strongly vacuolate. They occasionally branch medially but typically they divide distally to give several short branches which bear spines; the branches are sometimes broad, being spinous distally, and resemble the "pseudo-trabeculae" of Systematophora sp. I. Process 1 "' is noticeably narrower than the other processes. The larger processes, mainly the postcingular, may be arcuate proximally.

Remarks. Cymososphaeridium sp. I differs from $C$. validum principally by the lack of complexly branched processes. It appears to be most similar to a form described herein as Surculosphaeridium sp. II which has very similar major processes but also has paired paracingular processes.

Occurrence. Cymosophaeridium sp. I occurs consistently in beds D3 and D2 (early Valanginian) at Speeton, northeastern England.

Genus Perisseiasphaeridium Davey and Williams 1966b

Remarks. The presence of both tubiform and solid processes differentiates Perisseiasphaeridium from all described genera except Callaiosphaeridium Davey and Williams 1966b which, however, has hollow paracingular processes and an epicystal archaeopyle. Perisseiasphaeridium is morphologically intermediate between Oligosphaeridium, which has the same arrangement of tubiform processes, and Systematophora, which has comparable paracingular and parasulcal processes.
Perisseiasphaeridium insolitum sp. nov.

Pl. 4, figs. 8-10

Derivation of name. Latin, insolitus, unusual or uncommon - with reference to the unusual occurrence of both hollow and solid processes in this species.

Diagnosis. Shape: The body is subspherical in shape.

Wall: The two wall layers are closely appressed except where the periphragm forms the processes. The surface is more or less smooth.

Processes: The plate-centred, tubiform processes are arranged $4^{\prime}, 6^{\prime \prime}, 5^{\prime \prime \prime}, 1 \mathrm{p}, 1^{\prime \prime \prime \prime}, 1 \mathrm{ps}$; they flare distally to give rise to several aculeate spines. There are six pairs of solid, paracingular processes and up to four additional parasulcal processes; these processes typically bifurcate distally. The $1^{\prime \prime}$ process, when present, is of the latter type.

Archaeopyle: An apical archaeopyle (Type $\bar{A}$ ) is typically developed.

Holotype. MPK 2612, slide SAL 5254/2, bed 1 (Casey 1973), Spilsby Sandstone, Portlandian (giganteus or anguiformis/kerberus/okusensis Zones). Nettleton Top Barn Pit, Lincolnshire, eastern England.

\section{Dimensions}

Body diameter

(excluding processes)

Tubiform process

stem length

$\begin{array}{cc}\text { Holotype } & \text { Range } \\ (\mu \mathrm{m}) & (\mu \mathrm{m})\end{array}$

$44 \times 58 \quad 40-62$

$18-28 \quad 14-28$

Description. The cyst wall is thin, being under $1 \mu \mathrm{m}$ in thickness, and is consequently often distorted and/or broken. The solid and tubiform processes are of comparable length and approximately equal to half the body diameter. The tubiform processes are sometimes faintly striate along their lengths and proximally adjacent to the cyst body; the stem width varies from 3 to $6 \mu \mathrm{m}$. The solid processes measure less than $2 \mu \mathrm{m}$ in thickness. The paracingular region appears usually to possess aligned, low, ovoidal ridges (pl. 4, fig. 9), one per paraplate, with each process of the paracingular pair arising from one end of the ridge.

Remarks. Although $P$. insolitum sp. nov, is often distorted or broken, the combination of tubiform and solid processes is very distinctive and differentiates it from all previously described species except $P$. pan- 
nosum Davey and Williams 1966b. The latter species has irregularly branched and fenestrate tubiform processes in contrast to the simple tubiform processes of $P$. insolitum.

Occurrence. In the Haldager No. 1 borehole, $P$. insolitum is moderately common in core $2969^{\prime}-89^{\prime}$ and infrequent in core $2989^{\prime}-3009^{\prime}$, cores that are dated as early Portlandian to early Ryazanian. In eastern England, it is common in the oppressus Zone and infrequent in the giganteus Zone (anguiformis okusensis Zones).

\section{Genus Hystrichosphaerina Alberti 1961}

Remarks. The suggested synonymy of Polystephanephorus Sarjeant, 1961b and Hystrichosphaerina by Duxbury, 1980, is herein rejected. The type species of the former genus, $P$. calathus (Sarjeant, 1961a) Downie and Sarjeant, 1965, possesses trabeculae linking the annulate complexes and this feature is considered to be of generic importance. Hystrichosphaerina never has linking trabeculae.

Hystrichosphaerina, however, is considered to be much more closely related to Stiphrosphaeridium gen. nov. which possesses solid and annulate complexes in the pre- and postcingular regions but no paracingular processes. Hystrichosphaerina has similar annulate complexes which are rarely, if ever, solid and, generally, well defined paracingular processes. These thin long solid processes were noted in the original diagnosis by Alberti, 1961, who considered them probably equatorial in position. Examples of these processes can plainly be seen on $H$. schindewolfii Alberti, 1961, illustrated as Perisseiasphaeridium eisenacki by Davey, 1974 (pl. 6, fig. 5) from the late Barremian. The paracingular processes number 1 or 2 per paraplate and bifurcate once or twice distally. The paracingular processes illustrated on a specimen of $H$. schindewolfii by Duxbury, 1980 (pl. 6, fig. 6; text-fig. 10) are very poorly developed being none, 1 or 2 per paraplate. In slightly younger sediments, in the Apto-Albian, a comparable species occurs which completely lacks paracingular processes and is assignable to Stiphrosphaeridium anthophorum (Cookson \& Eisenack, 1958) comb. nov. Identical specimens are illustrated by Davey, 1979c, (pl. 7, figs. 1, 4, 9) from the Apto-Albian of northwest Europe as Polystephanephorus anthophorum.

\section{Hystrichosphaerina schindewolfii Alberti, 1961}

1961: Hystrichosphaerina schindewolfii Alberti, pp. 38, 39, pl. 10, figs. $1-3,6,7$.
1965: Systematophora schindewolfi (Alberti) Downie \& Sarjeant, p. 146

1969: Perisseiasphaeridium eisenacki Davey \& Williams, p. 6

1980: Hystrichosphaerina schindewolfii Alberti, Duxbury, p. 126, pl. 6 , fig. 6

Remarks. See above, under generic "Remarks".

\section{The Broomea complex}

Remarks. Recently there has been considerable discussion regarding this lineage (Wiggins 1975, Brideaux 1975) and, in particular, the type of archaeopyle present (Dörhöfer, Duxbury and Eaton pers. comm.). The procedure adopted here regarding the archaeopyle is that it is either formed by the removal of the apical paraplates or one to three anterior intercalary paraplates. The latter are so called simply because they located beneath the apical horn and above the precingular paraplates - no direct relationship between these anterior intercalary paraplates and those present in peridinacean species is implied.

This lineage contains mainly elongate forms with an apical and two antapical horns and an anterior intercalary or apical archaeopyle. The generic distinctions are summarised below:-

Broomea Cookson and Eisenack, 1958 emend. Lentin and Williams 1976. One elongate, hexagonal intercalary paraplate (2a) is lost from the mid-dorsal epicystal surface during archaeopyle formation.

Batioladinium Brideaux, 1975. The archaeopyle is apical; it has a deep parasulcal notch and the breakage is high on the dorsal epicystal surface above the intercalary paraplates which remain in place. Necrobroomea Wiggins, 1975 is accepted as being a junior synonym of Batioladinium.

Imbatodinium Vozzhennikova, 1967. At the present time I reject Wiggins, 1975 synonymisation of Imbatodinium and Pareodinia for two reasons. Firstly, the type species I. kondratjevii has the unusual morphology of an indented paracingulum and a noticeable parasulcus. Secondly, and perhaps of even greater importance, is that there is still considerable confusion as to whether the archaeopyle is apical or intercalary.

Gochteodinia Norris, 1978. This genus contains forms with a 2 - paraplate intercalary archaeopyle and a spinose ornament.

Pareodinia Deflandre, $1947 \mathrm{c}$ emend. Wiggins 1975. This genus is restricted to forms with a $2-3$ paraplate intercalary archaeopyle, low non-spinose ornament and no distinctive antapical horn. A kalyptra may be present. (My interpretation of Pare- 
odinia differs from that of Stover and Evitt only in that spinose forms are considered to belong to Gochteodinia).

Aprobolocysta Duxbury, 1977 emend. Duxbury, 1980. This genus is here restricted to include forms that apparently possess walls of two layers, the periphragm being distinctly membranous, with or without minor antapical projections, and an apical archaeopyle with deep parasulcal notch.

Kalyptea Cookson and Eosenack, 1960b emend. Wiggins 1975 has a 1 to 3 paraplate intercalary archaeopyle but has only single horns at the apex and antapex.

Cantulodinium Alberti 1961 is pear-shaped, has a 2-3 paraplate intercalary archaeopyle and 3 or more hollow hypocystal horns.

\section{Genus Batioladinium Brideaux 1975 \\ Batioladinium longicornutum (Alberti) Brideaux 1975}

1961: Broomea longicornuta Alberti, p. 27, pl. 5, figs. 18-21; pl. 6, figs. 1-2

1975: Batioladinium longicornutum (Alberti) Brideaux, p. 1240

Occurrence. At Speeton B. longicornutum has a recorded occurrence of early Hauterivian, bed C11, (Davey, 1974) to earliest late Barremian, basal Upper B beds, Duxbury 1980. In Haldager No. 1, it occurs at $2505^{\prime}-25^{\prime}$ and $2545^{\prime}-65^{\prime}$.

Batioladinium pomum sp. nov.

Pl. 5, figs. 2-4

Derivation of name. Latin, pomum, fruit of any kind - with reference to the characteristic shape of this species.

Diagnosis. Shape: Basically elongate - ovoidal with some dorso-ventral flattening; broadest in the paracingular region. Apical horn moderately long, slender, gradually tapering and arising relatively abruptly from the main part of the cyst. Typically two low, rounded antapical horns.

Wall: Apparently autophragm only.

Paratabulation: Paracingulum sometimes indicated by alignment of granules. Other paratabulation absent.

Ornament: Increases in coarseness from apical to antapical region. Pitting and low granules are typical of the apical region; the granulation becomes more pronounced towards the paracingulum and particularly on the hypocyst. Irregular spinules and small tubercles may be present here.
Archaeopyle: Apical with deep parasulcal notch; operculum usually remains attached.

Holotype. MPK 2613, slide SAL 4640/I, Haldager No. 1 borehole, core depth 2935'-45', Denmark. Ryazanian, Early Cretaceous.

$\begin{array}{lcc}\text { Dimensions } & \begin{array}{c}\text { Holotype } \\ (\mu \mathrm{m})\end{array} & \begin{array}{c}\text { Range } \\ (\mu \mathrm{m})\end{array} \\ \text { Cyst length } & 94 & 83(88) 94 \\ \text { Cyst width } & 40 & 33(37) 40\end{array}$

Description. The length of the apical horn is typically $1 / 4$ to $1 / 3$ of the overall cyst length.

Remarks. B. pomum sp. nov. is distinguished from $B$. jaegeri (Alberti) Brideaux, 1975 by its shorter apical horn, rounded antapical horns and its distinctively variable granulate ornament. B. micropodum (Eisenack and Cookson) Brideaux, 1975 is distinguished by its very short apical horn and densely granulate thick wall.

Occurrence. B. pomum occurs in the early Valanginian to Ryazanian in cores $2832^{\prime}-42^{\prime}$ to $2935^{\prime}-45^{\prime}$, Haldager No. 1 borehole and only in the lamplughi Zone of Eastern England.

Batioladinium radiculatum $\mathrm{sp}$. nov.

PI. 5, figs. 1, 7-9

Derivation of name. Latin, radicula, small root - with reference to the form of the antapical horns.

Diagnosis. Shape: Basically elongate, dorso-ventrally flattened; broadest in the paracingular region. Apical horn long, gradually tapering and proximally merges with the main part of the cyst body; distal part is solid with internal vacuoles. Two relatively short antapical horns are present; they taper rapidly distally and are strongly vacuolate throughout. They may give rise to irregular branches or may be bifurcate.

Wall: Apparently autophragm only.

Paratabulation: Paracingulum may be defined by aligned granules.

Ornament: Epicyst mainly smooth to lightly punctate. Granules and tubercles gradually start to appear towards or in the paracingular region and become more abundant on the hypocyst.

Archaeopyle: Apical with deep parasulcal notch.

Holotype. MPK 2614, slide SAL 4640/I, Haldager 
No. 1 borehole, core depth $2935^{\prime}-45^{\prime}$, Denmark. Ryazanian, Early Cretaceous.

\section{Dimensions}

Cyst length

(not incl. antapical

horns)

Cyst length (not incl. antapi-

cal horns; archaeopyle

developed)

Antapical horns

$$
38 \text { and } 49 \quad 23-49
$$

Remarks. B. radiculatum sp. nov. is differentiated from the rather similar species $B$. longicornutum by its generally weaker and shorter antapical horns and by its ornamented hypocyst. In addition, $B$. radiculatum appears to become extinct within the late Ryazanian whereas $B$. longicornutum does not have its basal occurrence until much higher in the sequence, in the early Hauterivian.

Occurrence. $B$. radiculatum occurs in the Ryazanian of Haldager No. 1 borehole, in cores $2866^{\prime}-76^{\prime}$ and $2935^{\prime}-45^{\prime}$, and in the runctoni to icenii Zones of eastern England.

Batioladinium varigranosum (Duxbury) comb. nov. Pl. 5, figs. 5, 6

1977: Aprobolocysta varigranosa Duxbury, p. 53, pl. 14, figs. 6, 7; fig. 20

Remarks. Numerous examples of this interesting species have been examined in the Valanginian and Hauterivian of eastern England and in the Haldager No. 1 borehole. The cyst wall is relatively thick and densely granular with additional verrucae and irregular spinules usually more concentrated towards the antapex. This distribution of ornament is a common feature of the genus Batioladinium. Antapical horns, if developed at all, are small and rounded; an apical horn is absent. Complete specimens are relatively rare so the latter characteristic is normally impossible to determine. Very similar forms exist that do have a short apical horn (placed in B. cf. varigranosum, see below) which cannot be differentiated from $B$. varigranosum if the archaeopyle is completely developed. The evidence available suggests that the two forms are closely related and probably intergrade. Hence, because of the apical archaeopyle, the type of ornament and the intergrading with forms having an apical horn and antapical horns (therefore definitely belonging to Batioladinium), the present species is here transferred from Aprobolocysta to Batioladinium.

Occurrence. B, varigranosum occurs from the early Valanginian (bed D4, Speeton) to the basal Hauterivian (bed D2, Speeton, Duxbury 1977). It occurs in cores $2505^{\prime}-25^{\prime}$ to $2647^{\prime}-57^{\prime}$, Haldager No. 1 borehole of Hauterivian to Valanginian age.

Batioladinium cf. varigranosum (Duxbury 1977) comb. nov.

Pl. 5, fig. 10

Remarks. This form is identical to $B$. varigranosum in size and type of ornamentation (see above). However, a low apical horn is present. The two forms are clearly related and as $B$. cf. varigranosum is the stratigraphically older it is quite possible that $B$. varigranosum is derived from it.

Occurrence. $B$. cf. varigranosum occurs in the Ryazanian cores $2866^{\prime}-76^{\prime}$ to $2935^{\prime}-45^{\prime}$, Haldager No. 1 borehole and in the runctoni, icenii and stenomphalus Zones of eastern England.

\section{Batioladinium sp. I}

Pl. 5, figs. 11-13

Description. This is an elongate species with overall length greater than twice the width. The apical horn is relatively short and merges into the main part of the cyst; the antapical horns are low and rounded. The wall is thickish and may be densely granular and pitted. The ornament becomes stronger towards the antapex, becoming coarsely granular with irregular spinules. The latter may also be granular and sometimes are particularly well developed on the antapical horns. The archaeopyle is apical. A paracingulum may be defined by ornament alignment.

Dimensions. Range - overall length $78 \mu \mathrm{m}$ (one specimen), length (archaeopyle developed) $57-72 \mu \mathrm{m}$, width $30-38 \mu \mathrm{m}$.

Remarks. The most similar species in overall appearance is Imbatodinium krondratjevii Vozzhennikova, 1967 which appears to possess only isolated tubercles.

Occurrence. This species occurs only in the lamplughi, runctoni, and kochi Zones of eastern England. 
Genus Gochteodinia Norris, 1978

Gochteodinia villosa (Vozzhennikova) Norris, 1978

Pl. 6, figs. 1, 4-6

1967: Imbatodinium villosum, p. 56 , pl. 12 , figs. $1-3$; pl. 13, figs. 1-3; pl. 14, figs. 1, 2; pl. 15, figs. $1,2$.

1975: Pareodinia dasyforma Wiggins, p. 107

1978: Gochteodinia villosa (Vozzhennikuva) Norris, p. 7

Remarks. G. villosa, as accepted here, is extremely variable in overall size, and length and density of process cover. A paracingulum (pl. 6, fig. 6) is occasionally discernible. The holotype (Vozzhennikova, pl. 12, fig. 3a) has a more or less even cover of relatively short, acuminate or slightly bifid processes. This type (pl. 6, fig. 6) is prevalent in the earlier part of the species range but higher in the sequence the larger and longer processed forms (pl. 6, fig. 1) are dominant. The earliest forms of this lineage (pl. 6, fig. 5), in the giganteus Zone of eastern England, have very short, blunted processes. An interesting variant are specimens which have ball-like distal process terminations (pl. 6, fig. 4); these are particularly common in the kochi Zone of eastern England. An archaeopyle is typically developed and, although the breakage often appears to be somewhat irregular, probably two anterior intercalary paraplates (2 I) are involved.

Occurrence. G. villosa occurs in the giganteus to albidum Zones of eastern England. It is rare in the giganteus Zone, approximately $4 \%$ in the oppressus Zone, $0.5 \%$ in the runctoni Zone, $14 \%$ in the kochi Zone, $9.5 \%$ in the icenii Zone, $4.5 \%$ in the stenomphalus Zone and very rare in the albidum Zone. It is very rare in the giganteus Zone of Dorset, southern England. G. villosa, therefore has a peak abundance in the mid Ryazanian.

Gochteodinia villosa subsp. multifurcata nov.

Pl. 6, fig. 13

1977: Pareodinia dasyforma Wiggins, Duxbury, p. 56, pl. 14, fig. 3

1978: P. dasyforma Wiggins, Duxbury, pl. 1, fig. 2

1978: Gochteodinia villosa (Vozzhennikova) Norris, pl. 11, fig. 10

Derivation of name. Latin, multus, much; furcatus, forked - with reference to the presence of distally furcate processes.

Diagnosis. A subspecies of $G$. villosa possessing one to many processes which flare distally to give three to several small spines.
Type. MPK 2616, slide “Upper D4"/1', bed D4, Speeton Clay, early Valanginian, Speeton, Yorkshire, eastern England.

$\begin{array}{lcc}\text { Dimensions } & \begin{array}{c}\text { Type } \\ (\mu \mathrm{m})\end{array} & \begin{array}{c}\text { Range } \\ (\mu \mathrm{m})\end{array} \\ \text { Body length } & 70 & 56-79 \\ \text { Body width } & 32 & 24-36 \\ \text { Process length } & 7-10 & 5-12\end{array}$

Remarks. G. villosa, at present, is accepted as being a rather variable species (see above) and can bear processes which briefly bifurcate distally. However, if three or more distal spines occur then the specimen is attributable to $G$. villosa subsp. multifurcata nov. It is distinguished from $G$. judilentinae McIntyre \& Brideaux, 1980 , by having many more processes.

Occurrence. This subspecies is considered to have evolved from G. villosa at or near the Valanginian Ryazanian boundary. It occurs in the early Valanginian (Duxbury, 1978; personal observation); in the Canadian Valanginian (McIntyre \& Brideaux, 1980); and probably into the early Hauterivian (as Pareodinia dasyforma in Duxbury, 1977). This subspecies only occurs at $2647^{\prime}-77^{\prime}$ (Valanginian) and $2832^{\prime}-42^{\prime}$ (early Valanginian - late Ryazanian) in the Haldager No. 1 borehole.

Gochteodinia virgula sp. nov.

Pl. 6, figs. 2, 3, 7, 8, 10, 11

Derivation of name. Latin, virga, twig or branch with reference to the irregularly branched nature of the processes.

Diagnosis. Shape: Ovoidal to elongate-ovoidal with minor dorso-ventral ventral flattening. Apical horn small and rounded, antapical horns absent.

Wall: Apparently two-layered with the layers being closely appressed except where the periphragm alone forms the processes. The wall is thick and densely intraperforate so having a spongy appearance. The processes are smooth.

Paratabulation: The paracingulum and parasulcus are sometimes discernible by a lack of processes.

Processes: Basically short but of variable length and are typically branched (terminating distally in a small or large bifurcation) or, more rarely, are simple.

Archaeopyle: Large and appears to be formed by the displacement of 2-3 anterior intercalary paraplates (2-3I). 
Holotype. MPK 2615, slide SAL 5014/2, bed 3 (Casey 1973), Spilsby Sandstone, Portlandian (primitivus Zone). Nettleton Top Barn Pit, Lincolnshire, eastern England.

$\begin{array}{lcc}\text { Dimensions } & \begin{array}{c}\text { Holotype } \\ (\mu \mathrm{m})\end{array} & \begin{array}{c}\text { Range } \\ (\mu \mathrm{m})\end{array} \\ \text { Body length } & 56 & 54-60 \\ \text { Body width } & 38 & 30-44 \\ \text { Process length } & 6-12 & 6-18\end{array}$

Description. The distinctive, relatively thick wall is approximately $2 \mu \mathrm{m}$ thick.

Remarks. G. virgula sp. nov. is distinguished from $G$. villosa by its thicker, intraperforate wall and the consistent presence of short bifurcating processes.

Occurrence. This is a rare species in the oppressus and lamplughi Zones of eastern England and in core $2989^{\prime}-3009^{\prime}$, Haldager No. 1 borehole.

Gochteodinia mutabilis (Riley) comb. nov.

Pl. 6, figs. 9, 12

1980: Pareodinia mutabilis Riley, p. 324, pl. 3, figs. 6, 10

Remarks. Because of the presence of a spinose ornament, this species is here re-attributed to Gochteodinia Norris, 1978.

Occurrence. This rare but distinctive species has a top known stratigraphic range in the albani Zone of the earliest Portlandian of southern England. It occurs rarely at $3150^{\prime}-60^{\prime}$ and $3180^{\prime}-90^{\prime}$ (early Portlandian) of the Haldager No. 1 borehole. The specimens recorded in the "giganteus" Zone of eastern England (pl. 6, figs. 9, 12) are, at the present, considered to have been reworked.

\section{Gochteodinia sp. I}

Pl. 6, figs. 14,15

Description. This form is closely related to G. virgula and differs in that firstly, the apical horn is more or less absent and secondly, that the processes are longer and more complex; they tend to be linked distally by trabeculae.

Occurrence. Gochteodinia sp. I occurs rarely in cores $2969^{\prime}-2989^{\prime}$ and $2989^{\prime}-3009^{\prime}$ (early Ryazanian Portlandian), Haldager No. 1 borehole.
Gochteodinia sp. II

Pl. 7, figs. 1-4

Description. This form has an elongate-ovoidal shape with a moderate length apical horn which is rounded distally. The wall is scabrate. The ornament consists of peritabular ridges and low crests which give rise to somewhat fibrous processes of varying length and width; these usually bifurcate distally. The pre-, postcingular and cingular paraplate series are clearly present although it is impossible to determine accurately the number in each.

Occurrence. Gochteodinia sp. II is rare in the giganteus Zone (anguiformis - okusensis Zones) of eastern England.

Genus Pareodinia Deflandre, 1947c

Pareodinia sp. I

Pl. 4, figs. $12-14$

Description The cyst shape is elongate to ovoidal with an apical horn of moderate length arising abruptly from the main body of the cyst. The wall is of moderate thickness and is smooth but densely intraperforate giving a spongy appearance. Vestiges of a kalyptra are sometimes present. The archaeopyle appears to be formed by three intercalary paraplates (3I) although they usually remain in position.

Remarks Pareodinia sp. I superficially resembles $P$. groenlandica Sarjeant, 1972, which differs by having a stronger, subconical apical horn and a strongly reticulate surface pattern.

Occurrence. It is rare to infrequent in cores $2647^{\prime}-2657^{\prime}, 2832^{\prime}-2842^{\prime}$ and $2866^{\prime}-2876^{\prime}$, Haldager No. 1 borehole.

Genus Aprobolocysta Duxbury, 1977, emend Duxbury, 1980.

Remarks. See the introduction to this section (p. 22).

Aprobolocysta neistosa Duxbury, 1980

Pl. 7, figs. 5-7

1980: Aprobolocysta neistosa Duxbury, p. 112, pl. 2, figs. 8, 9.

Remarks. The present specimens are very similar to those described by Duxbury, 1980, except that they are smaller and have lower crests. The length of the cyst body (archaeopyle developed and without 
crests) is $47-59 \mu \mathrm{m}$, width (without crests) is $30-33 \mu \mathrm{m}$ and the height of the crests is up to $8 \mu \mathrm{m}$.

Occurrence. Duxbury, 1980, records $A$. neistosa from the early (including mid) and basal late Barremian at Speeton, England. In the present study this species occurs only in bed D3 (early Valanginian) at Speeton and spasmodically in the Haldager No. 1 borehole

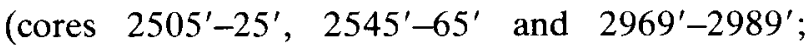
Hauterivian - early Ryazanian/late Portlandian).

Genus Cantulodinium Alberti, 1961

Cantulodinium speciosum Alberti, 1961

Pl. 4, fig. 11

1961: Cantulodinium speciosum Alberti, p. 23, pl. 3, figs. 20-23; pl. 12 , fig. 3

Remarks. The present specimen agrees very closely with those described by Alberti, 1961. In addition, it may be added, that the epicyst is more or less smooth whereas the hypocyst bears an irregular scatter of tubercles. The archaeopyle is wide, has a more or less smooth precingular margin and is apparently formed by the loss of two anterior intercalary paraplates ( 2 I).

Occurrence. C. speciosum has previously been reported from the Valanginian of Germany by Alberti 1961, and from the Upper Jurassic of Denmark by Stover and Evitt (1978). Single specimens occur only in cores $2545^{\prime}-65^{\prime}$ and $2896^{\prime}-2915^{\prime}$ of the Haldager No. 1 borehole. (The reported Upper Jurassic occurrence from Denmark may be incorrect and due to wrongly dated borehole material).

\section{Other taxa}

Genus Aldorfia Stover \& Evitt, 1978

Aldorfia sp. A

Pl. 7, figs. $13-15$

Description. This is a moderately large, subspherical to rhomboidal form having a hollow, conical apical horn formed only of periphragm. The paracingulum may also be marked by a slight extension of the periphragm; the parasulcus is defined by a weak depression. The endophragm and periphragm are separated by a distinct pericoel which is traversed by isolated collumellae which sometimes coalesce to form short muri. A precingular archaeopyle ( $\left.3^{\prime \prime}\right)$ is typically developed.

Dimensions. Overall length 77 (89) $103 \mu \mathrm{m}$, overall width 57 (70) $80 \mu \mathrm{m}$.
Remarks. Aldorfia sp. A is similar to A. aldorfensis (Gocht) Stover \& Evitt 1978 from the Bajocian Bathonian. The latter differs by not having a true apical horn and by having generally longer columellae which are particularly well developed at the cyst apices. A. spongiosa McIntyre \& Brideaux 1980 comb. nov., of Portlandian - Ryazanian (-?Valanginian) age has broad, sponge-like thickenings linking the periphragm and endophragm

Occurrence. Aldorfia sp. A is relatively common in the anguiformis - kerberus Zones (formerly giganteus Zone) of Lincolnshire, England, where it occurs with A. spongiosa.

\section{Other Species}

The following two species are here attributed to the genus Aldorfia on the basis of their wall structure and general form:

Aldorfia dictyota (Cookson \& Eisenack, 1960b) comb. nov. $=$ Scriniodinium dictyotum Cookson \& Eisenack, 1960b, p. 248-9, pl. 37, figs. 8, 9.

Aldorfia spongiosa (McIntyre \& Brideaux, 1980) comb. nov. = Apteodinium spongiosum McIntyre \& Brideaux, p. 12, pl. 2, figs. 8-12

Genus Apteodinium Eisenack, 1958

Apteodinium sp. A

Pl. 7, figs. 11, 12, 16

Description. This, moderately large, subspherical species is characterised by a thick, intraperforate or spongy wall which can measure up to $7 \mu \mathrm{m}$ in thickness. The wall surface is smooth. A short apical horn is present. The paracingulum is typically well defined by parallel ridges which are particularly noticeable at the cyst margins. The parasulcus is marked by a shallow, elongate indentation.

Dimensions. Overall length $72-103 \mu \mathrm{m}$, overall width 56-76 $\mu \mathrm{m}$, maximum wall thickness $4-7 \mu \mathrm{m}$.

Occurrence. Apteodinium sp. A is common in the kerberus Zone (early Portlandian) of Dorset (7\%) and the kochi Zone (early Ryazanian) of Norfolk $(8 \%)$. It is rare in the oppressus to runctoni Zones (early Ryazanian - early Portlandian) of eastern England and in cores 2866'-76', 2896'-2915', $2969^{\prime}-89^{\prime}$ and $2989^{\prime}-3009^{\prime}$, Haldager No. 1 borehole. The age of these cores is late Ryazanian to late early Portlandian which is, at the present, this forms longest range. 
Genus Avellodinium Duxbury, 1978

The following species is here attributed to the genus Avellodinium on the basis of its process type and distribution, the presence of an epicystal archaeopyle and its general form.

Avellodinium culmulum (Norris, 1965) comb. nov. $=$ Gonyaulax culmula Norris, p. 793-5, figs. 1, 2, 6-9.

Genus Canningia Cookson \& Eisenack 1960b

Canningia compta sp. nov.

Pl. 8, figs. 3-6

Derivation of name. Latin, comptus, ornamented with reference to the nature of the cyst surface.

Diagnosis. Shape: Cysts subspherical to slightly angular with some dorso-ventral flattening. Apical region broadly conical; antapex rounded to slightly indented. Widest portion of the cyst is in the paracingular region.

Wall/Ornament: Wall of moderate thickness. Lightly pitted to foveolate and verrucate. Ornament less pronounced towards the centre of the dorsal postcingular paraplate and in the parasulcal region.

Paratabulation: Absent to poorly defined by relatively stronger ornamentation along the boundaries of the paracingulum on the dorsal surface and towards the margins of the dorsal postcingular paraplate. Parasulcus often defined by a distinct groove which extends across the ventral surface from the antapex towards the parasulcal notch and terminating in the paracingular region.

Archaeopyle: Apical; parasulcal notch strongly indented and offset to the left of the mid-line. Margin is strongly zig-zag.

Holotype. MPK 2617, slide SAL 5011/1, Sandringham Sands, Brook Farm, North Runcton, Norfolk, England. Lamplughi Zone, Portlandian.

\section{Dimensions}

Pericyst length

$\begin{array}{cc}\begin{array}{c}\text { Holotype } \\ (\mu \mathrm{m})\end{array} & \begin{array}{c}\text { Range } \\ (\mu \mathrm{m})\end{array} \\ & 68-82\end{array}$

Pericyst length

(archaeopyle developed) $\quad 54 \quad 54$ (59) 65

$\begin{array}{lll}\text { Pericyst width } & 52 & 52(61)\end{array}$

Description The wall is approximately 1 to $1.5 \mu \mathrm{m}$ in thickness (including ornament). The ornament is most easily observed in plan view and appears to consist of well developed verrucae. When the ornament is high it is noticeable at the lateral margins of the cyst but when low the cyst margins appear to be almost smooth. In the latter case it is probable that a foveolate wall structure is present.

Remarks. The type of ornament, together with the strongly zig-zag archaeopyle margin with the deep parasulcal notch distinguishes $C$. compta sp. nov. from other members of this genus.

Occurrence. C. compta occurs only rarely in the kerberus (formerly giganteus) Zone of Dorset and eastern England. However, it occurs abundantly in eastern England from the oppressus to stenomphalus Zone and typically makes up between 20 and $40 \%$ of the dinocyst assemblage; its greatest recorded abundance is in a sample from the primitivus Zone where it attains $74 \%$. Undoubtedly, this species flourished in the relatively shallow shelfal seas established over eastern England during the Portlandian and the Ryazanian for it does not occur in the same abundance over most of the North Sea Basin. C. compta is rare in the albidum Zone and has only very rarely been recorded from the basal Valanginian.

In Haldager No. 1 borehole C. compta is moderately to very common in cores $2866^{\prime}-76^{\prime}$ to $2989^{\prime}-3009^{\prime}$ (late Ryazanian to early Portlandian) and rarer at $2772^{\prime}-82^{\prime}, 2832^{\prime}-42^{\prime}, 3080^{\prime}-3100^{\prime}$ and $3180^{\prime}-90^{\prime}$. Thus the overall range here, as onshore, is early Valanginian to early Portlandian.

\section{Genus Cannosphaeropsis O. Wetzel 1933}

Cannosphaeropsis thula sp. nov.

Pl. 8, figs. 7-11

1977: Adnatosphaeridium apiculatum (Cookson and Eisenack) Lentin and Williams; Duxbury, pl. 10, fig. 1

1979: Cannosphaeropsis sp. A Davey, p. 56, pl. 1, figs. 6, 9, 12

Derivation of name. Latin, thule, furthest north with reference to its boreal occurrence.

Diagnosis. Shape: The pericyst, excluding processes, is ovoidal to oviform with very little dorso-ventral flattening.

Wall: The cyst wall is apparently two-layered, the two layers being closely appressed except where the periphragm alone forms the processes. The wall is of moderate thickness and the surface is smooth to lightly pitted.

Paratabulation: Parasutures are occasionally visible along the paracingulum and, more rarely, surrounding the parasulcal region.

Processes: These are parasutural in position. The gonal processes are trifurcate distally whereas the parasutural processes bifurcate distally. The furca- 
tions join with neighbouring ones to form a trabeculum which reflects the paratabulation. Distally the trabeculum bears small spines. The processes are longest on the dorsal hypocyst and decrease in size away from this region, being lowest on the ventral epicyst.

Archaeopyle: Precingular, Type P (3" only), with free operculum.

Holotype. MPK 2618, slide SAL 5260/4, Sandringham Sands, cut off channel, West Abbey, Norfolk, England. Kochi Zone, Ryazanian.

\section{Dimensions}

(excluding processes)

$\begin{array}{lcc}\text { length } & 56 & 48(56) 68 \\ \text { width } & 39 & 38(42) 48 \\ \text { um height of trabecula } & 18 & 14-28\end{array}$

Maximum height of trabecula $18 \quad 14-28$

Description. The number of parasutural processes tends to increase in the lower Portlandian to upper Kimmeridgian and are often free distally. In these forms the trabeculum tends to become more irregular.

Remarks. C. thula sp. nov. is distinguished from previously described species of this genus by the relatively large size of the cyst body compared with the overall cyst size and also by the much greater height of the processes on the dorsal hypocyst than on the ventral epicyst. $C$. thula appears to be the only member of this genus represented at this stratigraphic level in northwest Europe.

Occurrence. The total range of $C$. thula, deduced from onshore English sections, appears to be from the Zone of Epipallaceras sp. (uppermost Kimmeridgian) to the icenii Zone (late Ryazanian). However it is only consistently present, and relatively common (1-5\%), from the kerberus (giganteus) to the kochii Zones. In the Haldager No. 1 borehole it has a topmost occurrence in core $2935^{\prime}-45^{\prime}$ but only becomes relatively common in cores $2969^{\prime}-89^{\prime}$ and $2989^{\prime}-3009^{\prime}$. It also occurs at $3150^{\prime}-60^{\prime}$ and $3180^{\prime}-90^{\prime}$.

Genus Chlamydophorella Cookson and Eisenack 1958

Chlamydophorella membranoidea Vozzhennikova 1967

Pl. 8, fig. 12
1967: Chlamydophorella mambranoidea Vozzhennikova, p. 114, pl. 48 , figs. $1-10$

1979: Chlamydophorella sp. A Davey, p. 56, pl. 3, figs. 10-13

Remarks. The density and regularity of the processes and the amount of parasutural alignment they exhibit appears to be rather variable in $C$. membranoidea, a species described from the Upper Jurassic of the USSR. Of note in some of the present specimens and in the type material is the occasional presence of a rudimentary corona of the Stephanelytron - type. This was not described by Vozzhennikova but is clearly illustrated by her holotype (pl. 48, fig. 9b) and by other specimens ( $\mathrm{pl} .48$, figs. 5, 10). As in Stephanelytron the corona does not occupy the antapex but is situated on the antapical paraplate which is displaced onto the ventral surface. S. scarburghense Sarjeant 1961 is similar but has a much more strongly developed corona which is always present. C. membranoidea, however, does indicate that there is a complete gradation from Stephanelytron to Chlamydophorella.

Occurrence. Specimens assignable to C. membranoidea probably range from the basal Kimmeridgian to the late Hauterivian. The reduced corona, however, has not been observed below the kerberus (giganteus) Zone in Dorset or below the core $2989^{\prime}-3009^{\prime}$, Haldager No. 1 borehole. Forms with a corona occur rather spasmodically in the Ryazanian and Valanginian of eastern England but are relatively common in the Hauterivian.

Genus Cribroperidinium Neale and Sarjeant 1962 Cribroperidinium sp. A

Pl. 10, figs. 5, 6

Description. This is a large ovoidal species of Cribroperidinium composed of a thick, densely intraperforate wall and possessing a long apical horn. The latter is hollow for approximately half its length. The paratabulation is moderately well defined by low ridges which bear small to large spines. The latter are particularly well developed at the base of the apical horn, along the paracingular margins and around the antapical paraplate where they are sometimes complexly linked. A large precingular (Type P) $3^{\prime \prime}$ only archaeopyle is usually developed.

Remarks. In gross morphology Cribroperidinium sp. A is similar to Gonyaulacysta longicornis (Downie) Sarjeant, 1969 especially because of the length of the apical horn. G. longicornis is differentiated from Cribroperidinium sp. A by being more spherical in shape, being thinner walled, having a very poor 
paratabulation and almost completely lacking spines. In the Upper Kimmeridgian, Portlandian and Ryazanian less destinctive forms than Cribroperidinium sp. A occur which have shorter apical horns and are less spinose. In this study these forms are assigned to Cribroperidinium spp.

Occurrence. Cribroperidinium sp. A is very common in the anguiformis - okusensis (giganteus), oppressus and primitivus Zones of eastern England and may represent up to $46 \%$ of the dinocyst assemblage. It is common in only one core sample $\left(2989^{\prime}-3009^{\prime}\right.$, early Portlandian) in Haldager No. 1 borehole and is present rarely at $2896^{\prime}-2915^{\prime}$ and $3080^{\prime}-100^{\prime}$.

Genus Dichadogonyaulax Sarjeant 1966b Dichadogonyaulax pannea (Norris) Sarjeant 1969 Pl. 9, fig. 10

1965: Leptodinium panneum Norris, p. 796, figs. 3, 10-13 1969: Dichadogonyaulax pannea (Norris) Sarjeant, p. 14

Occurrence. D. pannea is a consistently occurring species from the giganteus Zone of Dorset, where it can attain up to $7 \%$ of the dinocyst assemblage, to the pectinatus Zone of the Kimmeridgian. Below this zone it has been recorded infrequently down to the mutabilis Zone of the Kimmeridgian. It occurs in samples $3080^{\prime}-3100^{\prime}$ to $3180^{\prime}-3190^{\prime}$, Haldager No. 1 borehole, and is most common in the deepest sample.

Genus Egmontodinium Gitmez \& Sarjeant, 1972 Egmontodinium expiratum sp. nov.

Pl. 8, figs. 13-16

1979: Egmontodinium sp. A, Davey p. 61, pl. 1, figs. 7, 10

Derivation of name. Latin, expiratus, to cease - with reference to the disappearance of the paratabulation in this species.

Diagnosis. Shape: Cysts ovoidal to elongate with rounded apices. Dorso-ventral flattening is only minor.

Wall: The wall is apparently two-layered and of moderate thickness; it is smooth to scabrate. The crests and processes are smooth.

Paratabulation: This is only partly defined by low parasutural crests and appears to be $4^{\prime}, 6^{\prime \prime}, 6^{\prime \prime \prime}, 1 \mathrm{p}$, $1^{\prime \prime \prime \prime}$. The crests are basically penitabular although the precingular crests may be parasutural at or towards the paracingular region and diverge from here towards the apices. The limits of the parasulcus may be also, partly defined, as may the paraplates 1 "' and $1 \mathrm{p}$.
Penitabular crests define the position of the antapical paraplate $\left(1^{\prime \prime \prime \prime}\right)$. The boundaries of the paracingulum are practically absent.

Processes: These are located on the crests and, although are of variable width, they are usually broadly membranous. Distally the gonal processes are briefly trifurcate and the parasutural processes briefly bifurcate. Rarely isolated processes are present in parasutural or penitabular positions, particularly in the paracingular region.

Archaeopyle: Apical; margin strongly zig-zag with a deep parasulcal notch. The archaeopyle breakage occurs midway between the penitabular crests of the apical and precingular series.

Holotype. MPK 1264, slide GB 424/2, Bed J (Arkell 1933), Cherty series, Tilly Whim Caves, Dorset, England. Portlandian, kerberus Zone.

\section{Dimensions}

Cyst length

$$
\begin{array}{ccc}
\text { Holotype } & \text { Range } & \text { Single } \\
(\mu \mathrm{m}) & (\mu \mathrm{m}) & (\mu \mathrm{m})
\end{array}
$$

Cyst length (archaeopyle developed) $\quad 64 \quad 50(61) 70$

Cyst width

$40 \quad 40(44) 52$

Maximum height of processes

$10 \quad 8-13$

Description. The crests are sometimes striate or vacuolate and vary in height from simple ridges to membranous crests. The majority of the processes are extensions of the crests and are linked by the crests. The crests are usually best developed and most noticeable in the antapical region. Often in the parasulcal and apical regions it is difficult to determine whether or not the crests are parasutural or penitabular. The apical region is rarely seen because it is detached in archaeopyle formation.

Remarks. E. expiratum sp. nov. is intermediate between E. polyplacophorum Gitmez and Sarjeant, 1972, and E. torynum (Cookson and Eisenack) Davey 1979. The former lacks processes entirely whereas the latter has many parasutural processes but lacks crests and a paratabulation.

Occurrence. E. expiratum is a rare species occurring from the anguiformis - okusensis (giganteus) to the runctoni Zones (basal Ryazanian) of eastern England and only in the kerberus (giganteus) Zone of Dorset. In the Haldager No. 1 borehole it occurs at $2667^{\prime}-77^{\prime}, 2896^{\prime}-915^{\prime}, 2969^{\prime}-89^{\prime}$ and $3080^{\prime}-100^{\prime}$. 
It is possible that the younger two occurrences could be due to reworking.

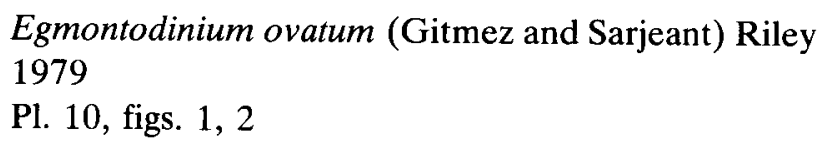

1970: Systematophora sp. Gitmez, p. 296 , pl. 8 , fig. 5

1972: Systematophora ovata Gitmez and Sarjeant, p. 237, pl. 14, figs. 2,3

1979: Egmontodinium ovatum (Gitmez and Sarjeant) Riley, p. 221

Description. The cyst is elongate to ovoidal, thin walled and bears a moderate number of short processes. The processes are membranous and distally bifurcate to give two relatively thin, often flexuous, recurved spines. These may terminate in brief bifurcations. The processes appear to be sutural and are aligned along the precingular, postcingular and paracingular boundaries. The membranous part of each process extends along the paraplate boundaries although sutural crests or ridges do not appear to be present. The archaeopyle is apical.

Remarks. The holotype of $E$. ovatum has been reexamined and has identical processes to those figured here. The elongate shape of the cyst and the shape and distribution of the processes is very similar to that found in E. torynum (Cookson and Eisenack) Davey 1979 and the two species are considered to be closely related.

Occurrence. Rare in the hudlestoni Zone to the top of the Zone of Epipallasceras sp. (Kimmeridgian) in Dorset; rare in the pectinatus Zone (Kimmeridgian) of Yorkshire. The holotype is described from the baylei Zone (basal Kimmeridgian) of Cambridgeshire, England; its position at this stratigraphic level is anomalous since this is considerably lower than its known stratigraphic range. E. ovatum did not occur in the Haldager No. 1 borehole.

\section{Genus Gonyaulacysta Deflandre 1964 \\ Gonyaulacystra sp. A \\ Pl. 10, fig. 3}

1979: Gonyaulacysta sp. A Davey, p. 61, pl. 4, fig. 6

Remarks. The specimens attributed to this species from the Haldager No. 1 well are extremely similar in overall form to the originally described material from eastern England.
Occurrence. Previous to this study Gonyaulacysta sp. A had only been recorded from two localities (Norfolk and Yorkshire) in eastern England and extremely rarely in the North Sea Basin. In the Haldager No. 1 borehole it occurs relatively infrequently in cores $2866^{\prime}-76^{\prime}$ to $2935^{\prime}-45^{\prime}$ (late Ryazanian ?early Ryazanian).

\section{Gonyaulacysta sp. B}

Description. The present species is very similar to Gonyaulacysta sp. A Davey 1979 but possesses intratabular and parasutural spines that may be complexly linked.

Occurrence. This form was only noted in the Haldager No. 1 borehole in cores $2772^{\prime}-82^{\prime}$ and $2832^{\prime}-42^{\prime}$ (early Valanginian - late Ryazanian).

Genus Hystrichogonyaulax Sarjeant 1969

Hystrichogonyaulax cf. cladophora (Deflandre, 1938b) Stover and Evitt, 1978

P1. 10, fig. 7

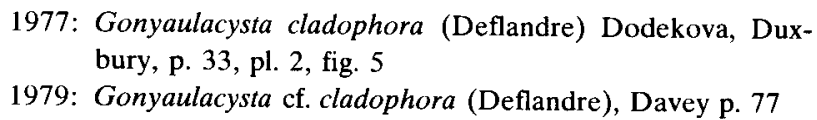

Occurrence. This large species, which is superficially similar to $G$. cladophora, has a known Hauterivian to late Valanginian range although its peak abundance is in the early Hauterivian. In the Haldager No. 1 borehole it is common at $2505^{\prime}-25^{\prime}$ and rare at $2545^{\prime}-65^{\prime}$.

Genus Kleithriasphaeridium Davey 1974

Kleithriasphaeridium porosispinum sp. nov. Pl. 10, figs. 8-12

1979: Kleithriasphaeridium sp. A Davey, p. 61, pl. II, figs. 10, 11

Derivation of name. Latin, poros, porous; spina, thorn - with reference to the perforate appearance of the processes.

Diagnosis. Shape: The body is of ovoidal shape with only minor dorsoventral flattening.

Wall: The wall is apparently two-layered and of moderate thickness. The periphragm is extremely fibrous and alone forms the processes. Fibres radiate from the bases of the processes over the body and the surface region between processes may be fibrous or strongly to weakly reticulate.

Processes: These are tubiform and terminate with 
a smooth, or slightly to strongly serrate margin. Rarely they bifurcate medially or distally. Usually two of the apical processes are linked by a crest. The width and length of the processes vary according to their position on the cyst; the largest are dorsal hypocystal and antapical in position and the smallest are the parasulcals. The apical and paracingular processes are intermediate in size. The process formula appears to be $1 \mathrm{pr}, 4^{\prime}, 6^{\prime \prime}, 6 \mathrm{c}, 5^{\prime \prime \prime}, 1 \mathrm{p}, 1^{\prime \prime \prime \prime}$ plus xs. Fewer processes sometimes occur apparently resulting from a reduction in the number of processes in and around the parasulcal region.

Archaeopyle: Precingular, Type P ( $3^{\prime \prime}$ only) with free operculum.

Holotype. MPK 2620, slide GB 424/2, Bed J (Arkell 1933, Cherty Series, Tilly Whim Caves, Dorset, England. Portlandian, kerberus Zone.

$\begin{array}{lcc}\begin{array}{l}\text { Dimensions } \\ \text { Holotype } \\ (\mu \mathrm{m})\end{array} & \begin{array}{c}\text { Range } \\ (\mu \mathrm{m})\end{array} \\ \begin{array}{l}\text { Pericyst diameter } \\ \text { (excluding processes) }\end{array} & 40 \times 48 & 32(44) 57 \\ \begin{array}{l}\text { Length of processes } \\ \text { Maximum length of } \\ \text { processes }\end{array} & 11-20 & 10-24 \\ & 20 & 16(21) 26\end{array}$

Remarks. K. porosispinum sp. nov. is characterised, and distinguished from other members of the genus Kleithriasphaeridium, by the presence of highly fibrous processes. There appears to be a difference in the degree of ornamentation between the onshore English specimens and those recovered from Denmark. Whereas the surface of the cyst is strongly fibro-reticulate on the English specimens, the Danish specimens tend to be smooth to slightly reticulate.

Occurrence. This species is common $(5 \%)$ in the kerberus ("giganteus") Zone of Dorset and has been reported down to the pectinatus Zone (late Kimmeridgian). In eastern England it has a definite range of stenomphalus Zone (late Ryazanian) to the anguiformis - okusensis (formerly giganteus) Zones. It has been reported from the latest Ryazanian and early Valanginian here but these rare occurrences may be due to reworking. In the Haldager No. 1 borehole it occurs from $2866^{\prime}-76^{\prime}$ (late Ryazanian) to the base of the examined section.

Genus Muderongia Cookson and Eisenack 1958 Muderongia sp. A

Pl. 9, figs. 1-3

1979: Muderongia sp. A Davey, p. 64, pl. 2, figs. 4, 5
Occurrence. Muderongia sp. A is a rare to relatively common species from the giganteus Zone to the pallesioides Zone (Riley 1974) in Dorset, England. It is a relatively common species from $3080^{\prime}-3100^{\prime}$ to $3180^{\prime}-90^{\prime}$ in the Haldager No. 1 borehole.

Muderongia simplex Alberti, 1961, subsp. microperforata subsp. nov.

Pl. 9, figs. 4-6

Diagnosis. A subspecies of $M$. simplex possessing a perforate periphragm. The perforations are numerous, small and are circular to subpolygonal in outline.

Type. MPK 2619, slide SAL 4637/III, Haldager No. 1 borehole, core depth $2832^{\prime}-42^{\prime}$, Denmark. Early Valanginian - late Ryazanian, Early Cretaceous.

\section{Dimensions}

Overall length

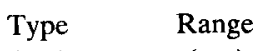

Overall width

$(\mu \mathrm{m})$

$$
(\mu \mathrm{m})
$$

$85 \quad 78-85$

Overall length

(archaeopyle developed)

$51-70$

$42-60$

Description $M$. simplex subsp. microperforata closely resembles $M$. simplex in all respects except for the very characteristic perforation of the periphragm. The perforations are often better developed, and more easily observed, on the horns. Typically an apical horn, two lateral and two antapical horns are present although the lateral horns and one of the antapical horns may be reduced to bulges. A clear paracingulum is usually present and extends along the lateral horns to give a lateral indentation to them. The inner body is rounded in shape and may be slightly asymmetric antapically.

Occurrence. This subspecies only occurs in one core, $2832^{\prime}-42^{\prime}$, in the Haldager No. 1 borehole (early Valanginian to late Ryazanian) and it is here abundant. It has also been observed, albeit rarely, in coeval sediments in the North Sea Basin.

\section{Muderongia sp. B}

Remarks. This form is similar to $M$. simplex subsp. microperforata except that the perforations are confined to the distal portions of the horns.

Occurrence. Muderongia sp. B occurs rarely in core $2545^{\prime}-65^{\prime}$ (probable early Hauterivian) and also in the North Sea Basin in Hauterivian - Valanginian sediments. 
Genus Occisucysta Gitmez 1970

Occisucysta sp. A

Pl. 10, figs. 14, 15

1977: Occisucysta evitti (Dodekova) Gitmez; Duxbury, p. 43, pl. 3 , figs. 1,5

1979: Occisucysta sp. A Davey, p. 64, pl. 3, figs. 7, 8 (figured as Uccisucysta cf. evittii)

Occurrence. Davey (1979) published the range of this species as late Ryazanian (albidum Zone) to early Valanginian. It has also been recovered from the stenomphalus Zone of eastern England thus extending its known range. In the Haldager No. 1 borehole, it is found rarely in core $2822^{\prime}-32^{\prime}$ to core $2935^{\prime}-45^{\prime}$ (early Valanginian - Ryazanian). The specimen in core $2545^{\prime}-65^{\prime}$ (Hauterivian) is considered to have been reworked.

Genus Polygonifera Habib, 1972

Polygonifera staffinensis (Gitmez, 1970) comb. nov.

1970: Meiourogonyaulax staffinensis Gitmez, p. 276-8, pl. 3, fig. 1

1972: Meiourogonyaulax staffinensis Gitmez, Gitmez \& Sarjeant, p. $224-5$, pl. 9 , fig. 4

1972: Hexagonifera jurassica Gitmez \& Sarjeant, p. 240-1, pl. 14, figs. 5,8

1976: Lithodinia staffinensis (Gitmez) Gocht, p. 334

Remarks. P. staffinensis comb. nov. is basically a cavate dinocyst, with or without incipient antapical horn development, having weak to moderate paratabulation and a large, apical archaeopyle. It is recognised as being a rather variable morphotype especially with respect to the amount of cavation developed. However, being cavate this species does not belong in Lithodinia, nor can it be attributed to Hexagonifera which possesses an intercalary archaeopyle. In most respects this species closely resembles the Jurassic species Polygonifera evittii Habib 1972 and for this reason staffinensis is transferred to this genus.

Occurrence. P. staffinensis occurs consistently, and is often common ( $10 \%$ albani Zone of Dorset) from the albani Zone to the elegans Zone of the Kimmeridgian in Dorset. Spasmodic occurrences above this range, in the Portlandian and Ryazanian are considered to be probably due to reworking. Similarly, it has also been recorded very rarely below this range down to the pseudocordata Zone of the late Oxfordian. P. staffinensis was only recorded from the two basal samples analysed in the Haldager No. 1 borehole.
Genus Pterospermella Eisenack, 1972

Pterospermella sp. A

Description. The present forms are closely comparable to Pterospermella aureolata (Cookson \& Eisenack, 1958) except that there is a distinctive, thickened outer border to the flange.

Occurrence. Pterospermella sp. A is restricted to cores $2935^{\prime}-45^{\prime}$ and $2969^{\prime}-89^{\prime}$ in the Haldager No. 1 borehole and mainly to the later part of the Portlandian in eastern England.

Genus Scriniodinium Klement, 1957

Scriniodinium pharo (Duxbury, 1977) comb. nov.

1977: Endoscrinium pharo Duxbury, p. 32, pl. 9, fig. 5

Remarks. I agree with Stover and Evitt's (1978) interpretation that Endoscrinium (Klement, 1960) is a junior synonym of Scriniodinium Klement, 1957. Hence the present species is here formally transferred to the latter genus.

Occurrence. Very rare examples of $S$. pharo occur in the giganteus of Norfolk, eastern England. Onshore in England, it is next recorded in the lamplughi Zone and above this zone it is relatively common (always under 5\%) until the albidum Zone where it is rare. Recent unpublished studies show that this species does range into the early Valanginian. In the Haldager No. 1 borehole it occurs consistently from sample $2772^{\prime}-82^{\prime}$ to $2969^{\prime}-89^{\prime}$ and has an isolated occurrence in sample $3180^{\prime}-90^{\prime}$.

\section{Genus Tasmanites Newton 1875}

Tasmanites newtoni group Wall 1965

Remarks. The overall size, the wall thickness and details of the wall structure of the tasmanitids near the Jurassic - Cretaceous boundary vary considerably and in the present instance they are all included under the taxon Tasmanites newtoni group. The presence or absence of large pore - canals does not appear to be a particularly diagnostic feature. In general appearance the present specimens compare most closely to T. tardus Eisenack 1957 and T. newtoni Wall 1965.

Occurrence. In eastern England, tasmanitids occur consistently from the "giganteus" Zone to the runctoni Zone. In Dorset they occur consistently and often abundantly from the "giganteus" Zone to the mutabilis Zone (early Kimmeridgian). Lam and 
Porter (1977) report this group from the pallasioides Zone to the cymodoce Zone of Brora, northeast Scotland. In Haldager No. 1 borehole they occur only at $2866^{\prime}-76^{\prime}$ and $2989^{\prime}-3009^{\prime}$. Tasmanitids are characteristic of the Kimmeridge Clay Formation in the North Sea Basin and are particularly common in the late Portlandian; their occurrence is closely linked to the distribution of Pterospermella aureolata (Cookson \& Eisenack, 1958) Eisenack, 1972 in this formation. core suggests the possibility that this subzone may have been penetrated. Heslertonia heslertonensis (see Davey 1979) is not now considered to have a base in this subzone and probably ranges down to at least the early Valanginian where it possibly grades into the smaller Heslertonia pellucida.

Additional distinctive species characteristic of the Hauterivian include Cymososphaeridium validum, Nematosphaeropsis scala and Spiniferites ramosus primaevus.

Spiniferites ramosus Zone. Cores $2647^{\prime}-57^{\prime}$ and $2667^{\prime}-77^{\prime}$ (Valanginian)

The base of $S$. ramosus, in the deeper sample, is used to define this zone. The presence of Gochteodinia villosa multifurcata is consistent with this zone and the occurrence of Systematophora palmula in the deeper sample suggests an early Valanginian age at this level. The base of Oligosphaeridium is in the higher sample; its absence in the lower sample is similarly suggestive of an early Valanginian age.

The base of Phoberocysta neocomica occurs at $2667^{\prime}-77^{\prime}$ and, when considering its distribution in Davey 1979 , appears to be unusually high. However, Davey, at that time, included forms since attributable to $P$. tabulata in $P$. neocomica and the former species does occur deeper in the borehole.

Spiniferites ramosus/Pseudoceratium pelliferum Zones. Cores $2752^{\prime}-62^{\prime}$ and $2772^{\prime}-82^{\prime}$ (early Valanginian)

Although $S$. ramosus is absent from these cores, the deeper one does nevertheless contain Kleithriasphaeridium simplicispinum and Exochosphaeridium phragmites which are characteristic of this zone. However, the top occurrences of Canningia compta, Scriniodinium pharo and Gonyaulacysta sp. B at this level do suggest the basal part of the $S$. ramosus Zone to $P$. pelliferum Zone of earliest Valanginian age.

The presence of $B$. longicornutum and the lack of the suceeding subzonal markers (Canningia cf. reticulata sensu Duxbury 1977, Subtilisphaera spp. and Ophiobolus sp. A Davey 1979) indicates the presence of the B. longicornutum Subzone. Hystrichogonyaulax cf. cladophora is common in the higher sample and is suggestive of the earlier part of this zone. Discorsia nanna, the base of which is used to define the underlying Kleithriasphaeridium simplicispinum Subzone, was not recorded during this study; hence this subzone could not be identified with certainty. However the occurrence of Muderongia extensiva in the deeper

\section{Pseudoceratium pelliferum Zone. Cores $2822^{\prime}-32^{\prime}$ and $2832^{\prime}-42^{\prime}$ (early \\ Valanginian - late Ryazanian)}

The base of this zone is defined, in the deeper sample by the basal occurrence of $P$. pelliferum. The top occurrence of Occisucysta sp. A. Davey 1979 in the higher sample, indicates the upper part of this zone.

Davey (1979) wrongly considered that Ctenidodi- 


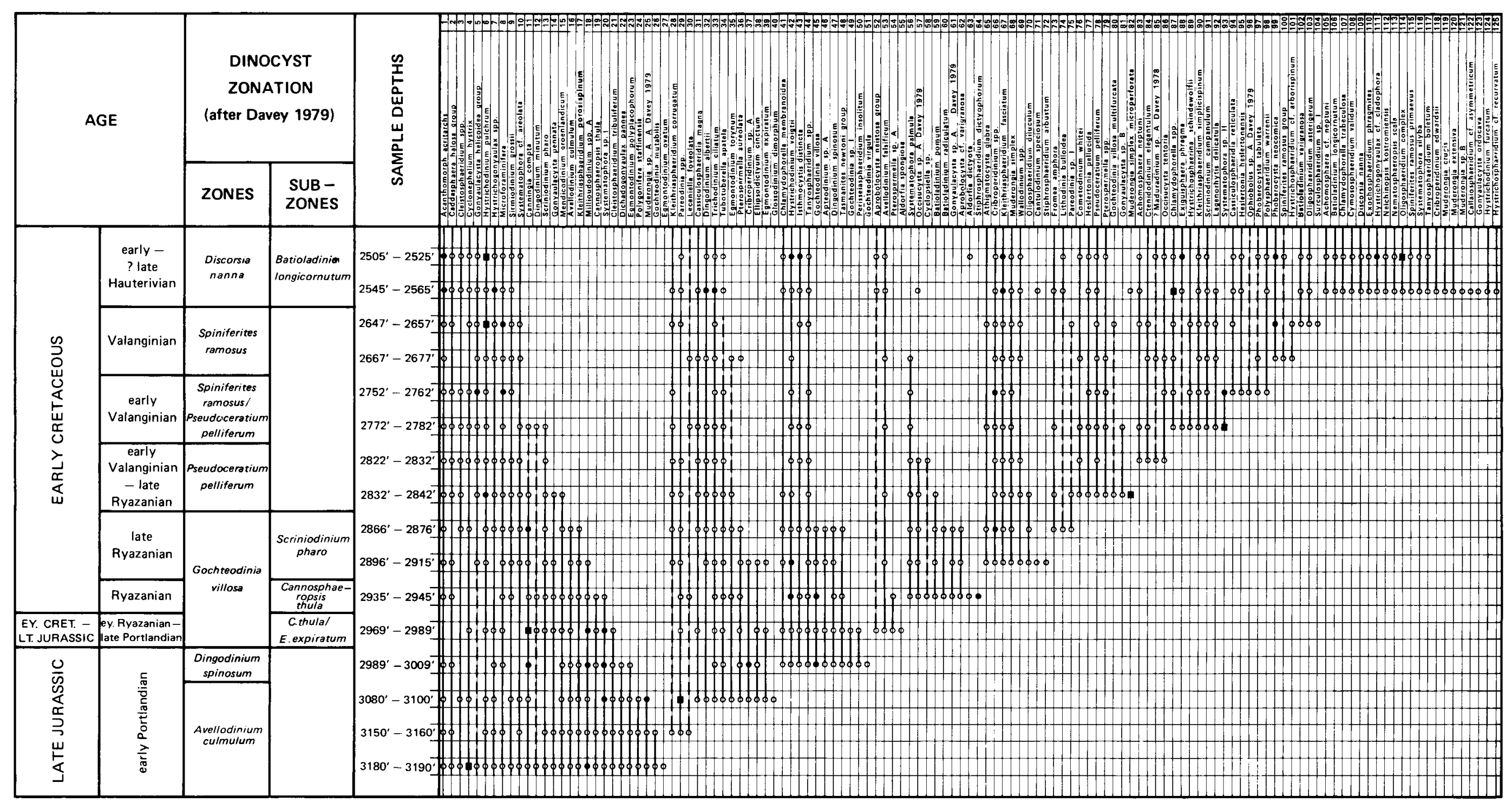

Fig. 3. Distribution-range chart of the microplankton encountered in the Haldager No. 1 borehole. 
nium elegantulum did not occur beneath the Chlamydophorella trabeculosa (Batioladinium longicornutum) Subzone of Hauterivian age. It has since been observed down to the lower part of the $P$. pelliferum (latest Ryazanian) Zone and in the present borehole has a basal occurrence at $2822^{\prime}-32^{\prime}$.

The continued presence of Gochteodinia villosa multifurcata down to $2832^{\prime}-42^{\prime}$ is indicative of an early Valanginian age although a late Ryazanian age cannot be dismissed. Such an age is suggested by Oligosphaeridium diluculum at this level.

\section{Scriniodinium pharo Subzone. Cores $2866^{\prime}-76^{\prime}$ and $2896^{\prime}-915^{\prime}$ (late Ryazanian)}

The top of this zone is identified by the top occurrence of Avellodinium culmulum in core 2866'-76'. Kleithriasphaeridium porosispinum (Kleithriasphaeridium sp. A of Davey 1979) also has a top occurrence at this level and was reported by Davey (op. cit) to mark this boundary. However, it now appears probably, that this species does in fact range into the early Valanginian. The top consistent occurrence of Pterospermella aureolata also occurs in this core. Although it is realised that this is a strongly environmentally controlled form, it does have a practical top occurrence in northwest Europe at the top of the Kimmeridge Clay Formation which is, at its youngest, at the top of this subzone. Additional species first appearing in this core, and consistent with this subzone, include Gonyaulacysta sp. A Davey 1979, Dingodinium spinosum and Gochteodinia villosa.

The absence of Cannosphaeropsis thula in core $2896^{\prime}-915^{\prime}$ indicates that this core is similarly attributable to the $S$. pharo Subzone. Several forms have basal occurrences in this core and include Kleithriasphaeridium corrugatum, K. fasciatum, Muderongia simplex and Athigmatocysta glabra.

Although the first three species were considered by Davey (op. cit) to have stratigraphical bases in the overlying Pseudoceratium pelliferum Zone, there is now strong evidence to suggest in this core, and the overlying core, that their bases are indeed lower and in the $S$. pharo Subzone. The base of Oligosphaeridium diluculum (only recorded onshore from the stenomphalus Zone) is in this core and Stiphrosphaeridium arbustum (recorded onshore from the icenii and stenomphalus Zones) only occurs here; both these occurrences are consistent with the $S$. pharo Subzone determination.
Cannosphaeropsis thula Subzone. Core 2935'-45' (Ryazanian)

The top of this subzone in this borehole is marked by the first downhole occurrence of the nominative species. The following species have their basal occurrences at this level:- Batioladinium radiculatum, Systematophora palmula, Occisucysta sp. A Davey 1979 and Gonyaulacysta sp. A Davey 1979. Both the latter two species have their basal stratigraphical occurrences in the stenomphalus Zone of England. Hence, there is here strong evidence to suggest they do range slightly lower in the Ryazanian. $B$. radiculatum has only been recorded onshore in the runctoni and icenii Zones and Stiphrosphaeridium arbustum, which is common in this core, is only found abundantly in the runctoni and kochi Zones. C. thula has also been found extremely rarely in the icenii Zone. Hence the top of this subzone may be slightly higher than reported by Davey (op. cit) and be within the lower part of the icenii Zone.

\section{Cannosphaeropsis thula/Egmontodinium expiratum Subzones. Core 2969'-89' (early Ryazanian - Portlandian)}

These two subzones are always difficult to differentiate because of the rarity of the marker species, $E$. expiratum. It does occur in this core, but also in core $2896^{\prime}-915^{\prime}$ where it is probably reworked. Canningia compta occurs abundantly for the first time at $2969^{\prime}-89^{\prime}$ and has been recorded in similar numbers from Zones oppressus to stenomphalus onshore. It is, however, recognised that this is a somewhat facies controlled form and is particularly characteristic of "nearshore" shallow water sediments. Perisseiasphaeridium insolitum is also present and onshore has only been recovered from the "giganteus" and oppressus Zones. This suggests that this core could belong to the lower part of the E. expiratum Subzone.

\section{Dingodinium spinosum Zone. Core $2989^{\prime}-3009^{\prime}$ (early Portlandian)}

The marker species for this zone, Dichadogonyaulax pannea, has its top occurrence in this core and indicates that sediments of early Portlandian age are present. However there is evidence, by the presence of Gochteodinia virgula (onshore in the oppressus and lamplughi zones), that younger aged Portlandian sediments may also be present in this core. This conclusion is strengthened by Gochteodinia villosa which 
occurs commonly in this core. Although this species is known from the "giganteus" Zone of onshore England, it is only present in any abundance above this level.

Additional species having basal occurrences in this core are Dingodinium spinosum and Perisseiasphaeridium insolitum which both have bases onshore in the "giganteus" Zone. Egmontodinium polyplacophorum, which has a top occurrence onshore in the oppressus Zone, similarly has a youngest occurrence in this core.

\section{Avellodinium culmulum Zone. Cores $3080^{\prime}-100^{\prime}$ to $3180^{\prime}-90^{\prime}$ (early Portlandian)}

This zone is identified by the absence of Dingodinium spinosum, the top occurrence of Polygonifera staffinensis in core $3080^{\prime}-100^{\prime}$ and the continued presence of $A$. culmulum to the base of the cored sequence at $3180^{\prime}-90^{\prime}$. Of significance in the highest core is the top and common occurrence of Muderongia sp. A. Davey 1979 which, for practical purposes, is regarded as marking the top of this zone. Several species have their basal occurrences in this core but these are regarded primarily as being only of local interest.

Core $3150^{\prime}-60^{\prime}$ contains the top occurrence of Gochteodinia mutabilis which onshore is known only from the albani Zone and late Kimmeridgian.

Although A. culmulum is found in core $3180^{\prime}-90^{\prime}$, the distinctive species Egmontodinium ovatum also occurs here. This species has only previously been observed in pre-Portlandian sediments and suggests that the base of the A. culmulum Zone may be within the uppermost Kimmeridigian. Scriniodinium pharo occurs in this core and has previously been found to have a stratigraphical base in the "giganteus" Zone; its occurrence here could be possibly due to contamination.

\section{Acknowledgements}

The author would like to thank sincerely the Danish Geological Survey for making the samples available for study and also being so patient in waiting for the present publication to be completed. The research facilities at the Institute of Geological Science (Leeds, England), Robertson Research (Llandudno, North Wales) and Shell U. K. Exploration and Production (London) are all gratefully acknowledged.

\section{Literature}

(All references to dinocysts mentioned in the text but not listed below are to be found in Lentin and Williams 1973, 1975, 1977).

Casey, R. 1973: The ammonite sucession at the Jurassic - Cretaceous boundary in eastern England: The Boreal Lower Cretaceous (Seal House Press, London; R. Casey and P. F. Rawson editors), pp. 193-266.

Davey, R. J. 1978: Marine Cretaceous palynology of Site 361, DSDP Leg 40, off southwestern Africa. In Bolli, H. M, Ryan, W.B.F. et al., Initial Reports of the Deep Sea Drilling Project, 40 , pp. $883-914$.

Davey, R. J. 1979: The stratigraphic distribution of dinocysts in the Portlandian (latest Jurassic) to Barremian (Early Cretaceous) of northwest Europe. - AASP Contribution Series, 5B, pp. 49-81.

Duxbury, S. 1979: Three new genera of dinoflagellate cysts from the Speeton Clay (Early Cretaceous) of Speeton, England. Micropaleontology, 25, pp. 198-205.

Duxbury, S. 1979: On Lagenorhytis Duxbury nom. mov. - Taxon, 28 , p. 587.

Duxbury, S. 1980: Barremian phytoplankton from Speeton, east Yorkshire. - Palaeontographica, 173, pp. 107-146.

Eisenack, A. 1957: Mikrofossilien in organischer Substanz aus dem Lias Schwabens (Süddeutschland). - Neues Jahrb. Min. Geol. Pal., 15, pp. 239-247.

Eisenack, A. 1972: Kritische Benerkung zur Gattung Pterospermopsis (Chlorophyta, Prasinophyceae), - Neues Jahrb. Geol. Paläont. Mh., H.10. pp. 596-601.

Erdtman, G. 1948: Did Dicotyledonous plants exist in early Jurassic times? - Geol. For. Forh., 70, pp. 265-271.

Fisher, M. J. \& Riley, L. A. 1980: The stratigraphic distribution of dinoflagellate cysts at the boreal Jurassic - Cretaceous boundary. - IV Int. Palynol. Conf., Lucknow (1976-77), 2, pp. 313-329.

Kemper, E., Rawson P. F. \& Thieuloy, J.-P. 1981: Ammonites of Tethyan ancestry in the early Lower Cretaceous of north-west Europe. - Palaeontology, 24, pp. 251-311.

Lentin, J. K. \& Williams, G. L. 1973: Fossil dinoflagellates; index to genera and species. - Geological Survey of Canada Paper, 73-42, pp. 1-176.

Lentin, J. K. \& Williams, G. L. 1975: Fossil dinoflagellates; index to genera and species. Supplement 1. - Canadian Journal of Botany, 53, pp. 2147-2157.

Lentin, J. K. \& Williams, G. L. 1977: Fossil dinoflagellates; index to genera and species, 1977 edition. - Bedford Institute of Oceanography Report B1-R-77-8, pp. 1-209.

Lundblad, B. 1954: Contributions to the geological history of the Hepaticae. Fossil Marchantiales from the Rhaetic Liassic coalmines of Skromberga (Prov. of Scania), Sweden, - Sven. Bot, Tidskr., 48, pp. 381-417.

McIntyre, D. J. \& Brideaux W. W. 1980: Valanginian miospore and microplankton assemblages from the northern Richardson Mountains, District of Mackenzie, Canada. - Geological Survey of Canada Bulletin, 320, pp. 1-57.

Michelsen, O. 1978: Stratigraphy and distribution of Jurassic deposits of the Norwegian-Danish Basin. - Danm. geol. Unders., Ser. B, No. 2, pp. 1-35.

Neale, J. W. 1974: Cretaceous: The Geology and Mineral Resources of Yorkshire (Yorkshire Geological Society, Leeds, D. H. Rayner \& J. E. Hemingway editors), pp. 225-243.

Norris, G. 1978: Phylogeny and a revised supra-generic classifica- 
tion for Triassic - Quaternary organic - walled dinoflagellate cysts (Pyrrhophyta). Part II. Families and sub-orders of fossil dinoflagellates. Neues Jahrb. Geol. Paläont. Abh., 156, pp. $1-30$.

Rawson, P. F. et al. 1978: A correlation of the Cretaceous rocks in the British Isles. - Geol. Soc. Lond. Spec. Rep., 9, pp. 1-70.

Raynaud, J. F. 1978: Principaux dinoflagellés caracteristiques du Jurassique Superieur d'Europe du nord. - Palinologia, 1, pp. 387-405.

Riley, L. A. 1974: A palynological investigation of Upper Jurassic - basal Cretaceous sediments from England, France and Iberia. - Ph. D. thesis, Open University (unpublished).

Riley, L. A. 1979: Dinocysts from the Upper Kimmeridgian (pec- tinatus Zone) of Marton, Yorkshire. - Mercian Geol., 7, pp. 219-222.

Sorgenfrei, T. \& Buch, A. 1964: Deep tests in Denmark 1935-1959. - Danm. geol. Unders., III raekke, pp. 1-146.

Stover, L. E. \& Evitt, W. R. 1978: Analyses of pre-Pleistocene organic-walled dinoflagellates. - Stanford University Publications, Geological Sciences, 15, pp. 1-300.

Torrens, M. S. (Ed) 1969: Excursion No. 1 Guide for Dorset and South Somerset. - International Field Symposium on the British Jurassic, pp. 1-71.

Wimbledon, W. A. \& Cope, J. C. W. 1978: The ammonite faunas of the English Portland beds and the zonation of the Portlandian Stage - Jl. geol. Soc. Lond., 135, pp. 183-190. 


\section{Plate 1}

All magnifications $\times 500$. All type material is stored in the collections of the Institute of Geological Sciences, Leeds.

Systematophora palmula sp. nov.

Figs. 1-3 Slide SAL 4639/III, holotype.

Fig. 4. Slide SAL 4639/1, Haldager No. 1 borehole, core depth 2896'-2915'; Ryazanian, Denmark.

\section{Systematophora cf. areolata Klement}

Fig. 5. Slide 4635/II, Haldager No. 1 borehole, core depth 2772'-82'; Valanginian, Denmark.

Fig. 6. Slide 4638/III, Haldager No. 1 borehole, core depth $2866^{\prime}-76^{\prime}$; Ryazanian, Denmark. Interference contrast.

\section{Systematophora $\mathrm{sp.} \mathrm{I}$}

Figs. 7-9. Slide Warlingham VI, Warlingham borehole, Surrey, core depth 2285' 7'" Upper Kimmeridge Clay, Kimmeridgian (? rotunda Zone).

\section{Systematophora sp. II}

Figs. 10, 11. Slide SAL 4635/II, Haldager No. 1 borehole, core depth $2772^{\prime}-82^{\prime}$; Valanginian, Denmark. Fig. 11, phase contrast.

Oligosphaeridium asterigerum (Gocht) Davey \& Williams

Fig. 12. Slide SAL 4628/I, Haldager No. 1 borehole, core depth $2505^{\prime}-25^{\prime}$; Hauterivian, Denmark. Note solid first postcingular process $\left(1^{\prime \prime \prime}\right)$ on lower right of specimen. 
Plate 1
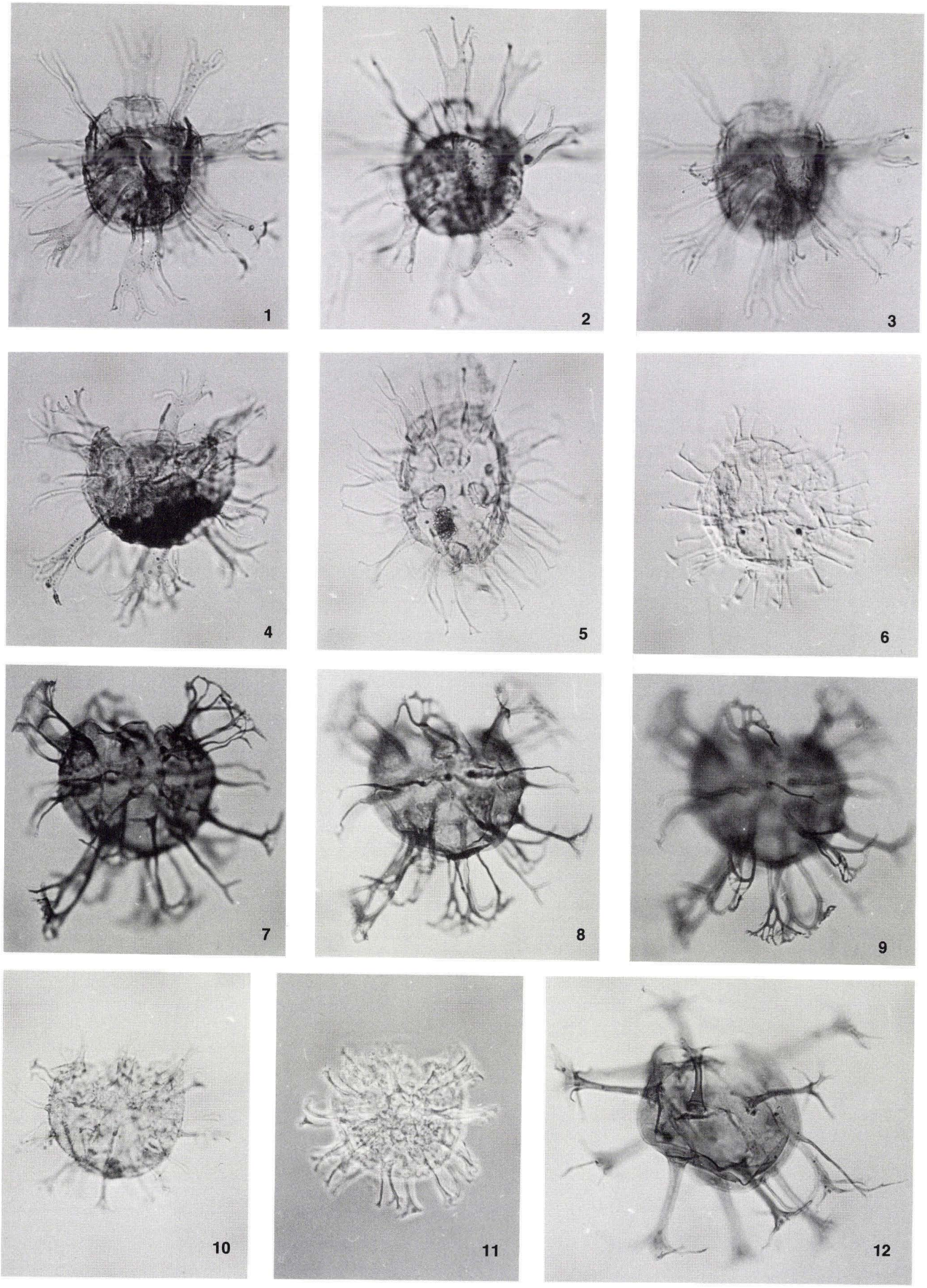
Plate 2

All magnifications $\times 500$.

Oligosphaeridium diluculum sp. nov.

Oligosphaeridium pulcherrimum sensu Ioannides et al. 1977

Figs. 1, 2. Slide SAL 4638/III, holotype

Fig. 3. Slide SAL 5003/1, Sandringham Sands, Ryazanian (stenomphalus Zone); Mintlyn Wood Road Cutting, Kings Lynn By-Pass, Norfolk.

Fig. 4. Slide SAL 4638/II, Haldager No. 1 borehole, core depth 2866'-76'; Ryazanian, Denmark.

Fig. 5. Slide SAL 4639/I, Haldager No. 1 borehole, core depth 2896'-2915'; Ryazanian, Denmark.

Olgosphaeridium sp. I

Figs. 6, 7. Slide Sp. E/1, Bed E, Speeton Clay, Ryazanian; Speeton, Yorkshire.

Fig. 8. Slide SAL 5009/1, Bed 6 (Casey 1973), Sandringham Sands; Ryazanian (runctoni Zone); Manor Farm, Norfolk.

Fig. 9, Slide SAL 5426/1, North Wooton borehole, core depth $41.30 \mathrm{~m}$; Kimmeridgian (wheatleyensis Zone). Note funnel-shaped processes, complexly and irregularly divided distally.

Stiphrosphaeridium dictyophorum (Cookson \& Eisenack) comb. nov.

Figs. 10, 11. Slide 5009/2, Bed 6 (Casey 1973), Sandringham Sands; Ryazanian (runctoni Zone); Manor Farm, Norfolk.

Figs. 12, 13. Slide 5258/1, Bed 6 (Casey 1973), Sandringham Sands; Ryazanian (runctoni Zone); Manor Farm, Norfolk. 12 , two paraplates bearing restricted annulate process complexes. 13, detached operculum having four, basically solid, processes. 
Plate 2
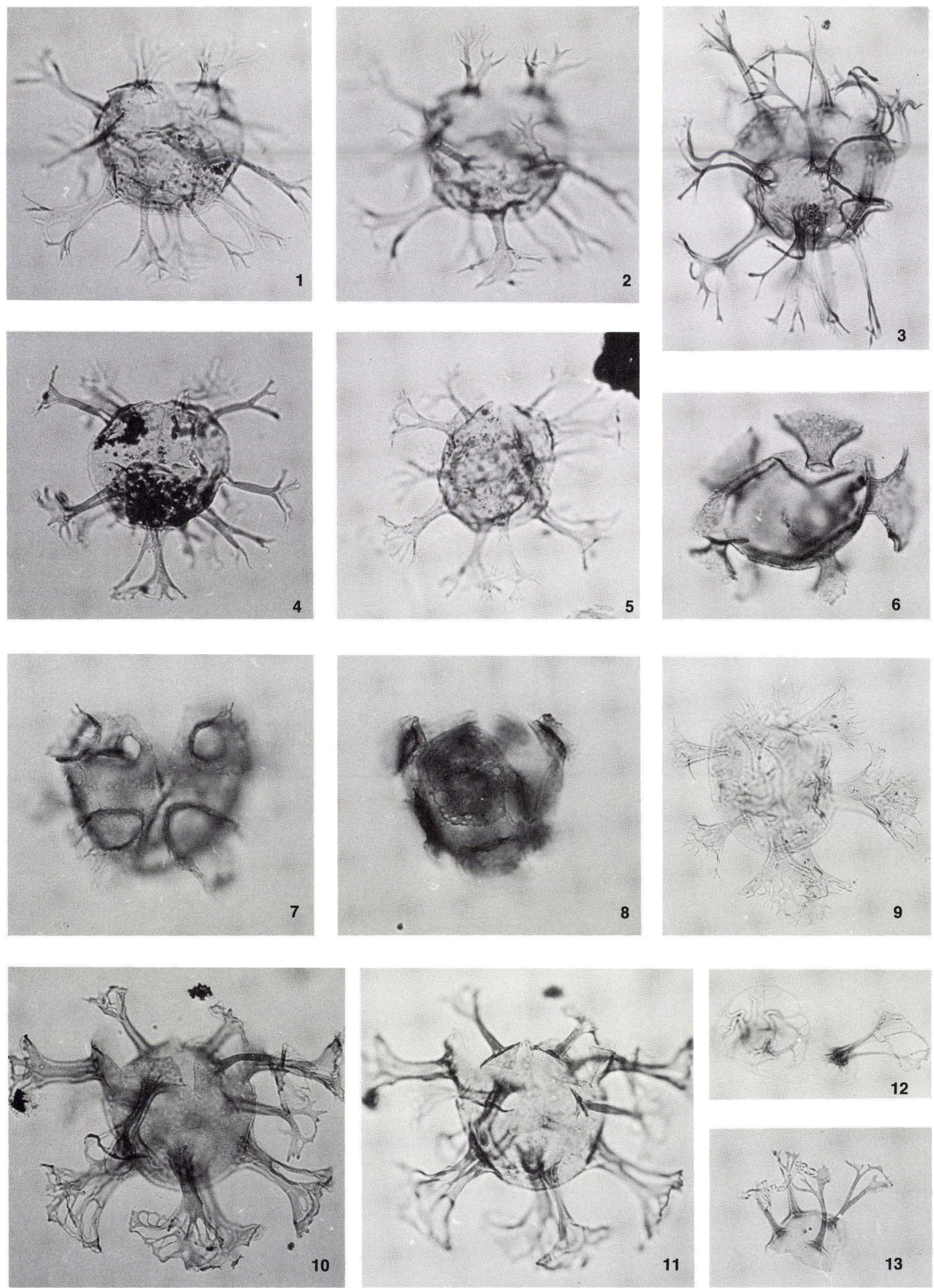
Plate 3

All magnifications $\times 500$.

Stiphrosphaeridium arbustum sp. nov.

Figs. 1, 2. Slide SAL 4639/III, holotype.

Figs. 3, 4. Slide SAL 4639/I, Haldager No. 1 borehole, core depth 2896'-2915'; Ryazanian, Denmark.

Cymososphaeridium validum sp. nov.

Figs. 5, 8, 11. Slide 4628/I, holotype.

Fig. 6. Slide 4628/I, Haldager No. 1 borehole, core depth $2505^{\prime}-25^{\prime}$; Hauterivian, Denmark. Interference contrast.
Surculosphaeridium sp. I

Fig. 7. Slide 4632/I, Haldager No. 1 borehole, core depth $2647^{\prime}-57^{\prime}$; Valanginian, Denmark.

Fig. 10. Slide 4637/IV, Haldager No. 1 borehole, core depth $2832^{\prime}-42^{\prime}$; early Valanginian - late Ryazanian, Denmark.

Cymososphaeridium sp. I

Figs. 9, 12. Slide Sp. D3 base/1', Bed D3, Speeton Clay; early Valanginian; Speeton, Yorkshire. 
Plate 3
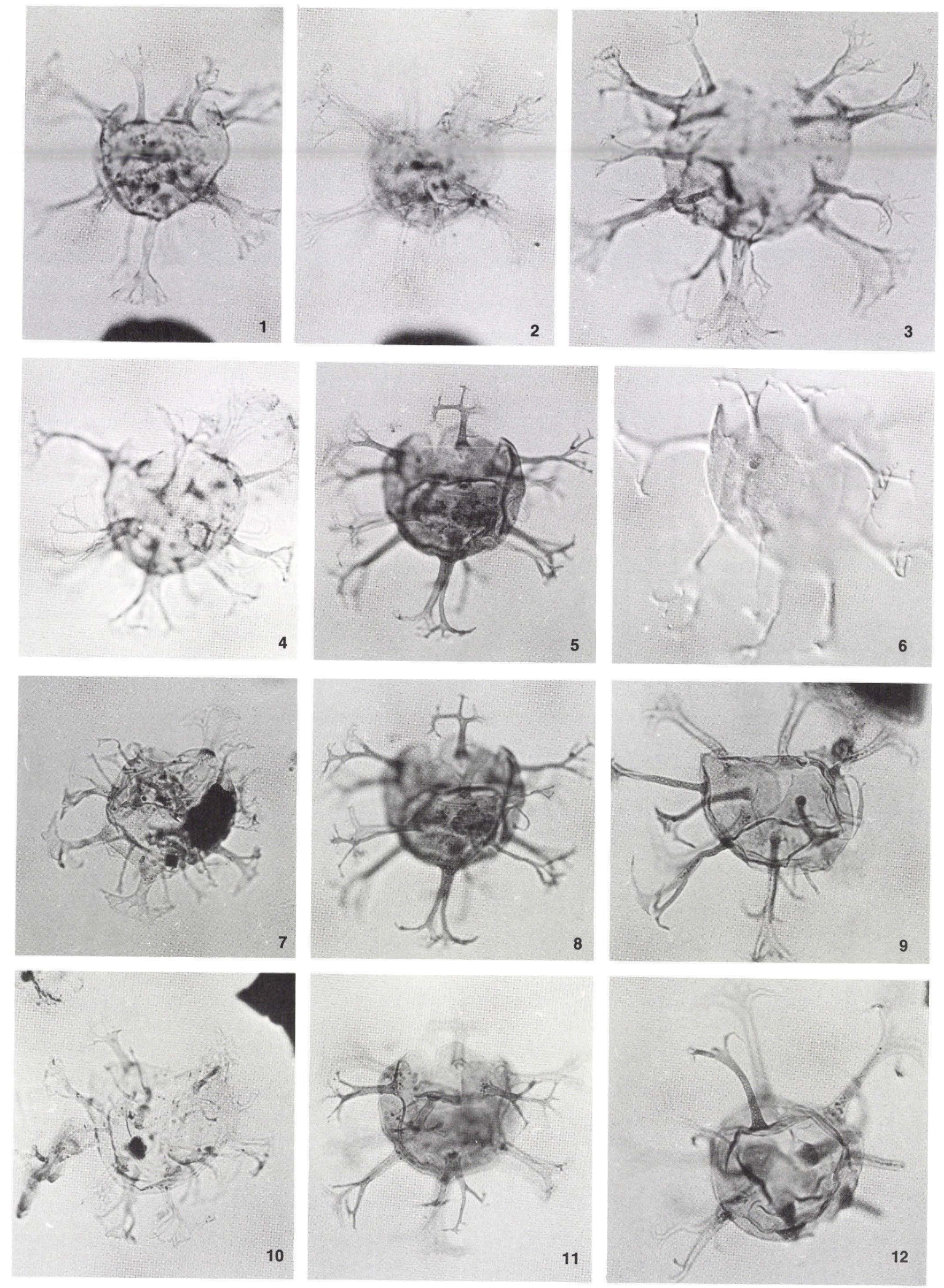


\section{Plate 4}

All magnifications $\times 500$.

\section{Surculosphaeridium sp. II}

Fig. 1. Slide Sp. D3 middle/1, Bed D3, Speeton Clay; early Valanginian; Speeton, Yorkshire.

Fig. 2. Slide Sp. D4/1, Bed D4, Speeton Clay; early Valanginian; Speeton, Yorkshire.

Surculosphaeridium sp. III

Figs. 3, 4. Slide Sp. D4 pale stripe/3', Bed D4, Speeton Clay; early Valanginian; Speeton, Yorkshire. 4, note clearly defined paracingular processes.

Figs. 5, 6. Slide Sp. D3 base/1', Bed D3, Speeton Clay; early Valanginian; Speeton, Yorkshire. Note arcuate bases to larger processes.

\section{Perisseiasphaeridium sp. I}

Fig. 7. Slide SAL 5433/1, North Wooton borehold, core depth $55.50 \mathrm{~m}$; Kimmeridgian (autissiodorensis Zone). Note very complexly branching tubiform processes and solid parasulcal and paracingular processes. Phase contrast.

Perisseiasphaeridium insolitum sp. nov.

Fig. 8. Slide SAL 5254/2, holotype.

Figs. 9, 10. Slide SAL 5254/1, Bed 1 (Casey 1973), Spilsby Sandstone, Portlandian ("giganteus" Zone); Nettleton Top Barn Pit, Lincolnshire.

Cantulodinium speciosum Alberti

Fig. 11. Slide 4639/I, Haldager No. 1 borehole, core depth $2896^{\prime}-2915^{\prime}$; Ryazanian, Denmark. Note the apparent loss of two intercalary paraplates in archaeopyle formation.

\section{Pareodinia sp. I}

Figs. 12, 13. Slide 4638/II, Haldager No. 1 borehole, core depth $2866^{\prime}-76^{\prime}$; Ryazanian, Denmark. 13, interference contrast.

Fig. 14. Slide 4632/I, Haldager No. 1 borehole, core depth $2647^{\prime}-57^{\prime}$; Valanginian, Denmark. Interference contrast. 
Plate 4
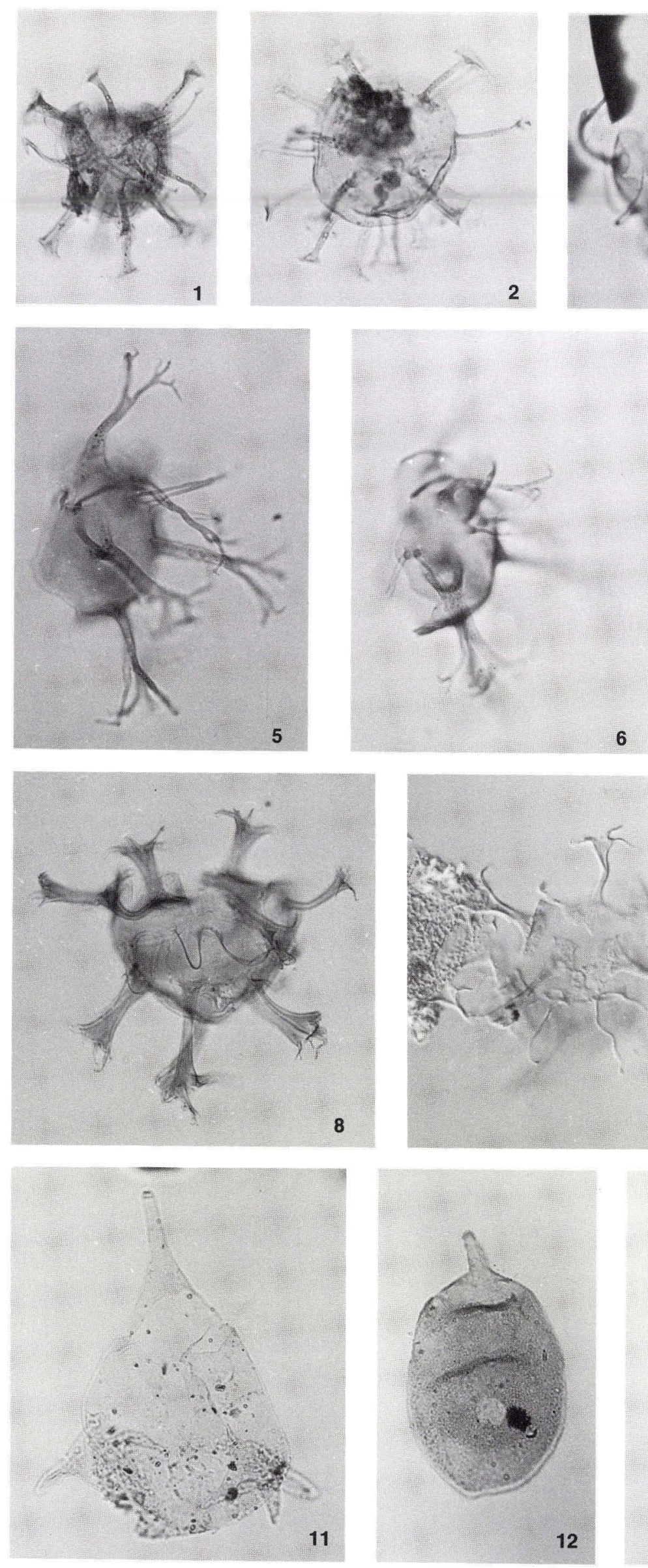
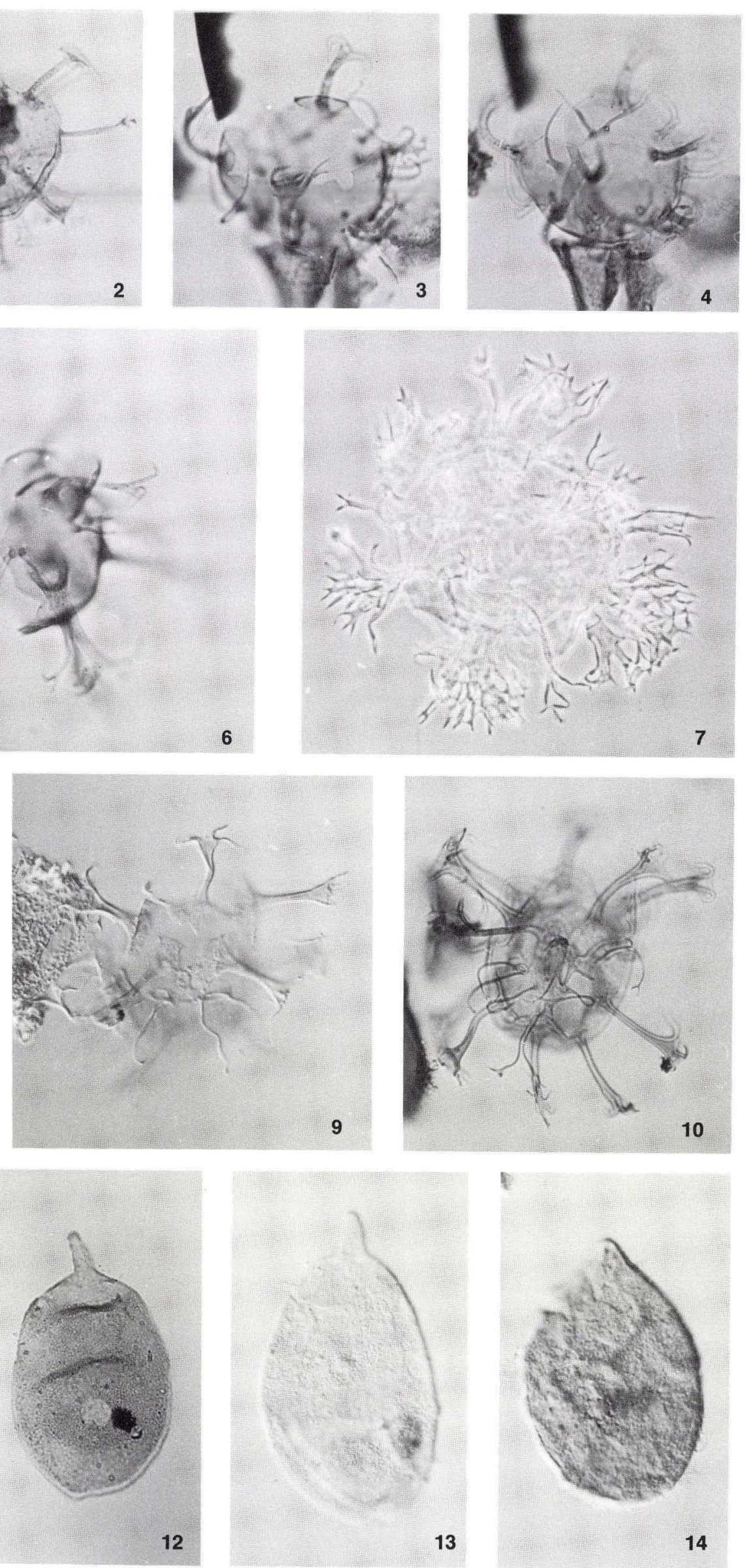

4 D.G.U. serie B, nr. 6 
Plate 5

All magnifications $\times 500$.

Batioladinium radiculatum sp. nov.

Fig. 1. Slide SAL 4640/I, Haldager No. 1 borehole, core depth 2935'-45'; Ryazanian, Denmark.

Fig. 7. Slide SAL 4640/II, Haldager No. 1 borehole, core depth 2935'-45'; Ryazanian, Denmark.

Fig. 8. Slide SAL 4640/I, holotype.

Fig. 9. Slide SAL 5258/1, Bed 6 (Casey 1973), Sandringham Sands; Ryazanian (runctoni Zone); Manor Farm, Norfolk. Apical archaeopyle developed.

Batioladinium pomum sp. nov.

Fig. 2. Slide SAL 4639/I, Haldager No. 1 borehole, core depth 2896'-2915'; Ryazanian, Denmark.

Fig. 3. Slide SAL 4640/I, holotype.

Fig. 4. Slide SAL 4638/II, Haldager No. 1 borehole, core depth $2866^{\prime}-76^{\prime}$; Ryazanian, Denmark.
Batioladinium varigranosum (Duxbury) comb. nov.

Fig. 5. Slide Sp. D3 top/I', Bed D3, Speeton Clay; early Valanginian; Speeton, Yorkshire.

Fig. 6. Slide SAL 4628/I, Haldager No. 1 borehole, core depth $2505^{\prime}-25^{\prime}$; Hauterivian, Denmark. Apical archaeopyle developed.

Batioladinium cf. varigranosum (Duxbury) comb. nov.

Fig. 10. Slide SAL 4640/I, Haldager No. 1 borehole, core depth 2935'-45'; Ryazanian, Denmark. Interference contrast.

Batioladinium sp. I

Fig. 11. Slide SAL 5260/4, Sandringham Sands; Ryazanian (kochi Zone); cut off channel, West Abbey Station, Norfolk. Apical archaeopyle developed

Fig. 12. Slide Sp. D3 top/I'; Bed D3, Speeton Clay; early Valanginian; Speeton, Yorkshire. Apical archaeopyle developed.

Fig. 13. Slide Sp. D3 base/I', Bed D3, Speeton Clay; early Valanginian; Speeton, Yorkshire. Apical archaeopyle developed. 
Plate 5
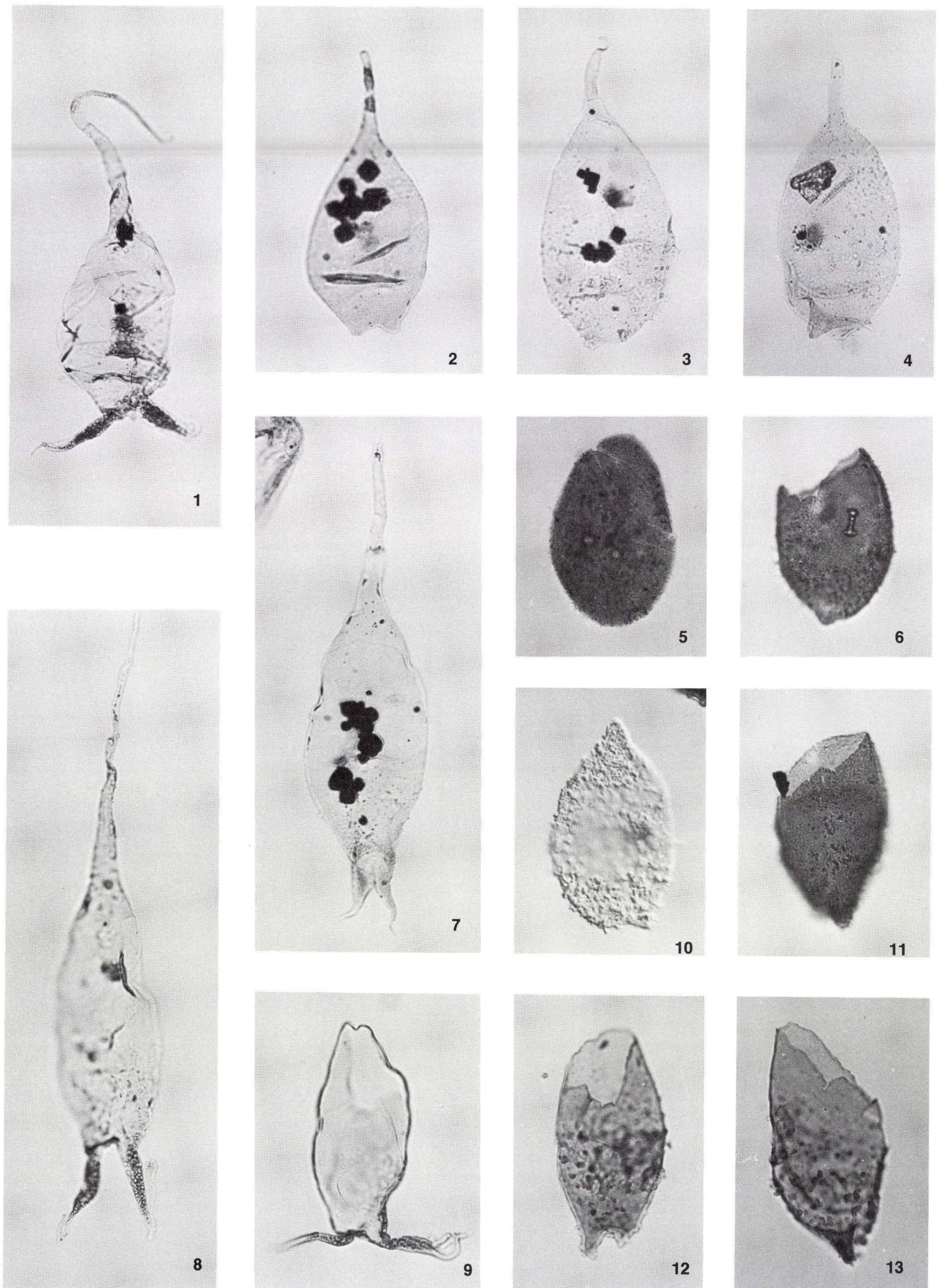
Plate 6

All magnifications $\times 500$.

Gochteodinia villosa (Vozzhennikova) Norris

Fig. 1. Slide SAL 5259/2, Bed 10 (Casey 1973), Sandringham Sands; Ryazanian (stenomphalus Zone); Mintlyn Sands, Norfolk. Unusually large specimen.

Fig. 4. Slide SAL 5260/4, Sandringham Sands; Ryazanian (kochi Zone); cut off channel, West Abbey Station, Norfolk. Note bulbous extremities to the spines.

Fig. 5. Slide SAL 5254/1, Bed 1 (Casey 1973), Spilsby Sandstone, Portlandian ("giganteus" Zone); Nettleton Top Barn Pit, Lincolnshire. Note very short, blunt spines.

Fig. 6. Slide SAL 4640/II, Haldager No. 1 borehole, core depth $2935^{\prime}-45^{\prime}$; Ryazanian, Denmark. Note 2 I archaeopyle and short, acuminate processes. Interference contrast.

Gochteodinia virgula sp. nov.

Figs. 2, 7, 10. Slide SAL 5014/2, holotype.

Figs. 3, 8, 11. Slide SAL 5018/1, Haldager No. 1 borehole, core depth 2989'-3009'; Portlandian, Denmark.
Gochteodinia mutabilis (Fisher \& Riley) comb. nov

Figs. 9, 12. Slide SAL 5024/1, Haldager No. 1 borehole, core depth $3150^{\prime}-60^{\prime}$; Portlandian, Denmark. Note short, very irregular spines.

Gochteodinia villosa subsp. multifurcata nov.

Fig. 13. Slide Sp. "Upper D4"/1', type.

\section{Gochteodinia sp. I}

Fig. 14. Slide SAL 4641/II, Haldager No. 1 borehole, core depth 2969'-89'; early Ryazanian - late Portlandian, Denmark. Note distal trabeculae.

Fig. 15. Slide SAL 5018/1, Haldager No. 1 borehole, core depth 2989'-3009'; Portlandian, Denmark. Note branching processes with occasional trabeculae. 

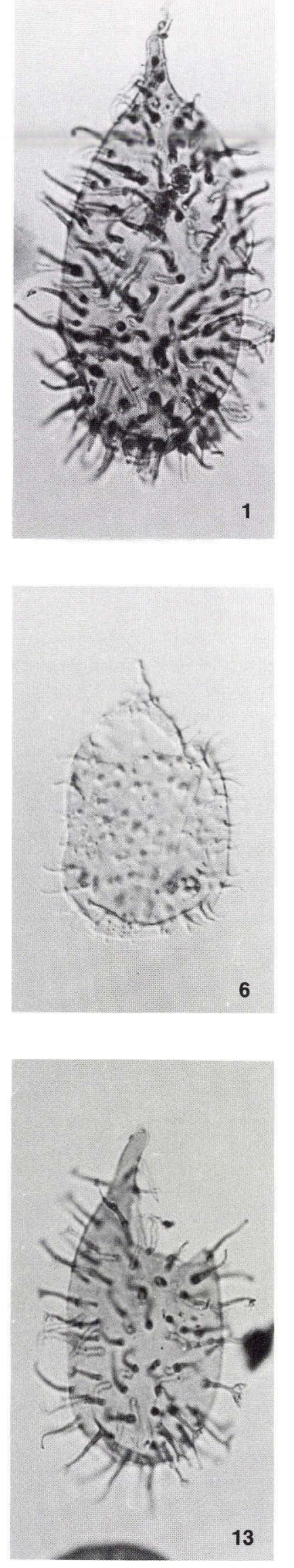
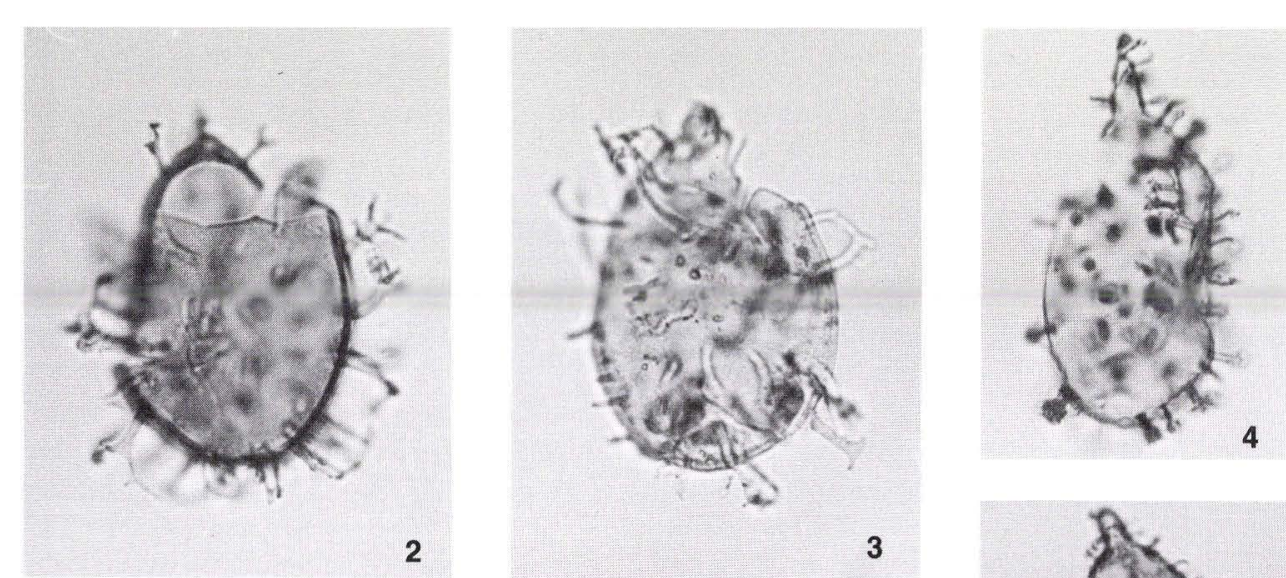

2
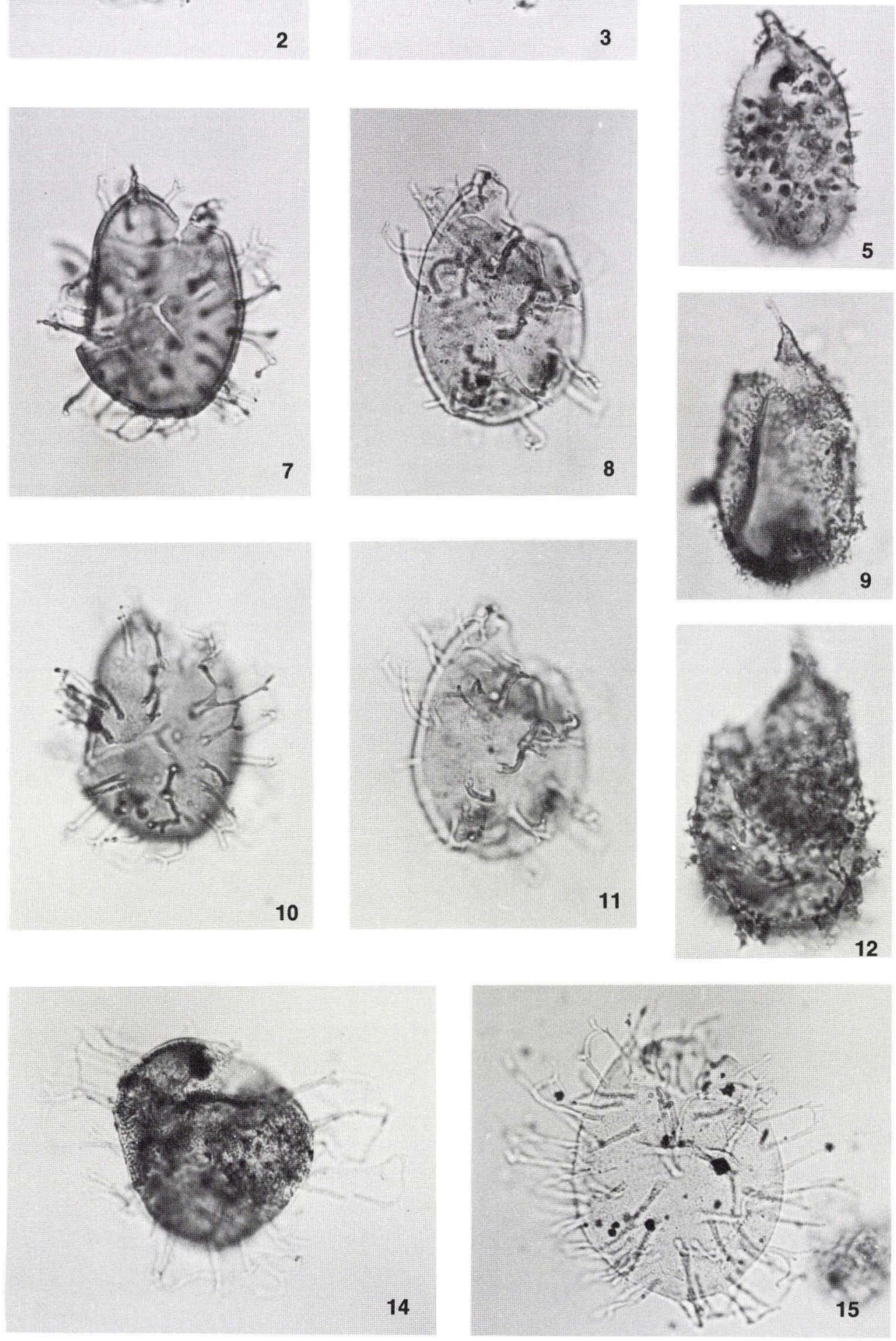
Plate 7

All magnifications $\times 500$.

Gochteodinia sp. II

Figs. 1-4. Slide SAL 5254/1, Bed 1 (Casey 1973), Spilsby Sandstone; Portlandian ("giganteus" Zone); Nettleton Top Barn Pit, Lincolnshire. 1, 2, 4, note peritabular crests.

Aprobolocysta neistosa Duxbury

Figs. 5, 6. Slide SAL 4629/3, Haldager No. 1 borehole, core depth $2545^{\prime}-65^{\prime}$; Hauterivian, Denmark. 5, ventral view. 6, dorsal view.

Fig. 7. Slide Sp. D3 top/I', Bed D3, Speeton Clay; early Valanginian; Speeton, Yorkshire.

Aldorfia spongiosa (McIntyre \& Brideaux) comb. nov.

Fig. 8. Slide SAL 4641/II, Haldager No. 1 borehole, core depth $2969^{\prime}-89^{\prime}$; early Ryazanian - late Portlandian, Denmark. Note large precingular archaeopyle and characteristic ornamentation.

Figs. 9, 10. Slide SAL 5254/1, Bed 1 (Casey 1973), Spilsby Sandstone; Portlandian ("giganteus" Zone); Nettleton Top Barn Pit, Lincolnshire. 9, dorsal view with operculum partially detached. 10 , ventral view.

Apteodinium sp. A

Fig. 11. Slide SAL 5254/1, Bed 1 (Casey 1973), Spilsby Sandstone; Portlandian ("giganteus" Zone); Nettleton Top Barn Pit, Lincolnshire. Datached operculum; note pitted or perforate surface appearance.

Figs. 12, 16. Slide SAL 5254/3, Bed 1 (Casey 1973), Spilsby Sandstone; Portlandian ("giganteus" Zone); Nettleton Top Barn Pit, Lincolnshire. 12, ventral view; note apical horn which is an extension of the wall. 16, medial view; note thick, spongy wall.

\section{Aldorfia sp. A}

Figs. 13-15. Slide SAL 5254/3, Bed 1 (Casey 1973), Spilsby Sandstone; Portlandian, ("giganteus" Zone); Nettleton Top Barn Pit, Lincolnshire. 13, dorsal view. 14, ventral view. 15, medial view. 
Plate 7
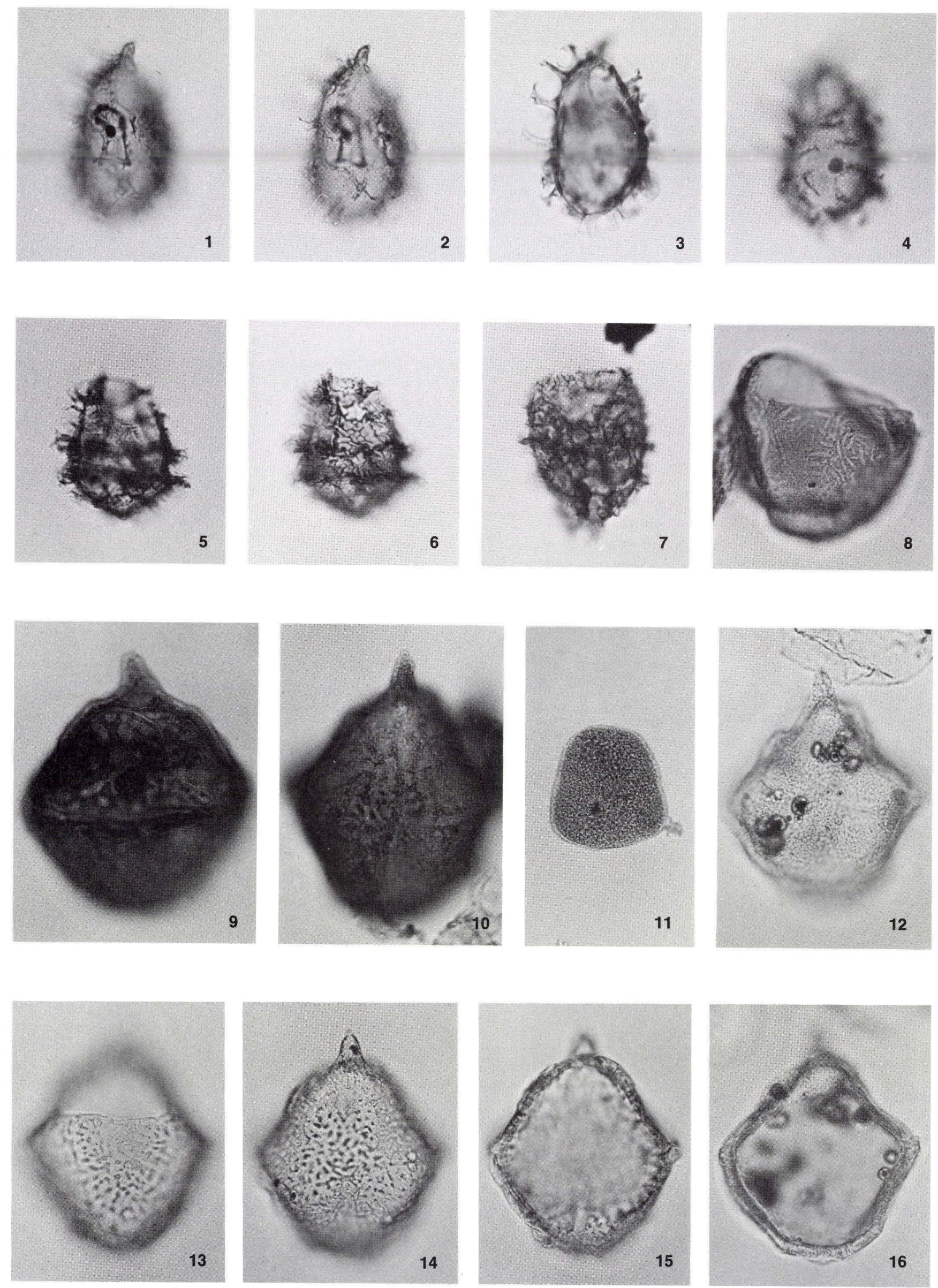
Plate 8

All magnifications $\times 500$.

Isthmocystis distincta Duxbury

Fig. 1. Slide SAL 4629/4, Haldager No. 1 borehole, core depth 2545'-65'; Hauterivian, Denmark. Apical view; note detachment of precingular paraplates in archaeopyle formation, parasulcal/apical region still in place and membranous paracingular flange.

Fig. 2. Slide SAL 4628/1, Haldager No. 1 borehole, core depth $2505^{\prime}-25^{\prime}$; Hauterivian, Denmark. Lateral view; apical region, with small apical horn visible, and attached to cyst by the parasulcal region.

Canningia compta sp. nov.

Fig. 3. Slide SAL 5011/1, holotype.

Figs. 4, 5. Slide SAL 5009/2, Bed 6 (Casey 1973), Sandringham Sands; Ryazanian (runctoni Zone); Manor Farm, Norfolk. 4, ventral view; note parasulcus and parasulcal notch.

Fig. 6. Slide SAL 4641/II, Haldager No. 1 borehole, core depth 2969'-89'; early Ryazanian - late Portlandian, Denmark. Complete specimen, with partially detached operculum.
Cannosphaeropsis thula sp. nov.

Fig. 7. Slide SAL 4641/I (MPK 1272), Haldager No. 1 borehole, core depth 2969'-89'; early Ryazanian - late Portlandian, Denmark. Lateral view; precingular archaeopyle to the northeast.

Figs. 8-11. Slide SAL 5260/4, holotype. 8, dorsal view. 9, dorso-medial view. 10 , ventral view. 11 , distal ventral view illustrating trabeculae.

Chlamydophorella membranoidea Vozzhennikova

Fig. 12. Slide SAL 5258/1, Bed 6 (Casey 1973), Sandringham Sands. Ryazanian (runctoni Zone); Manor Farm, Norfolk. Note offset antapical corona.

Egmontodinium expiratum sp. nov.

Figs. 13, 14. Slide GB 424/2, holotype. 13, dorsal view. 14, ventral view.

Fig. 15. Slide 5009/1, Bed 6 (Casey 1973), Sandringham Sands; Ryazanian (runctoni Zone); Manor Farm, Norfolk. A more spinose variety than usual although the crests are still clearly visible.

Fig. 16. Slide GB 424/1, Bed J (Arkell 1933), Cherty Series; Portlandian, kerberus Zone; Tilly Whim Caves, Dorset. Specimen with very reduced spines and a vacuolated appearance. 
Plate 8
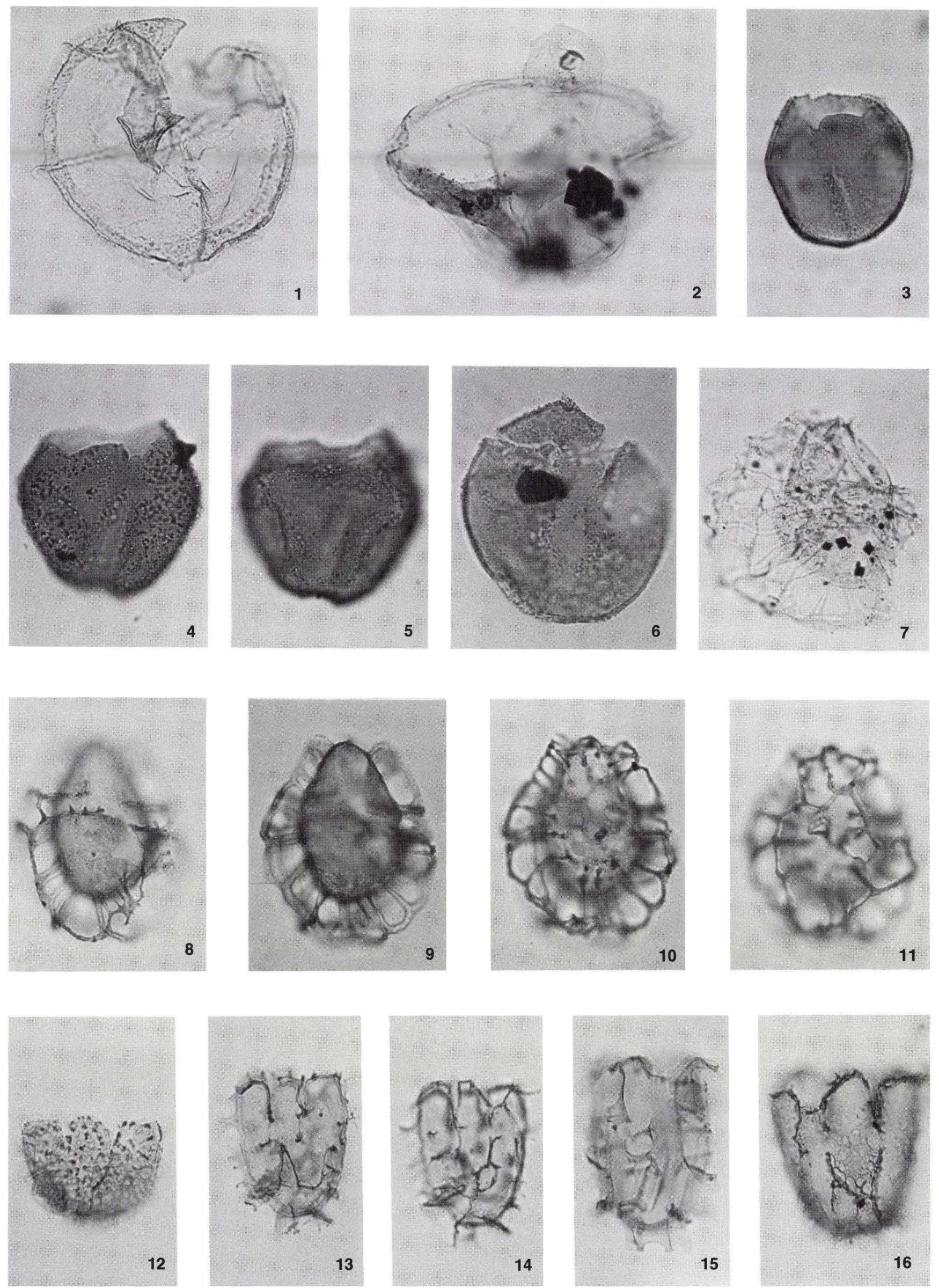
Plate 9

All magnifications $\times 500$.

Muderongia sp. A sensu Davey

Figs. 1-3. Slide SAL 5254/1, Bed 1 (Casey 1973), Spilsby Sandstone; Portlandian ("giganteus" Zone); Nettleton Top Barn Pit, Lincolnshire. 1, note irregular shape of the inner body. 2 , dorsal view; note paratabulation. 3 , ventral view.

Muderongia simplex subsp. microperforata subsp. nov.

Figs. 4, 5. Slide SAL 4637/III, type. Complete specimen.

Fig. 6. Slide SAL 4637/III, Haldager No. 1 borehole, core depth 2832 '-42'; early Valanginian - late Ryazanian, Denmark. Note numerous, clearly defined perforations of the periphragm.

Spiniferites ramosus subsp. primaevus Duxbury

Figs. 7, 8. Slide SAL 4629/3, Haldager No. 1 borehole, core depth $2545^{\prime}-65^{\prime}$; Hauterivian, Denmark. 7, detail of process terminations.

Spiniferites ramosus (Ehrenberg) Loeblich \& Loeblich group Fig. 9. Slide Sp. "Upper D4"/I', Bed D4, Speeton Clay; early Valanginian; Speeton, Yorkshire.

Dichadogonyaulax pannea (Norris) Sarjeant

Fig. 10. Slide SAL 5025/2, Haldager No. 1 borehole, core depth $3180^{\prime}-90^{\prime}$; Portlandian, Denmark. Note posterior paracingular crest. Interference contrast.

Scriniodinium campanulum Gocht

Figs. 11, 12. Slide SAL 4629/4, Haldager No. 1 borehole, core depth 2545'-65'; Hauterivian, Denmark. 11, dorsal view. 12, ventral view.

Occisucysta tentoria Duxbury

Figs. 13, 14. Slide Sp. C11B/1, Bed C11, Speeton Clay; Hauterivian; Speeton, Yorkshire. 
Plate 9
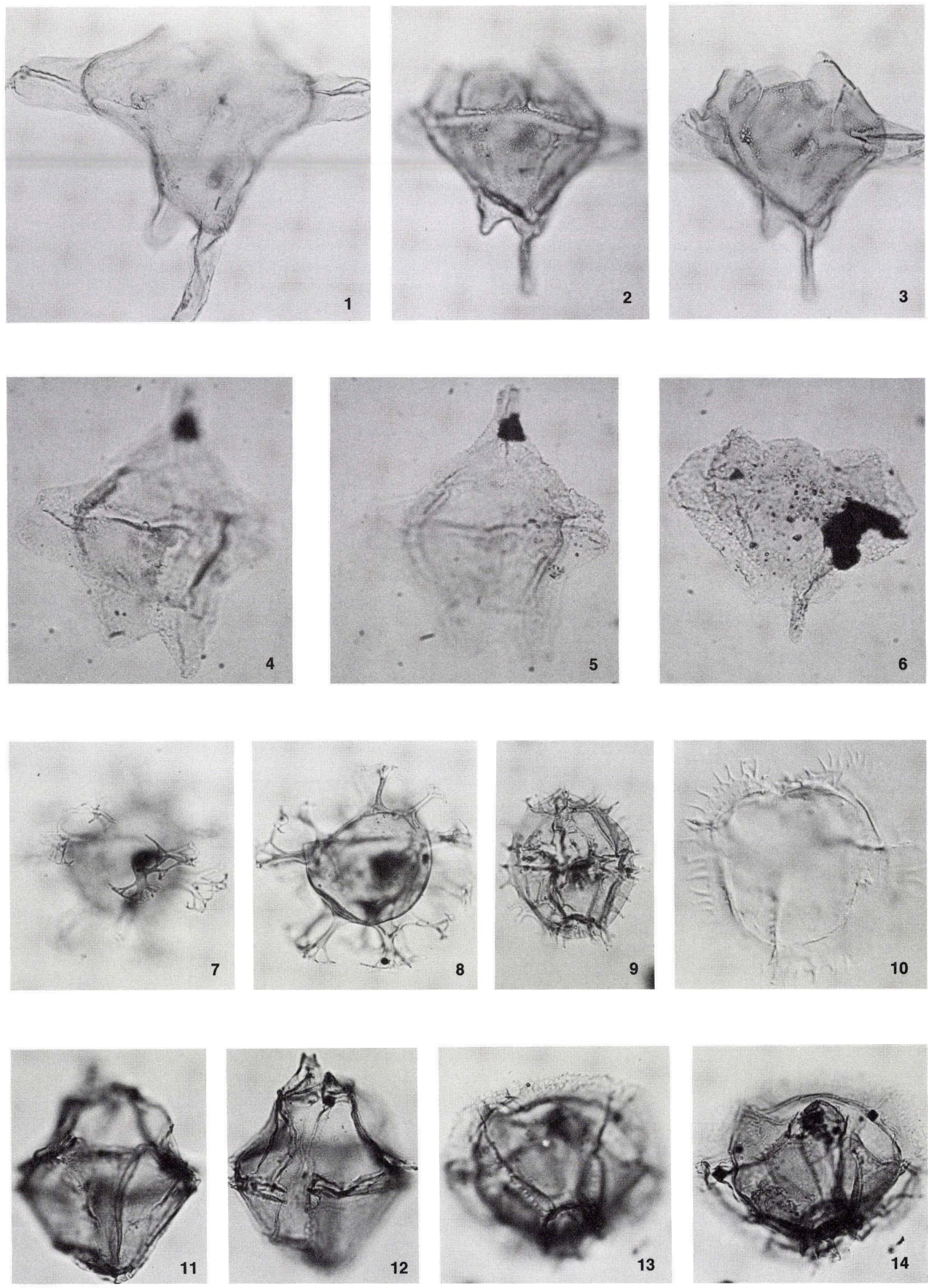
Plate 10

All magnifications $\times 500$ unless otherwise stated.

Egmontodinium ovatum (Gitmez \& Sarjeant) Riley

Figs. 1, 2. Slide GH 4/1, Kimmeridge Clay Formation; Kimmeridgian (pectinatus Zone); Golden Hill Pit, Yorkshire. 1, enlargement $(\times 1500)$ to show process terminations; phase contrast.

Gonyaulacysta sp. A Davey

Fig. 3. Slide SAL 4639/II, Haldager No. 1 borehole, core depth 2896'-2915'; Ryazanian, Denmark.

Hystrichosphaeridium cf. recurvatum (White) Davey \& Williams Fig. 4. Slide SAL 4629/I, Haldager No. 1 borehole, core depth $2545^{\prime}-65^{\prime}$; Hauterivian, Denmark.

\section{Cribroperidinium sp. A}

Figs. 5, 6. Slide SAL 5254/3, Bed 1 (Casey 1973), Spilsby Sandstone; Portlandian ("giganteus" Zone); Nettleton Top Barn Pit, Lincolnshire. 5, detail of apical horn. 6, medial view.

Hystrichogonyaulax cf. cladophora (Deflandre) Stover \& Evitt Fig. 7. Slide SAL 4628/I, Haldager No. 1 borehole, core depth $2505^{\prime}-25^{\prime}$; Hauterivian, Denmark.
Kleithriasphaeridium porosispinum sp. nov.

Fig. 8. Slide SAL 5254/3, Bed 1 (Casey 1973), Spilsby Sandstone; Portlandian ("giganteus" Zone); Nettleton Top Barn Pit, Lincolnshire. Note large precingular archaeopyle.

Fig. 9. Slide SAL 4639/II, Haldager No. 1 borehole, core depth $2896^{\prime}-2915^{\prime}$; Ryazanian, Denmark. Note fibrous/perforate nature of process. $\times 1500$, phase contrast.

Figs. 10-12. Slide GB 424/2, holotype.

? Maduradinium sp. A Davey

Fig. 13. Slide SAL 4629/4, Haldager No. 1 borehole, core depth 2545'-65'; Hauterivian, Denmark. Note granular apical, antapical and paracingular regions.

Occisucysta sp. A Davey

Fig. 14. Slide SAL 4634/III, Haldager No. 1 borehole, core depth $2752^{\prime}-62^{\prime}$; early Valanginian, Denmark. Dorsal view showing $2 \mathrm{P}$ archaeopyle.

Fig. 15. Slide SAL 4637/IV, Haldager No. 1 borehole, core depth 2832 -42'; early Valanginian - late Ryazanian, Denmark. Lateral view showing well developed parasutural crests and intratabular ornamentation.

Pseudoceratium pelliferum Gocht

Fig. 16. Slide SAL 4636/I, Haldager No. 1 borehole, core depth $2822^{\prime}-32^{\prime}$; early Valanginian - late Ryazanian, Denmark. Note the wide body and short horns of this early representative of this species. Phase contrast. 
Plate 10
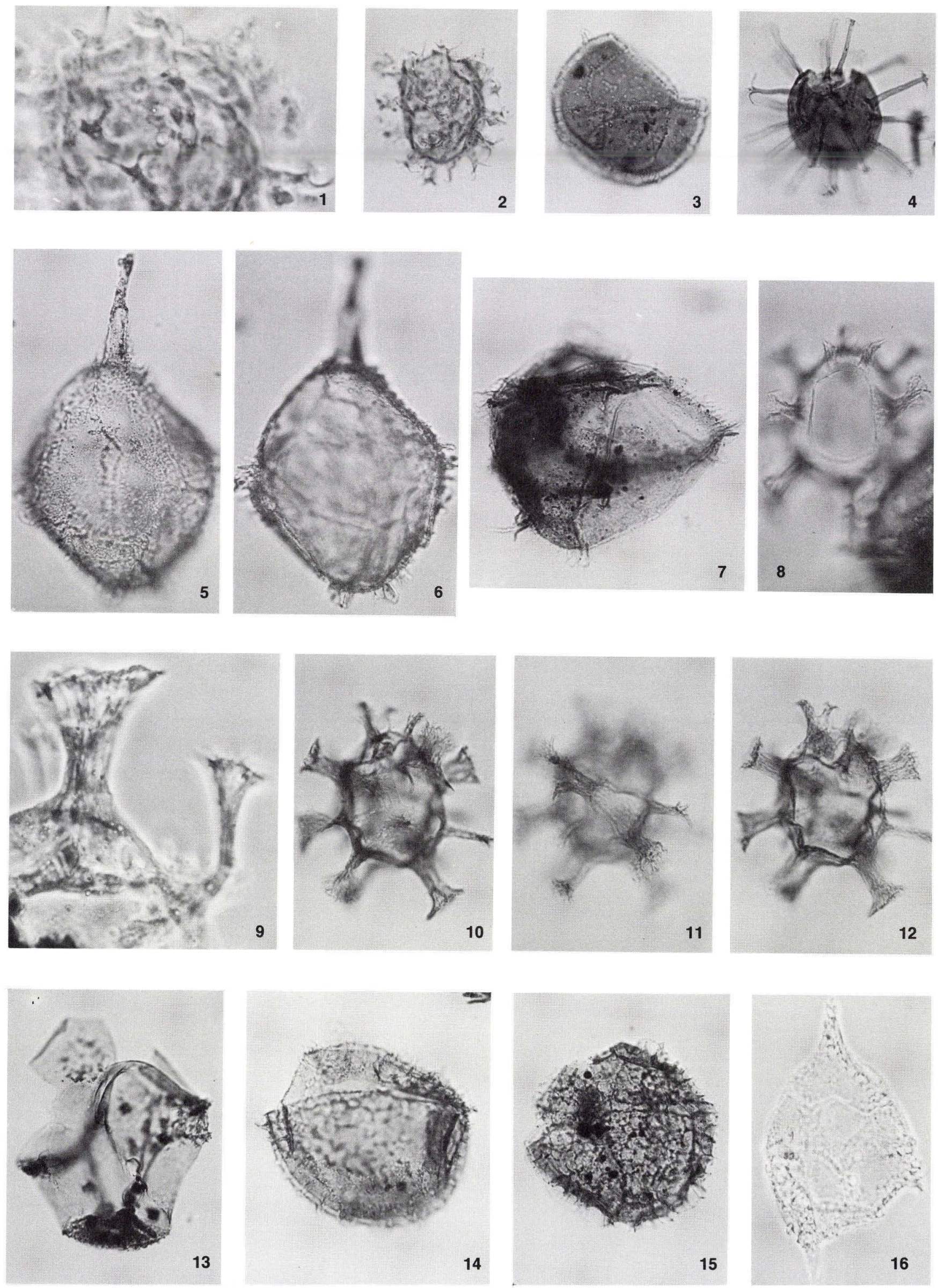